Supporting Information For:

Synthesis, Characterization, and Electrochemistry of the Homoleptic f Element Ketimide Complexes, $[\mathrm{Li}]_{2}\left[\mathrm{M}\left(\mathrm{N}=\mathrm{C}^{t} \mathrm{BuPh}\right)_{6}\right](\mathrm{M}=\mathrm{Ce}, \mathrm{Th})$

Mikiyas K. Assefa, Dumitru-Claudiu Sergentu, Lani A. Seaman, Guang Wu, Jochen Autschbach*, and Trevor W. Hayton*

Department of Chemistry and Biochemistry, University of California Santa Barbara, Santa Barbara, CA 93106, USA

Department of Chemistry, University at Buffalo, State University of New York, 312 Natural Sciences Complex, Buffalo, USA

*To whom correspondence should be addressed. Email: hayton@chem.ucsb.edu, jochena@buffalo.edu 


\section{Table of Contents}

$\begin{array}{ll}\text { Experimental Details } & \text { S3 }\end{array}$

$\begin{array}{ll}\text { NMR Spectra } & \text { S9 }\end{array}$

$\begin{array}{ll}\text { X-Ray Crystallographic Details } & \text { S35 }\end{array}$

$\begin{array}{ll}\text { IR Spectra } & \text { S35 }\end{array}$

$\begin{array}{ll}\text { Cyclic Voltammetry } & \text { S37 }\end{array}$

$\begin{array}{ll}\text { Magnetism } & \text { S42 }\end{array}$

$\begin{array}{ll}\text { Computational Analysis } & \text { S46 }\end{array}$

$\begin{array}{ll}\text { References } & \text { S54 }\end{array}$ 


\section{Experimental}

General Procedures. All reactions and subsequent manipulations were performed under anaerobic and anhydrous conditions in the glovebox or on a Schlenk line, under an atmosphere of dinitrogen. Hexanes, diethyl ether $\left(\mathrm{Et}_{2} \mathrm{O}\right)$, and toluene were dried by passage over activated molecular sieves using a Vacuum Atmospheres solvent purification system. Tetrahydrofuran (THF) was distilled over Na/benzophenone and stored over activated $3 \AA$ molecular sieves for 24 h prior to use. $\mathrm{C}_{6} \mathrm{D}_{6}$ was dried over activated $3 \AA$ molecular sieves for $24 \mathrm{~h}$ prior to use. $\left[\mathrm{Ce}\left(\mathrm{NO}_{3}\right)_{3}(\mathrm{THF})_{4}\right],{ }^{1}\left[\mathrm{ThCl}_{4}(\mathrm{DME})_{2}\right],{ }^{2}$ and $\mathrm{Li}\left(\mathrm{N}=\mathrm{C}{ }^{t} \mathrm{BuPh}\right)^{3}$ were prepared according to the reported literature procedures. All other reagents were purchased from commercial suppliers and used as received.

${ }^{1} \mathrm{H},{ }^{13} \mathrm{C}\left\{{ }^{1} \mathrm{H}\right\}$, and ${ }^{7} \mathrm{Li}\left\{{ }^{1} \mathrm{H}\right\}$ NMR spectra were recorded on an Agilent Technologies $400 \mathrm{MHz}$ 400-MR DD2. ${ }^{1} \mathrm{H}$ and ${ }^{13} \mathrm{C}\left\{{ }^{1} \mathrm{H}\right\}$ NMR spectra were referenced to external $\mathrm{SiMe}_{4}$ using residual protio solvent resonances as internal standards. ${ }^{7} \mathrm{Li}\left\{{ }^{1} \mathrm{H}\right\}$ NMR spectra were referenced indirectly with the ${ }^{1} \mathrm{H}$ chemical shift of $\mathrm{SiMe}_{4}$ at 0 ppm, according to IUPAC standard. ${ }^{4,5}$ IR spectra were recorded on a Nicolet 6700 FT-IR spectrometer. Electronic absorption spectra were recorded on a Shimadzu UV3600 UV-NIR Spectrometer. Elemental analyses were performed by the Microanalytical Laboratory at University of California (Berkeley, CA).

X-ray Crystallography. Data for $\mathbf{1}$ and $\mathbf{2}$ were collected on a Bruker KAPPA APEX II diffractometer equipped with an APEX II CCD detector using a TRIUMPH monochromater with a Mo K $\alpha$ X-ray source $(\alpha=0.71073 \AA)$. The crystals of 1 and 2 were mounted on a cryoloop under Paratone-N oil, and all data were collected at 100(2) K using an Oxford nitrogen gas cryostream system. X-ray data for 1 and $\mathbf{2}$ were collected utilizing frame exposures of 15 and $5 \mathrm{~s}$, respectively. Data collection and cell parameter determinations were conducted using the 
SMART program. ${ }^{6}$ Integration of the data frames and final cell parameter refinement were performed using SAINT software. ${ }^{7}$ Absorption corrections of the data were carried out using the multi-scan method SADABS. ${ }^{8}$ Subsequent calculations were carried out using SHELXTL. .9 Structure determination was done using direct or Patterson methods and difference Fourier techniques. All hydrogen atom positions were idealized, and rode on the atom of attachment. Structure solution, refinement, graphics, and creation of publication materials were performed using SHELXTL. ${ }^{9}$

Cyclic Voltammetry Measurements. CV experiments were performed with a CH Instruments 600c Potentiostat, and the data were processed using CHI software (version 6.29). All experiments were performed in a glove box using a $20 \mathrm{~mL}$ glass vial as the cell. The working electrode was glassy carbon ( $3 \mathrm{~mm}$ diameter), the counter electrode was a platinum wire, and the reference electrode was a silver wire electroplated with silver chloride. Solutions employed for CV studies were typically $1 \mathrm{mM}$ in analyte and $0.1 \mathrm{M}$ in [NBu4][BPh4]. All potentials are reported versus the $\left[\mathrm{Cp}_{2} \mathrm{Fe}\right]^{0 /+}$ couple using $\mathrm{Cp}_{2} \mathrm{Co}\left(-1.31 \mathrm{~V} \mathrm{vs} \mathrm{Fc} / \mathrm{Fc}^{+}\right)$as an internal standard.

Magnetic Susceptibility. Magnetic measurements were made using a 7 T Quantum Design MPMS 3 SQUID magnetometer. All loading equipment, including quartz wool and quartz tubes, were oven-dried at $120^{\circ} \mathrm{C}$ for several days prior to use. Complex $1(32.7 \mathrm{mg}, 0.029 \mathrm{mmol})$ was sandwiched between high purity quartz wool $(32.6 \mathrm{mg}$ total) in a $5 \mathrm{~mm}$ quartz tube that was flame-sealed at one end, and tightly packed to a length of $\sim 2 \mathrm{~cm}$. Latex gloves were worn over glovebox gloves during sample loading, and contact with quartz wool was minimized to prevent contamination. A vacuum adaptor was attached to the open end of the quartz tube, and the sample was subsequently flame-sealed under static vacuum. The susceptibility data were corrected for diamagnetic contributions of the ligands using Pascal constants. ${ }^{10}$ No correction 
was applied to account for the contribution of the quartz tube or quartz wool to the overall sample susceptibility.

Synthesis of $[\mathbf{L i}]_{2}\left[\mathbf{C e}\left(\mathbf{N}=\mathbf{C}^{t} \mathbf{B u P h}\right)_{6}\right](\mathbf{1})$ : To a stirring, colorless solution of $\left[\mathrm{Ce}\left(\mathrm{NO}_{3}\right)_{3}(\mathrm{THF})_{4}\right]$ $(152.0 \mathrm{mg}, 0.247 \mathrm{mmol})$ in THF $(1 \mathrm{~mL})$ was added a yellow solution of $\mathrm{Li}\left(\mathrm{N}=\mathrm{C}^{t} \mathrm{BuPh}\right)(247.7$ $\mathrm{mg}, 1.483 \mathrm{mmol})$ in THF $(1 \mathrm{~mL})$. This addition resulted in an immediate color change to deep red-brown. The mixture was allowed to stir for $90 \mathrm{~min}$ at room temperature, whereupon an orange solution of $\mathrm{I}_{2}(31.0 \mathrm{mg}, 0.122 \mathrm{mmol})$ in THF $(1 \mathrm{~mL})$ was added dropwise. This addition resulted in an immediate color change to deep purple. The resulting purple mixture was then stirred for a further $15 \mathrm{~min}$. The volatiles were removed in vacuo and the resulting purple oil was triturated with pentane $(3 \times 2 \mathrm{~mL})$ to yield a purple powder. The powder was washed with pentane $(4 \mathrm{~mL})$ and the dark brown washings were discarded. The remaining residue was then extracted into $\mathrm{Et}_{2} \mathrm{O}(6 \mathrm{~mL})$ and filtered through a Celite column supported on glass wool $(0.5 \mathrm{~cm}$ $\times 2 \mathrm{~cm}$ ) to yield a purple filtrate. The filtrate was concentrated to $\sim 2 \mathrm{~mL}$ and subsequently stored at $-25^{\circ} \mathrm{C}$ for $24 \mathrm{~h}$, which resulted in deposition of purple plates. The crystals were then washed with pentane $(3 \times 2 \mathrm{~mL})$ and dried in vacuo $(68.8 \mathrm{mg})$. Concentration of the supernatant, followed by layering with equal volume of hexanes, and subsequent storage of this solution at $25^{\circ} \mathrm{C}$ for $24 \mathrm{~h}$, resulted in deposition of a second crop of purple plates. These crystals were also washed with pentane $(3 \times 2 \mathrm{~mL})$ and subsequently dried in vacuo (Total: $122.0 \mathrm{mg}, 44 \%$ yield). Anal. Calcd for $\mathrm{C}_{66} \mathrm{H}_{84} \mathrm{CeLi}_{2} \mathrm{~N}_{6}$ : C, 71.07; H, 7.59; N, 7.53. Found: C, 70.73; H, 7.64; N, 7.59. ${ }^{1} \mathrm{H}$ NMR ( $\left.\mathrm{C}_{6} \mathrm{D}_{6}, 25^{\circ} \mathrm{C}, 400 \mathrm{MHz}\right): \delta 1.36\left(\mathrm{~s}, 54 \mathrm{H}, \mathrm{CCH}_{3}\right), 6.62(\mathrm{~m}, 12 \mathrm{H}, \mathrm{o}$-aryl $\mathrm{CH}), 6.99(\mathrm{~m}$, 18H, overlapping peaks for $m$ - and $p$ - aryl $\mathrm{CH}$ ). ${ }^{1} \mathrm{H}$ NMR (Tol- $d_{8}, 25^{\circ} \mathrm{C}, 400 \mathrm{MHz}$ ): $\delta 1.32(\mathrm{~s}$, $\left.54 \mathrm{H}, \mathrm{CCH}_{3}\right), 6.56(\mathrm{~m}, 12 \mathrm{H}, \mathrm{o}$-aryl $\mathrm{CH}), 6.98(\mathrm{~m}, 18 \mathrm{H}$, overlapping peaks for $m$ - and $p$ - aryl $\mathrm{CH})$. ${ }^{1} \mathrm{H}$ NMR (THF- $\left.d 8,25^{\circ} \mathrm{C}, 400 \mathrm{MHz}\right): \delta 1.00$ (s, 9H, $\left.\mathrm{CCH}_{3}, \mathrm{Li}\left(\mathrm{N}=\mathrm{C}{ }^{\prime} \mathrm{BuPh}\right)\right), 1.06$ (s, 45H, $\mathrm{CCH}_{3}$, 
$\left.[\mathrm{Li}]\left[\mathrm{Ce}\left(\mathrm{N}=\mathrm{C}^{t} \mathrm{BuPh}\right)_{5}\right]\right), 7.02(\mathrm{~m}, 12 \mathrm{H}, o$-aryl $\mathrm{CH}), 7.12(\mathrm{~m}, 18 \mathrm{H}$, overlapping peaks for $m$ - and $p$ $\operatorname{aryl} \mathrm{CH}) .{ }^{13} \mathrm{C}\left\{{ }^{1} \mathrm{H}\right\}$ NMR $\left(\mathrm{C}_{6} \mathrm{D}_{6}, 25{ }^{\circ} \mathrm{C}, 100 \mathrm{MHz}\right): \delta 29.15\left(\mathrm{CCH}_{3}\right), 45.37\left(\mathrm{CCH}_{3}\right), 125.84(p-$ aryl $\mathrm{CH}), 126.16(o$-aryl $\mathrm{CH}), 128.90(m$-aryl $\mathrm{CH}), 149.40$ (ipso-aryl $C), 175.08(\mathrm{NC}) .{ }^{7} \mathrm{Li}\left\{{ }^{1} \mathrm{H}\right\}$ NMR $\left(\mathrm{C}_{6} \mathrm{D}_{6}, 25^{\circ} \mathrm{C}, 155 \mathrm{MHz}\right): \delta 0.06$ (s, 2Li). ${ }^{7} \mathrm{Li}\left\{{ }^{1} \mathrm{H}\right\}$ NMR (Tol- $\left.d_{8}, 25{ }^{\circ} \mathrm{C}, 155 \mathrm{MHz}\right): \delta-0.02$ (s, 2Li). ${ }^{7} \mathrm{Li}\left\{{ }^{1} \mathrm{H}\right\}$ NMR $\left(\mathrm{THF}-\mathrm{d}_{8}, 25^{\circ} \mathrm{C}, 155 \mathrm{MHz}\right): \delta 0.65$ (s, [Li] $\left.\left[\mathrm{Ce}\left(\mathrm{N}=\mathrm{C}^{t} \mathrm{BuPh}\right) 5\right]\right), 1.75(\mathrm{~s}$, $\left.\mathrm{Li}\left(\mathrm{N}=\mathrm{C}^{t} \mathrm{BuPh}\right)\right), 1.94\left(\mathrm{~s}, \mathrm{Li}\left(\mathrm{N}=\mathrm{C}^{t} \mathrm{BuPh}\right)\right) . \mathrm{UV}-\mathrm{V}$ is (Toluene, $\left.0.089 \mathrm{mM}, 25^{\circ} \mathrm{C}, \mathrm{M}^{-1} \cdot \mathrm{cm}^{-1}\right): 485(\varepsilon$ = 5600). IR (KBr pellet, $\left.\mathrm{cm}^{-1}\right): 3072$ (vw), 3055 (vw), 2962 (m), 2899 (w), 2864 (w), 1637 (vs, $\left.v_{\mathrm{CN}}\right), 1624\left(\mathrm{vs}, v_{\mathrm{CN}}\right), 1473(\mathrm{~m}), 1439(\mathrm{w}), 1385(\mathrm{w}), 1360(\mathrm{~m}), 1259(\mathrm{vw}), 1198(\mathrm{w}), 1188(\mathrm{~m})$, 1074 (br, vw), 1070 (w), 1024 (w), 997 (vw), 943 (s), 904 (m), 773 (s), 708 (s), 687 (m), 615 (w), $563(\mathrm{~m}), 436(\mathrm{~m})$.

Synthesis of $[\mathbf{L i}]_{2}\left[\mathbf{T h}\left(\mathbf{N}=\mathbf{C}^{t} \mathbf{B u P h}\right)_{6}\right]$ (2): To a stirring, colorless solution of $\left[\mathrm{ThCl}_{4}(\mathrm{DME})_{2}\right]$ $(121.5 \mathrm{mg}, 0.219 \mathrm{mmol})$ in THF $(1 \mathrm{~mL})$ was added a yellow solution of $\mathrm{Li}\left(\mathrm{N}=\mathrm{C}{ }^{t} \mathrm{BuPh}\right)(220.0$ $\mathrm{mg}, 1.316 \mathrm{mmol})$ in THF $(1 \mathrm{~mL})$. The resulting yellow solution was allowed to stir for $2 \mathrm{~h}$ at room temperature. The solvent was then removed in vacuo to yield a bright yellow solid, which was extracted into 3:1 hexanes/THF $(4 \mathrm{~mL})$ and filtered through a Celite column supported on glass wool $(0.5 \mathrm{~cm} \times 2 \mathrm{~cm})$. The filtrate was concentrated to $\sim 2 \mathrm{~mL}$ and subsequently stored at $25{ }^{\circ} \mathrm{C}$ for $72 \mathrm{~h}$, which resulted in deposition of yellow blocks (139.2 mg, 53\% yield). X-ray quality crystals were obtained from a concentrated toluene solution stored at $-25^{\circ} \mathrm{C}$ for $24 \mathrm{~h}$. Anal. Calcd for $\mathrm{C}_{66} \mathrm{H}_{84} \mathrm{Li}_{2} \mathrm{~N}_{6} \mathrm{Th}: \mathrm{C}, 65.66 ; \mathrm{H}, 7.01 ; \mathrm{N}$, 6.96. Found: C, 65.64; H, 6.85; N, 7.10. ${ }^{1} \mathrm{H}$ NMR $\left(\mathrm{C}_{6} \mathrm{D}_{6}, 25^{\circ} \mathrm{C}, 400 \mathrm{MHz}\right): \delta 1.27\left(\mathrm{~s}, 54 \mathrm{H}, \mathrm{CCH}_{3}\right), 6.67(\mathrm{~m}, 12 \mathrm{H}$, o-aryl $\mathrm{CH}), 7.00(\mathrm{~m}$, 18H, overlapping peaks for $m$ - and $p$ - aryl $\mathrm{CH}$ ). ${ }^{1} \mathrm{H}$ NMR (Tol- $d_{8}, 25^{\circ} \mathrm{C}, 400 \mathrm{MHz}$ ): $\delta 1.24$ (s, $\left.54 \mathrm{H}, \mathrm{CCH}_{3}\right), 6.63(\mathrm{~m}, 12 \mathrm{H}, o$-aryl $\mathrm{CH}), 6.98(\mathrm{~m}, 18 \mathrm{H}$, overlapping peaks for $m$ - and $p$ - aryl $\mathrm{CH})$. ${ }^{1} \mathrm{H}$ NMR (THF- $\left.d_{8}, 25^{\circ} \mathrm{C}, 400 \mathrm{MHz}\right): \delta 1.00\left(\mathrm{~s}, 9 \mathrm{H}, \mathrm{CCH}_{3}, \mathrm{Li}\left(\mathrm{N}=\mathrm{C}{ }^{\prime} \mathrm{BuPh}\right)\right), 1.07\left(\mathrm{~s}, 54 \mathrm{H}, \mathrm{CCH}_{3}\right.$, 
2), $1.11\left(\mathrm{~s}, 45 \mathrm{H}, \mathrm{CCH}_{3},[\mathrm{Li}]\left[\mathrm{Th}\left(\mathrm{N}=\mathrm{C}^{t} \mathrm{BuPh}\right) 5\right]\right), 6.98(\mathrm{~m}, 12 \mathrm{H}, \mathrm{o}$-aryl CH, 2), $7.04(\mathrm{~m}, 10 \mathrm{H}, o-$ aryl $\left.\mathrm{CH},[\mathrm{Li}]\left[\mathrm{Th}\left(\mathrm{N}=\mathrm{C}^{t} \mathrm{BuPh}\right) 5\right]\right), 7.10(\mathrm{~m}, 18 \mathrm{H}$, overlapping peaks for $m$ - and $p$ - $\operatorname{aryl} \mathrm{CH})$. ${ }^{13} \mathrm{C}\left\{{ }^{1} \mathrm{H}\right\}$ NMR $\left(\mathrm{C}_{6} \mathrm{D}_{6}, 25{ }^{\circ} \mathrm{C}, 100 \mathrm{MHz}\right): \delta 29.22\left(\mathrm{CCH}_{3}\right), 43.13\left(\mathrm{CCH}_{3}\right), 125.84$ (p-aryl $\left.\mathrm{CH}\right)$, 126.09 (o-aryl CH), 128.79 (m-aryl CH), 148.27 (ipso-aryl C), 178.73 (NC). ${ }^{7} \mathrm{Li}\left\{{ }^{1} \mathrm{H}\right\} \mathrm{NMR}$ $\left(\mathrm{C}_{6} \mathrm{D}_{6}, 25^{\circ} \mathrm{C}, 155 \mathrm{MHz}\right): \delta 0.53$ (s, 2Li). ${ }^{7} \mathrm{Li}\left\{{ }^{1} \mathrm{H}\right\} \mathrm{NMR}\left(\mathrm{Tol}-d_{8}, 25{ }^{\circ} \mathrm{C}, 155 \mathrm{MHz}\right): \delta 0.47$ (s, 2Li). ${ }^{7} \mathrm{Li}\left\{{ }^{1} \mathrm{H}\right\}$ NMR (THF- $\left.d 8,25^{\circ} \mathrm{C}, 155 \mathrm{MHz}\right): \delta 0.04$ (s, [Li][Th(N=C $\left.\left.\left.{ }^{t} \mathrm{BuPh}\right) 5\right]\right), 0.61(\mathrm{~s}, 2 \mathrm{Li}$, 2), $1.75\left(\mathrm{~s}, \mathrm{Li}\left(\mathrm{N}=\mathrm{C}^{t} \mathrm{BuPh}\right)\right), 1.90\left(\mathrm{~s}, \mathrm{Li}\left(\mathrm{N}=\mathrm{C}^{t} \mathrm{BuPh}\right)\right)$. $\mathrm{UV}$-Vis (Toluene, $0.13 \mathrm{mM}, 25^{\circ} \mathrm{C}, \mathrm{M}^{-}$ $\left.{ }^{1} \cdot \mathrm{cm}^{-1}\right): 385(\varepsilon=1595) . \quad$ IR $\left(\mathrm{KBr}\right.$ pellet, $\left.\mathrm{cm}^{-1}\right): 3072(\mathrm{vw}), 3057(\mathrm{vw}), 3012(\mathrm{vw}), 2962(\mathrm{~m}), 2945$ (sh m), 2895 (w), 2864 (w), 1643 (vs, $v_{\mathrm{CN}}$ ), 1626 (vs, $\left.v_{\mathrm{CN}}\right), 1475$ (m), 1460 (w), 1439 (w), 1385 (w), $1360(\mathrm{~m}), 1261(\mathrm{vw}), 1215(\mathrm{w}), 1198(\mathrm{w}), 1190(\mathrm{~m}), 1070(\mathrm{w}), 1024(\mathrm{w}), 997$ (vw), $945(\mathrm{~s})$, $904(\mathrm{~m}), 773(\mathrm{~s}), 704(\mathrm{~s}), 687(\mathrm{~m}), 617(\mathrm{w}), 565(\mathrm{~m}), 438(\mathrm{~m})$.

Computational details. A series of Kohn-Sham density functional theory (DFT) and restricted/complete active space (RAS/CAS) self-consistent field ${ }^{11}$ calculations were performed on the crystal structure of $[\mathrm{Li}]_{2}\left[\mathrm{Ce}(\mathrm{N}=\mathrm{CtBuPh})_{6}\right](\mathbf{1})$ and $[\mathrm{Li}]_{2}\left[\mathrm{Th}(\mathrm{N}=\mathrm{CtBuPh})_{6}\right](\mathbf{2})$ or truncated models thereof $(\mathbf{t} 1, \mathbf{t} 2)$, depicted in Figure S35, in order to assess the ground state multiconfigurational character, ground state metal-ligand bonding, and to assign the observed lowenergy UV-vis spectrum. Ground state DFT calculations with the TPSS meta-generalized gradient approximation ${ }^{12}$ (meta-GGA) were performed with ORCA v4.1.2, ${ }^{13,14}$ using the SDD effective small-core potential ${ }^{15-18}$ for Ce and Th along with def2-TZVP (Ce, N and C), Stuttgart RSC (Th), and def2-SVP (H) valence basis sets. ${ }^{19,20}$ These calculations used the RIJ approximation with very large RIJ basis sets generated with the AutoAux procedure (automatic construction of a general purpose auxiliary basis set). ${ }^{21}$ Additionally, ground state DFT/TPSS calculations were performed with the Amsterdam Density Functional package (ADF, v2017)22 
using the all-electron scalar-relativistic zero-order regular approximation (ZORA) Hamiltoniann ${ }^{23}$ with triple- $\zeta$ doubly polarized (TZ2P) basis sets for all atoms. The extent of metal-ligand bonding was determined from the ORCA and ADF calculations via analyses of the natural localized molecular orbitals (NLMOs) generated with a locally modified version of NBO6. ${ }^{24}$

The UV-vis spectrum of $\mathbf{1}$ and $\mathbf{2}$ were simulated with time-dependent (Kohn-Sham) DFT (TD-DFT) and the Tamm-Dancoff approximation, ${ }^{25}$ using ORCA. In addition to the computational settings used for the ground state, the conductor-like polarizable continuum model $(\mathrm{CPCM})^{26,27}$ was applied to treat solvent effects (toluene). A total number of 200 spin-allowed excited states were calculated. In order to assign the absorption spectrum, calculated excited states with appreciable oscillator strength were analyzed in terms of donor-acceptor natural transition orbitals (NTO). ${ }^{28}$

Multi-configurational RAS-level calculations were performed, with OpenMolcas ${ }^{29}$ on the truncated structures $\mathbf{t} 1$ and $\mathbf{t} 2$ (Figure S35), which allowed us to exploit the $C_{\mathrm{i}}$ point group. These calculations employed the second order Douglas-Kroll-Hess (DKH2) Hamiltonian ${ }^{30-33}$ along with all-electron ANO-RCC-VTZP basis sets for all atoms and the resolution of the identity approximation (RICD) ${ }^{34}$ To aid SCF convergence, a level shift of 2.0 was applied. The RAS setup was inspired by Reference ${ }^{35}$, in which the ground state multi-configurational character was investigated for a multiply bonded Ce(IV) complex. The active space comprised twelve orbitals (the $\mathrm{N}-\mathrm{C} \sigma$ and $\pi$ bonding orbitals) with 24 electrons and at most two holes in the RAS1 subspace, twelve orbitals (the $\mathrm{N}-\mathrm{C} \sigma^{*}$ and $\pi^{*}$ antibonding orbitals) with at most two electron occupancies in the RAS3 subspace, and the seven Ce-4f/Th- 5 f orbitals with unrestricted occupations confined in the RAS2 subspace. Test calculations with the N-2p lone pairs and/or Ce-5d/Th-6d orbitals taken as active in the RAS could not be converged, suggesting that these 
orbitals are not required in the description of the ground state. Concerning the Ce-5d orbitals, similar findings were reported in Reference ${ }^{35}$. The converged RAS concluded with essentially zero occupations for the Ce-4f/Th-5f orbitals but large correlation between the N-C $\pi$ and $\pi^{*}$ orbitals in particular. Therefore, CAS $(12,12)$ calculations were also performed for $\mathbf{t} \mathbf{1}$ and $\mathbf{t} \mathbf{2}$. 


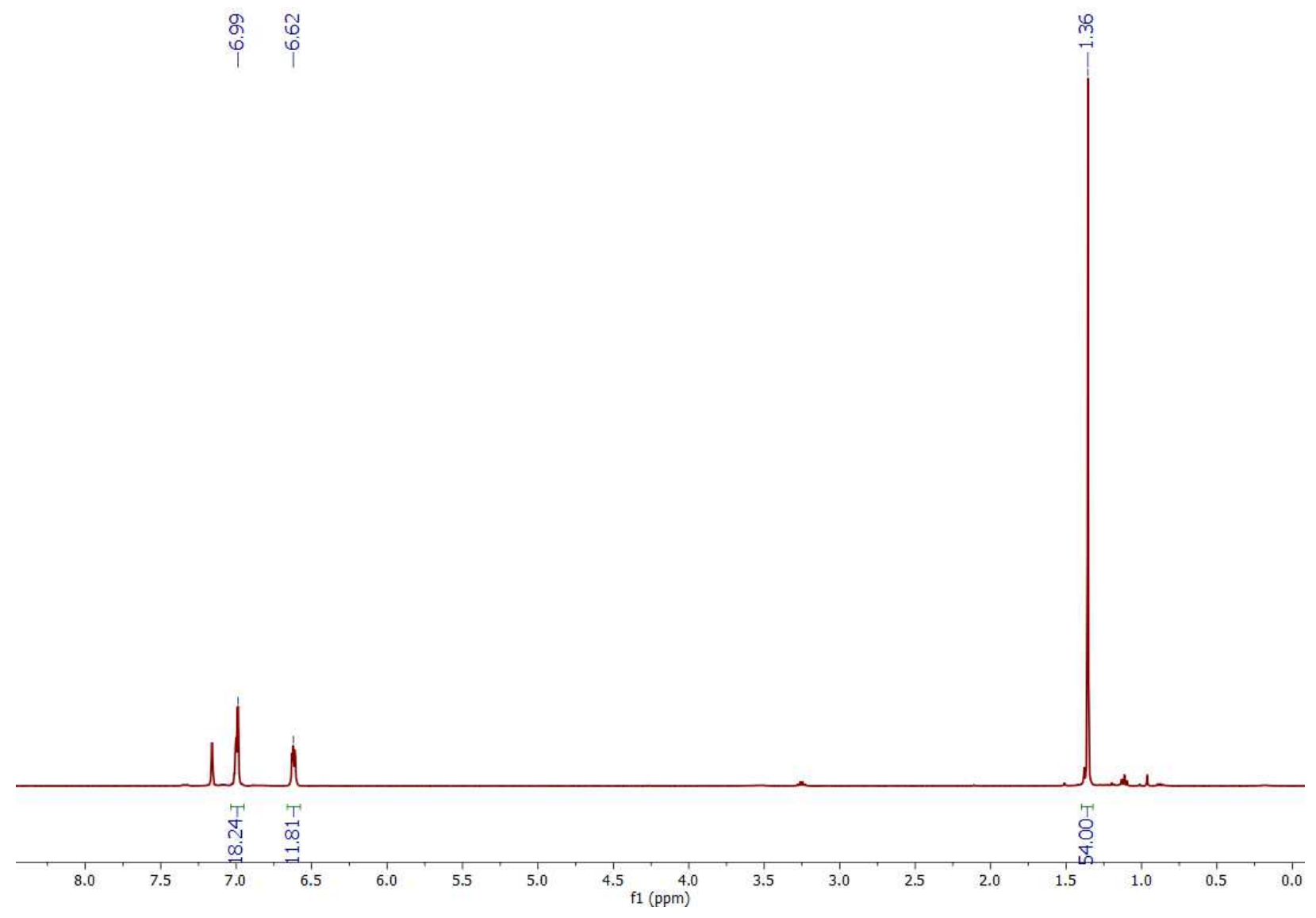

Figure S1. ${ }^{1} \mathrm{H}$ NMR spectrum of 1 in $\mathrm{C}_{6} \mathrm{D}_{6}$. 


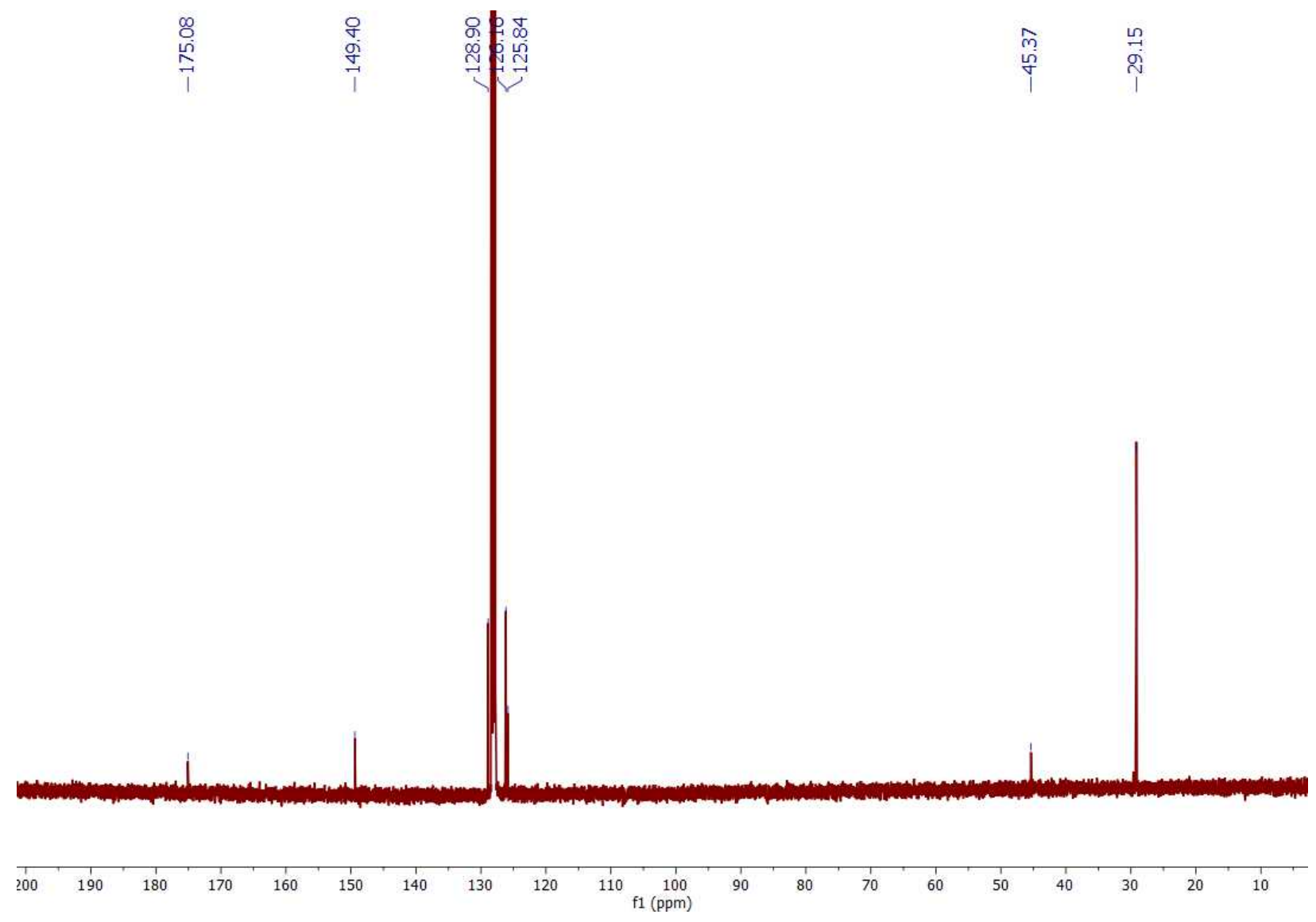

Figure S2. ${ }^{13} \mathrm{C}\left\{{ }^{1} \mathrm{H}\right\}$ NMR spectrum of $\mathbf{1}$ in $\mathrm{C}_{6} \mathrm{D}_{6}$. 


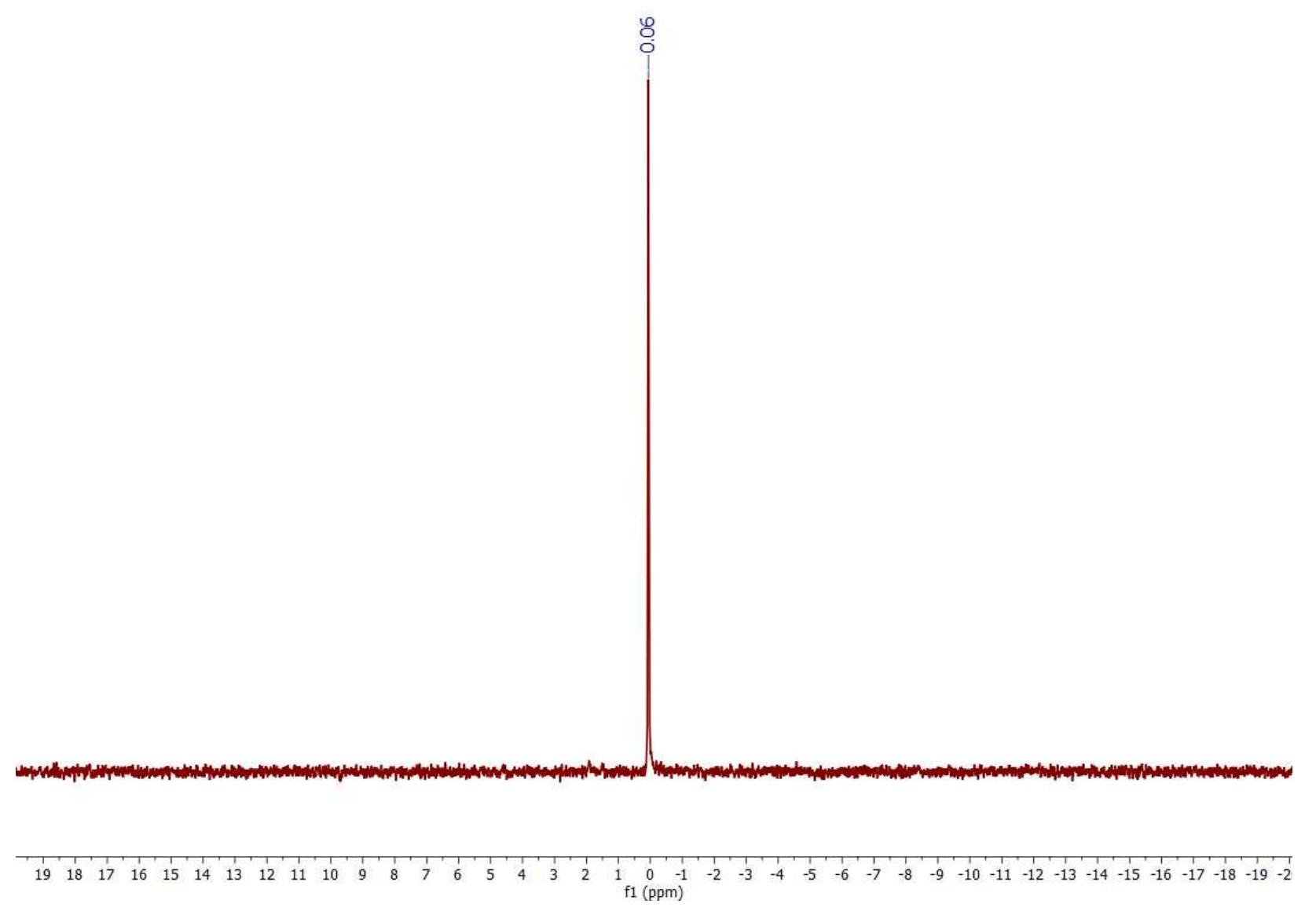

Figure S3. ${ }^{7} \mathrm{Li}\left\{{ }^{1} \mathrm{H}\right\}$ NMR spectrum of $\mathbf{1}$ in $\mathrm{C}_{6} \mathrm{D}_{6}$. 


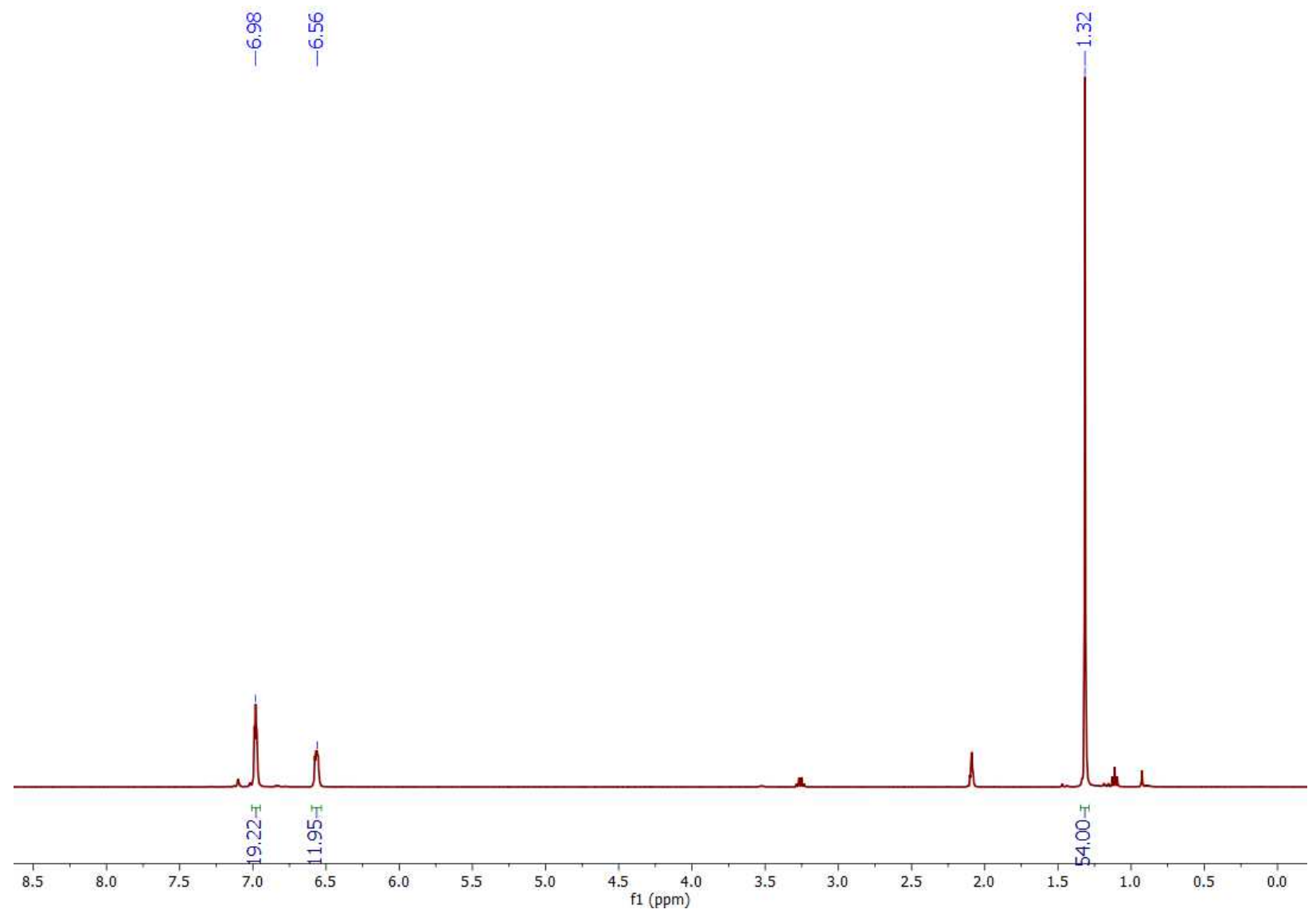

Figure S4. ${ }^{1} \mathrm{H}$ NMR spectrum of 1 in Tol-d8. 


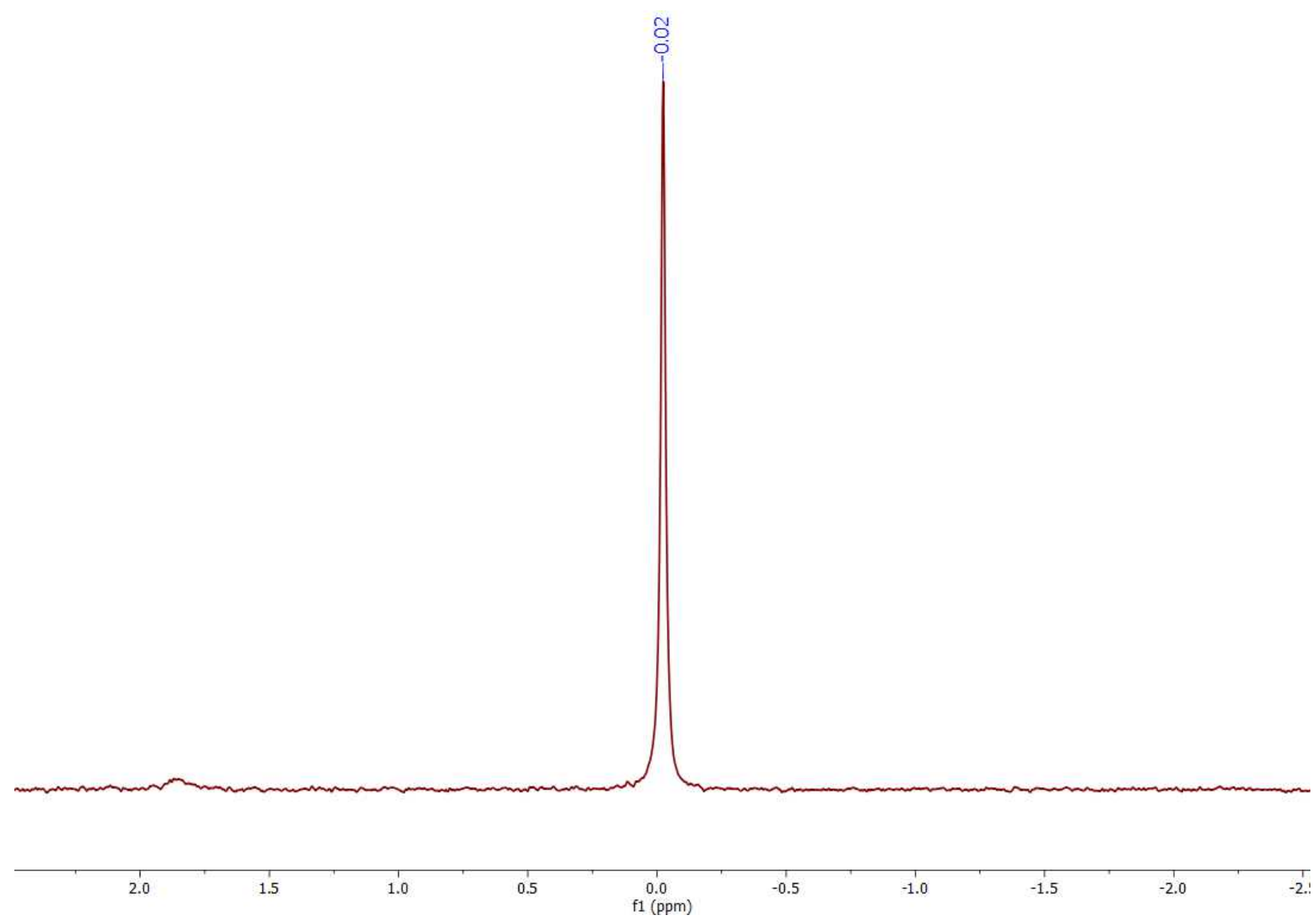

Figure S5. ${ }^{7} \mathrm{Li}\left\{{ }^{1} \mathrm{H}\right\}$ NMR spectrum of $\mathbf{1}$ in Tol- $d_{8}$. 


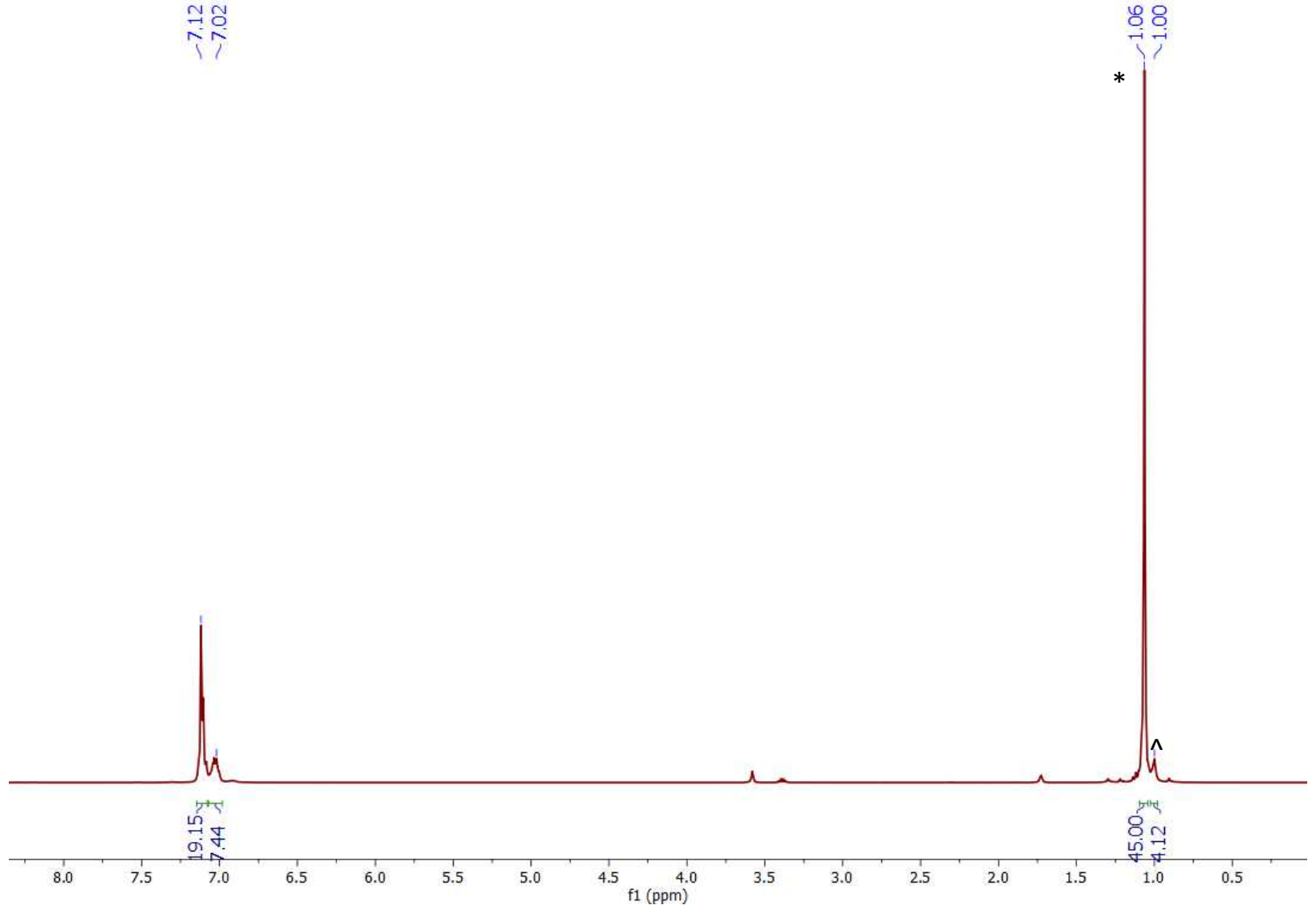

Figure S6. ${ }^{1} \mathrm{H}$ NMR spectrum of 1 in THF- $d_{8}$. The resonance marked with $*$ is assignable to $[\mathrm{Li}]\left[\mathrm{Ce}\left(\mathrm{N}=\mathrm{C}^{t} \mathrm{BuPh}\right)_{5}\right]\left(\mathbf{1}^{\prime}\right)$ and the resonance marked with ${ }^{\wedge}$ is assignable to $\mathrm{Li}\left(\mathrm{N}=\mathrm{C}^{t} \mathrm{BuPh}\right)$. 


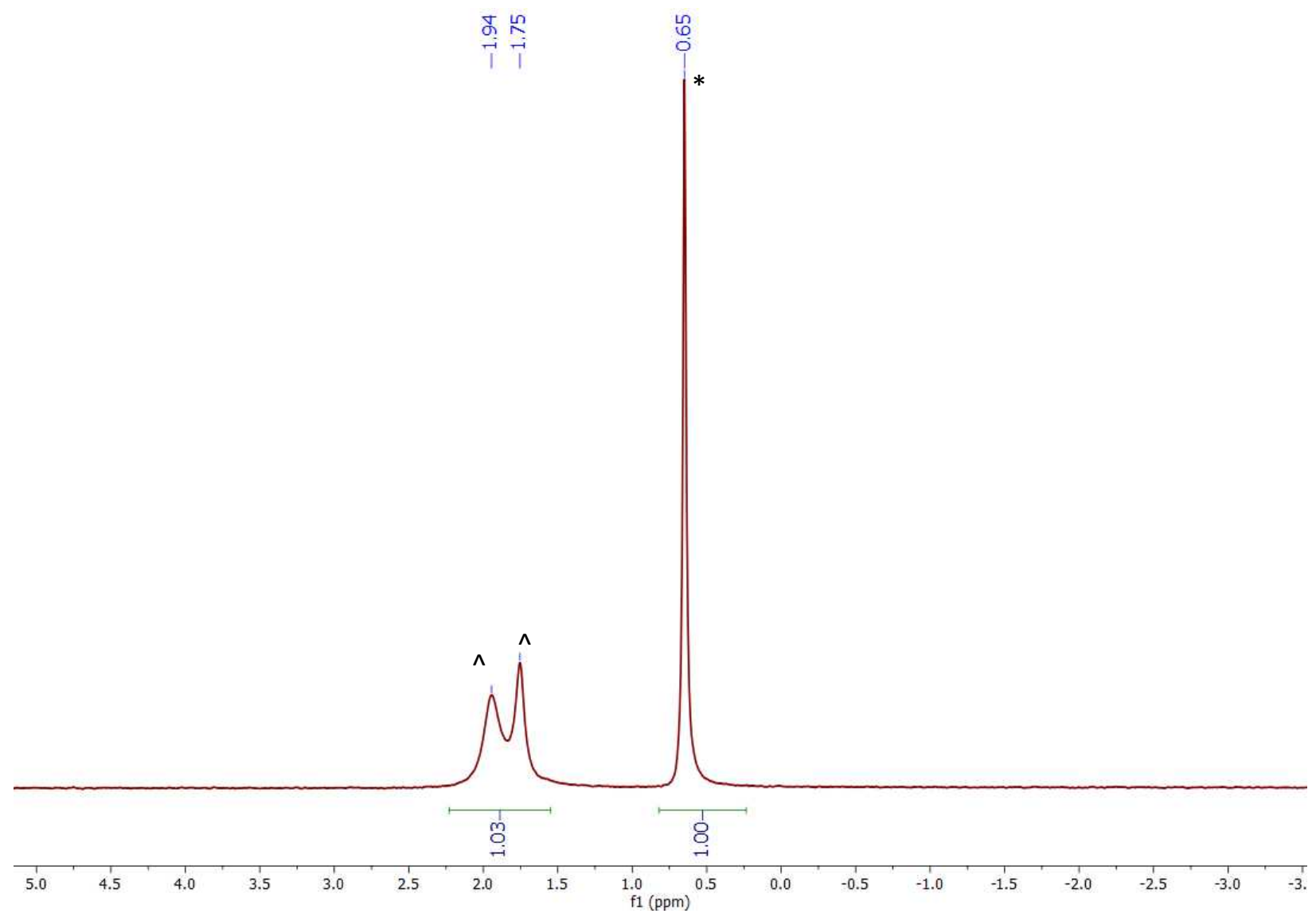

Figure S7. ${ }^{7} \mathrm{Li}\left\{{ }^{1} \mathrm{H}\right\}$ NMR spectrum of 1 in THF- $d_{8}$. The resonance marked with * is assignable to $[\mathrm{Li}]\left[\mathrm{Ce}\left(\mathrm{N}=\mathrm{C}^{t} \mathrm{BuPh}\right)_{5}\right]\left(\mathbf{1}^{\prime}\right)$ and the resonances marked with ${ }^{\wedge}$ are assignable to $\mathrm{Li}\left(\mathrm{N}=\mathrm{C}^{t} \mathrm{BuPh}\right)$. 


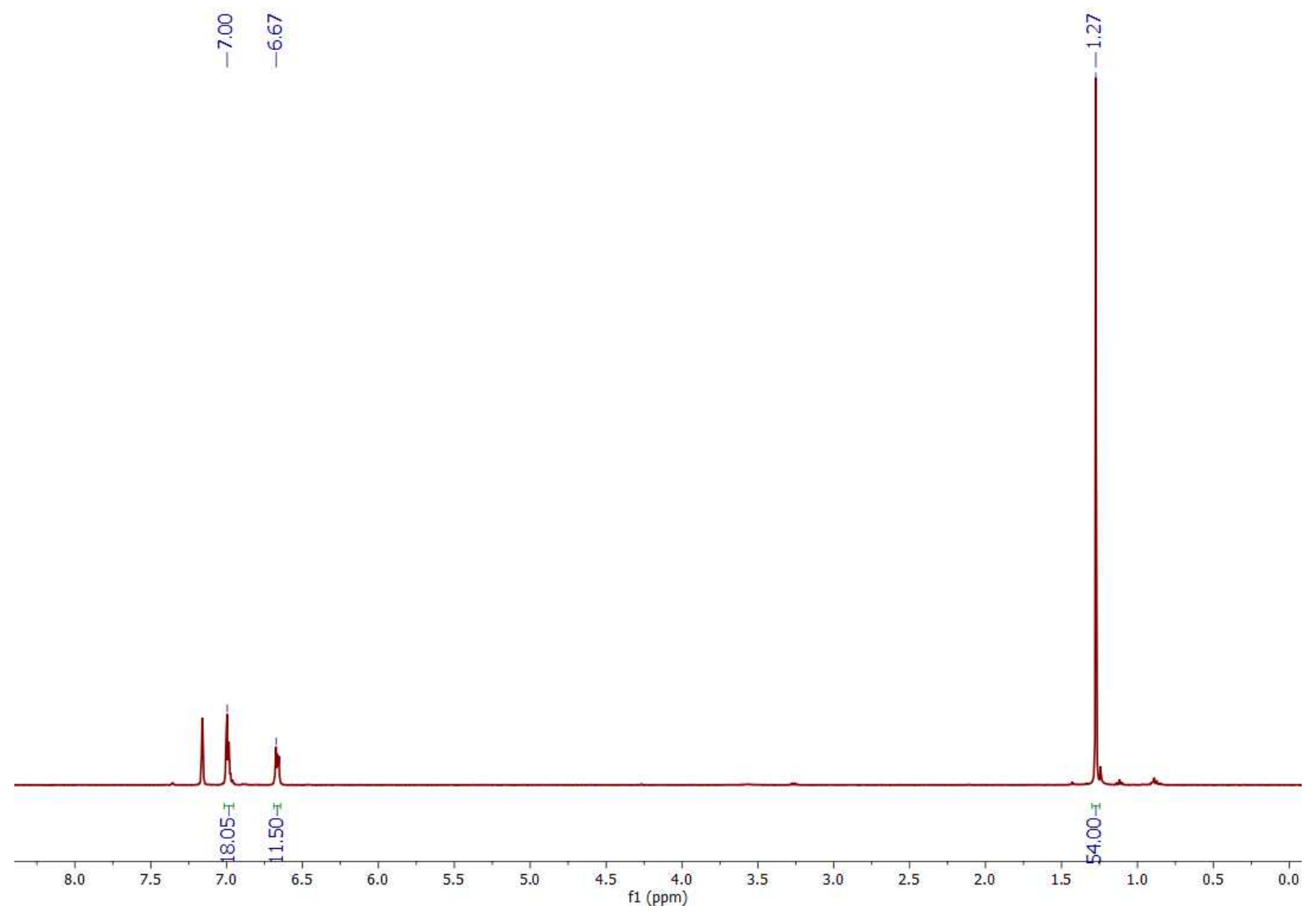

Figure S8. ${ }^{1} \mathrm{H}$ NMR spectrum of 2 in $\mathrm{C}_{6} \mathrm{D}_{6}$. 


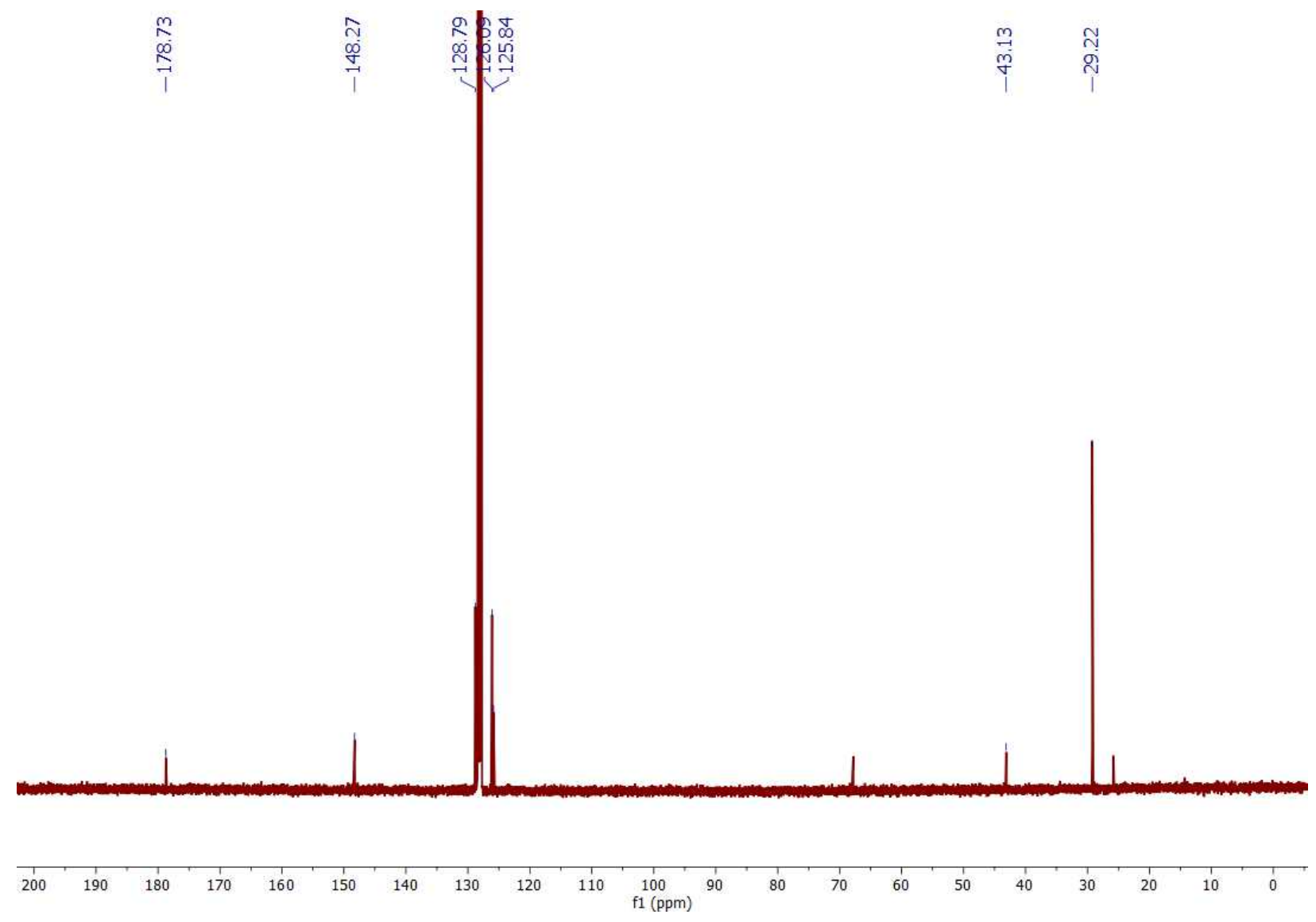

Figure S9. ${ }^{13} \mathrm{C}\left\{{ }^{1} \mathrm{H}\right\}$ NMR spectrum of 2 in $\mathrm{C}_{6} \mathrm{D}_{6}$. 


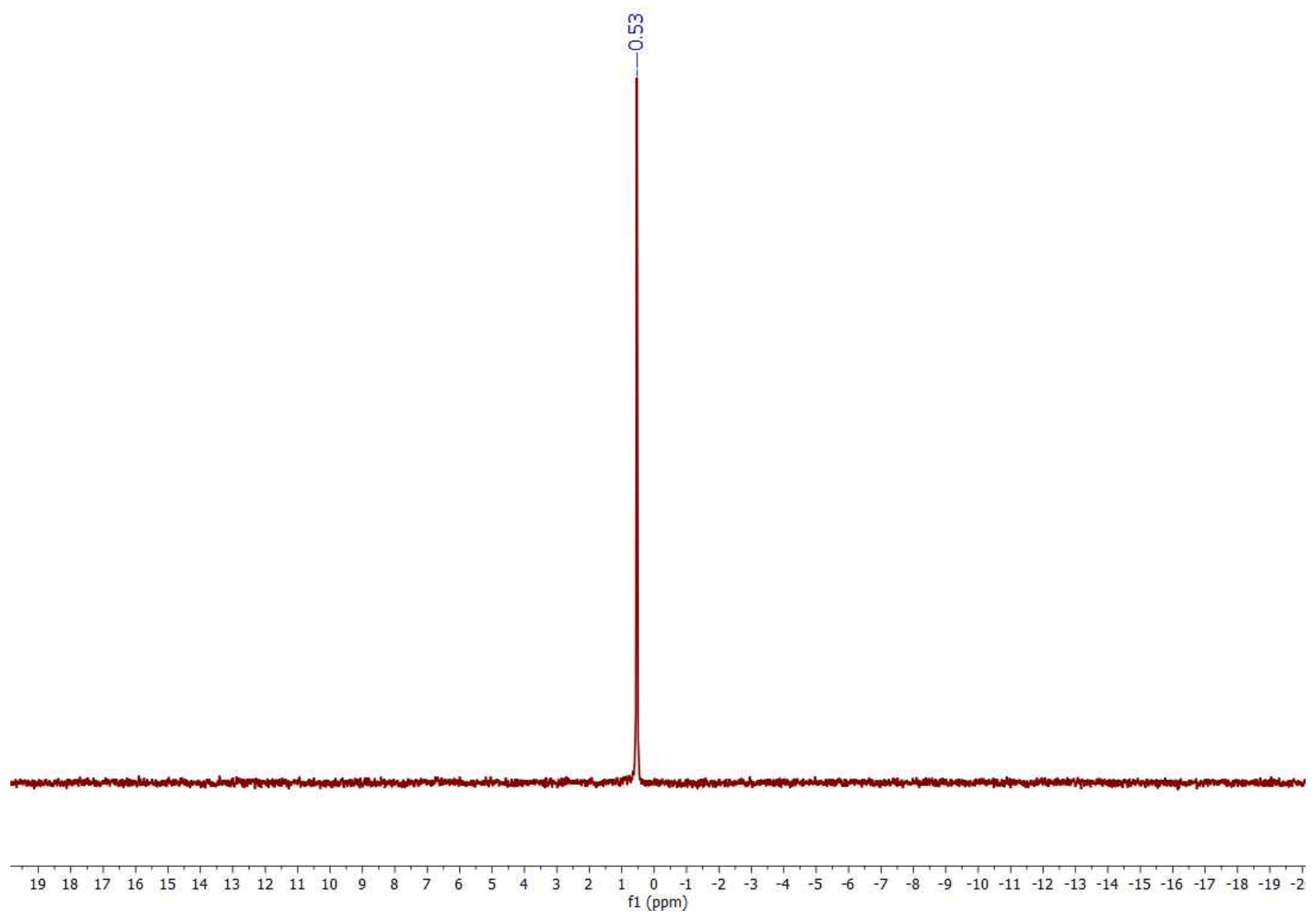

Figure S10. ${ }^{7} \mathrm{Li}\left\{{ }^{1} \mathrm{H}\right\}$ NMR spectrum of 2 in $\mathrm{C}_{6} \mathrm{D}_{6}$. 


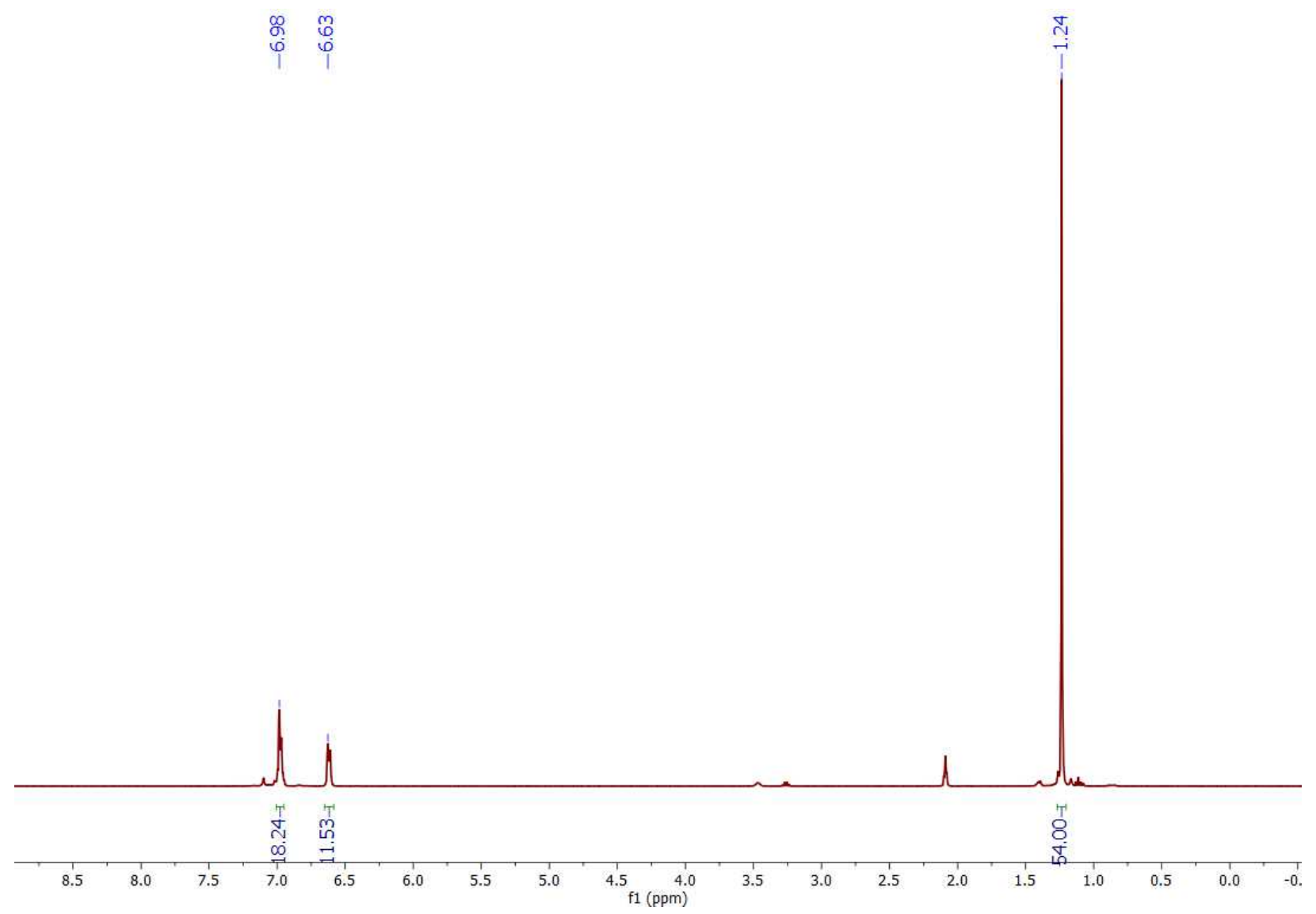

Figure S11. ${ }^{1} \mathrm{H}$ NMR spectrum of 2 in Tol- $d 8$. 


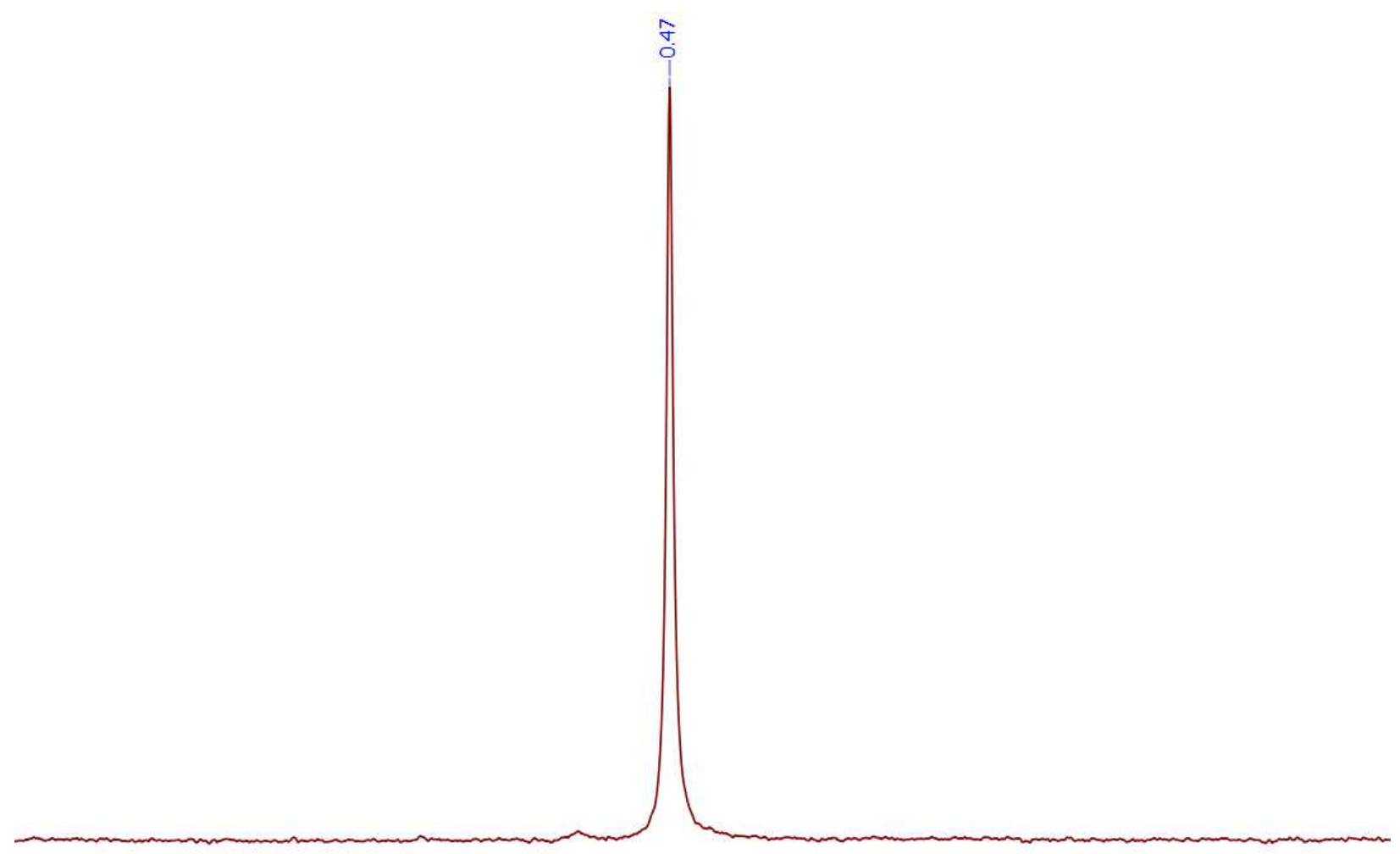

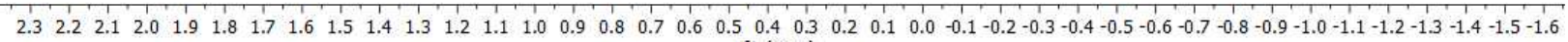
f1 (ppm)

Figure S12. ${ }^{7} \mathrm{Li}\left\{{ }^{1} \mathrm{H}\right\}$ NMR spectrum of 2 in Tol-d8. 


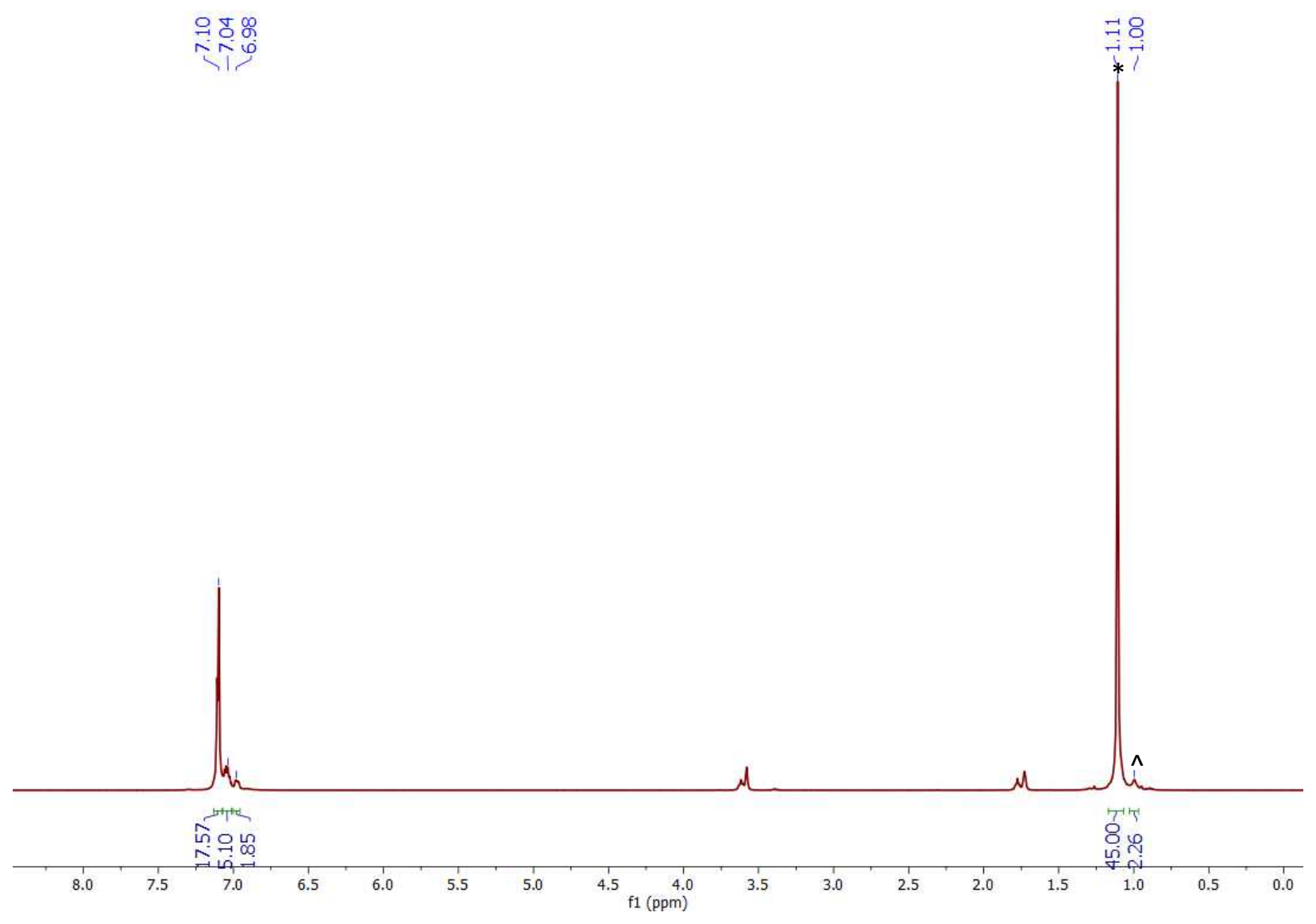

Figure S13. ${ }^{1} \mathrm{H}$ NMR spectrum of 2 in THF- $d_{8}$. Resonance marked with * is assignable to $[\mathrm{Li}]\left[\mathrm{Th}\left(\mathrm{N}=\mathrm{C}^{t} \mathrm{BuPh}\right)_{5}\right]\left(\mathbf{2}^{\prime}\right)$ and resonance marked with ${ }^{\wedge}$ is assignable to $\mathrm{Li}\left(\mathrm{N}=\mathrm{C}^{t} \mathrm{BuPh}\right)$. 


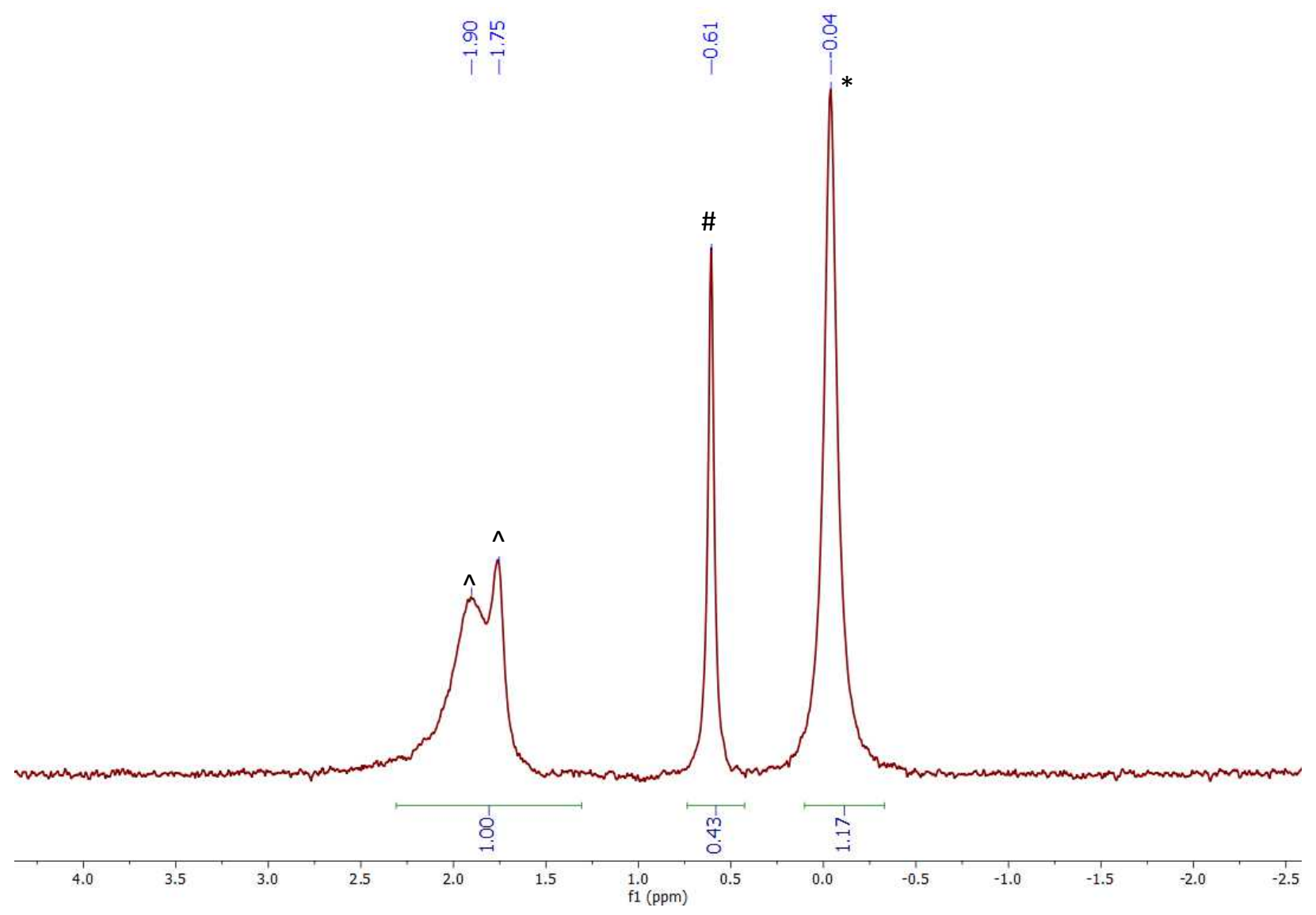

Figure S14. ${ }^{7} \mathrm{Li}\left\{{ }^{1} \mathrm{H}\right\}$ NMR spectrum of 2 in THF- $d_{8}$. Resonance marked with * is assignable to [Li] $\left[\mathrm{Th}\left(\mathrm{N}=\mathrm{C}^{t} \mathrm{BuPh}\right)_{5}\right]\left(\mathbf{2}^{\prime}\right)$, resonance marked with \# is assignable to $\mathbf{2}$, and resonances marked with $^{\wedge}$ are assignable to $\mathrm{Li}\left(\mathrm{N}=\mathrm{C}^{t} \mathrm{BuPh}\right)$. 


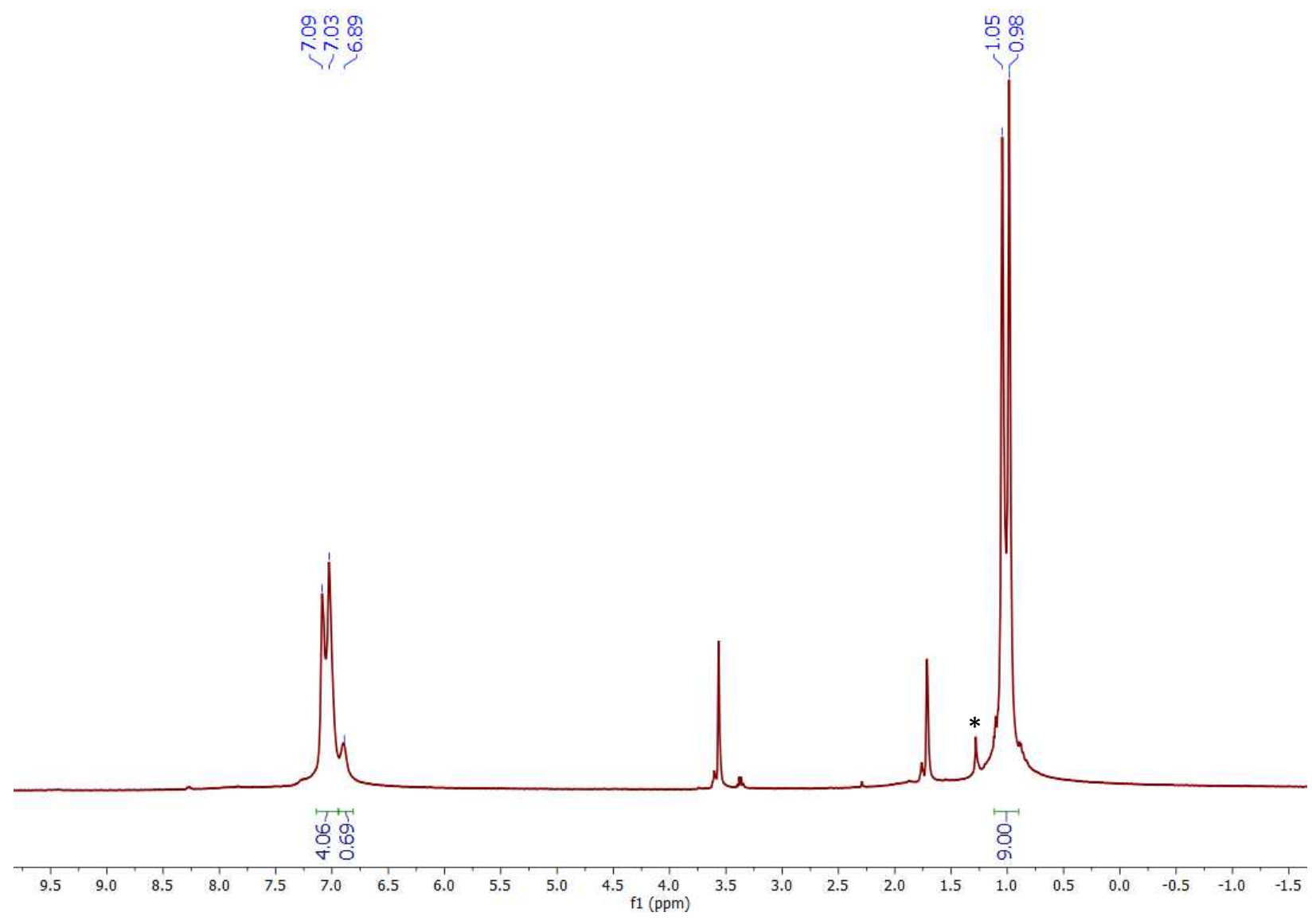

Figure S15. ${ }^{1} \mathrm{H}$ NMR spectrum of $\mathrm{Li}\left(\mathrm{N}=\mathrm{C} \mathrm{BuPh}^{t}\right)$ in THF- $d_{8}$. Resonance marked with * is assignable to hexanes. 


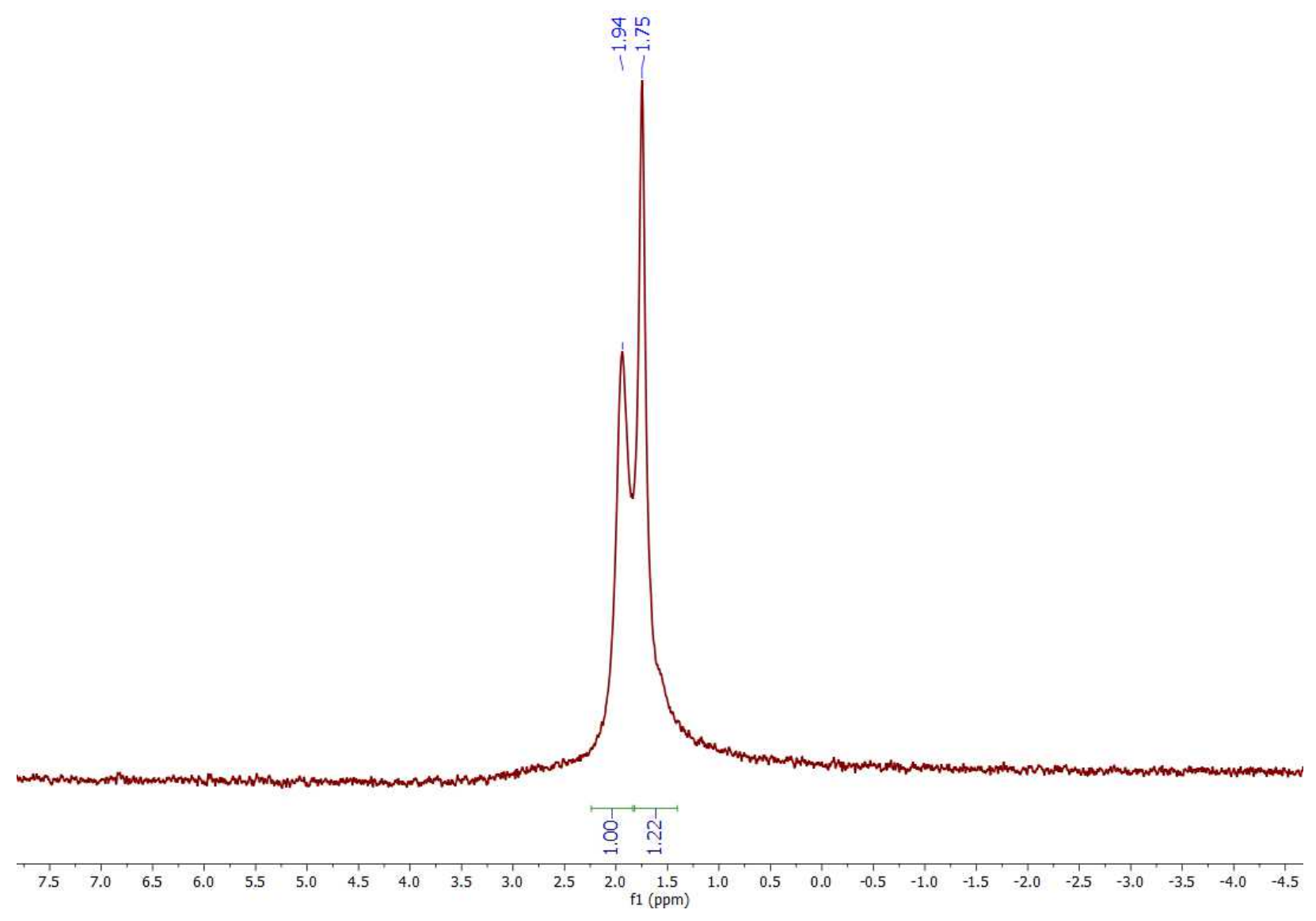

Figure S16. ${ }^{7} \mathrm{Li}\left\{{ }^{1} \mathrm{H}\right\}$ NMR spectrum of $\mathrm{Li}\left(\mathrm{N}=\mathrm{C}^{t} \mathrm{BuPh}\right)$ in THF-d8. 


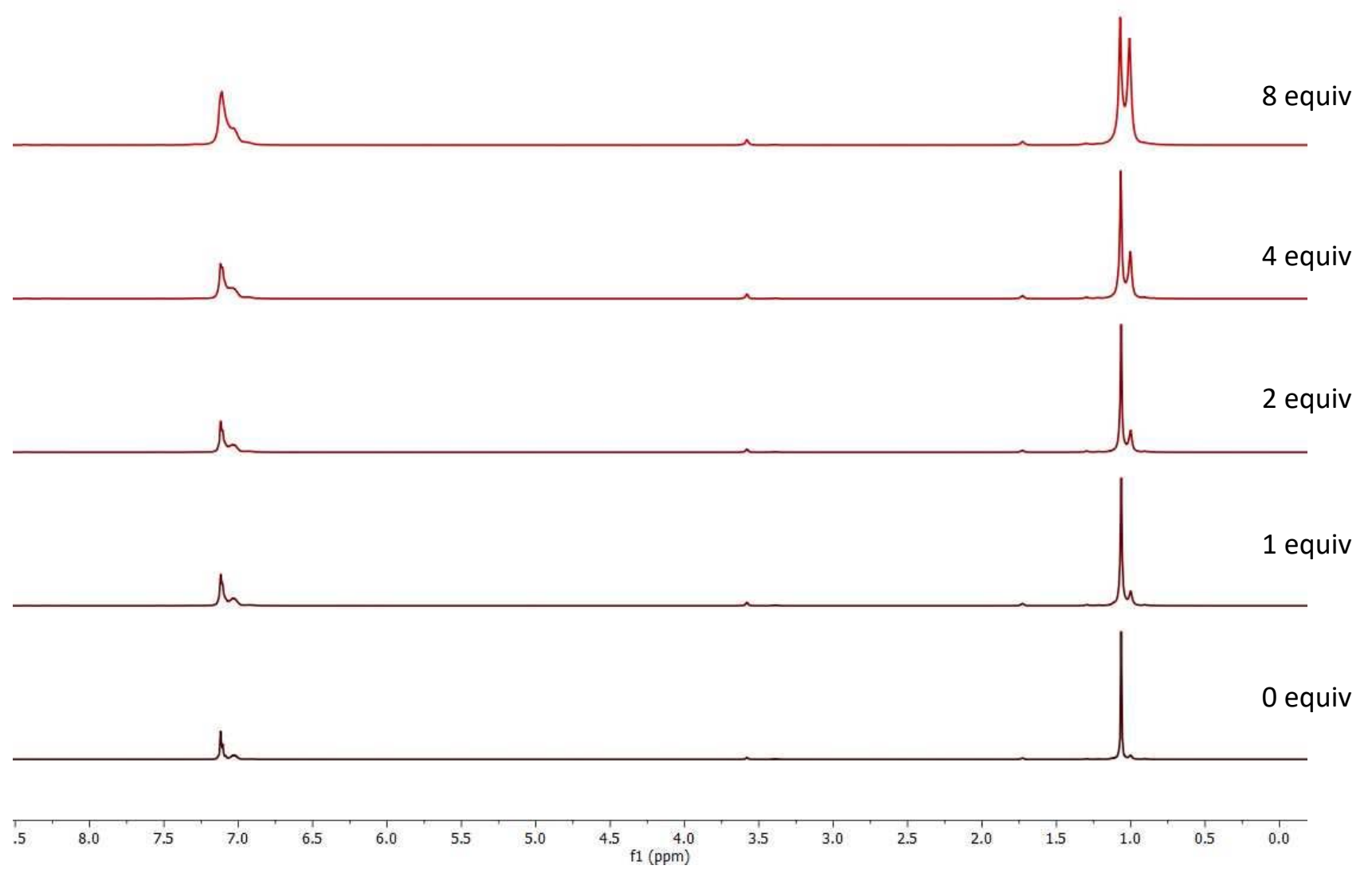

Figure S17. ${ }^{1} \mathrm{H}$ NMR spectra of the titration of 1 with $\mathrm{Li}\left(\mathrm{N}=\mathrm{C}^{t} \mathrm{BuPh}\right)$ in $\mathrm{THF}-d_{8}$. Experimental Details: Purple crystals of $1(19.5 \mathrm{mg}, 0.017 \mathrm{mmol})$ were dissolved in THF- $d_{8}(0.75 \mathrm{~mL})$ yielding a deep purple solution. The mixture was transferred to a J. Young NMR tube equipped with a rotoflow Teflon valve, brought out of the glovebox, and ${ }^{1} \mathrm{H}$ and ${ }^{7} \mathrm{Li}\left\{{ }^{1} \mathrm{H}\right\}$ spectra were recorded. The sample was then brought back into the glove box and $\mathrm{Li}\left(\mathrm{N}=\mathrm{C}^{t} \mathrm{BuPh}\right)$ was added as a solid (3.1 mg, $0.018 \mathrm{mmol}, 1$ equiv). No obvious color change was observed. The sample was brought out of the box and ${ }^{1} \mathrm{H}$ and ${ }^{7} \mathrm{Li}\left\{{ }^{1} \mathrm{H}\right\}$ spectra were re-recorded. This procedure was repeated three more times, bringing the total amount of $\mathrm{Li}\left(\mathrm{N}=\mathrm{C}^{t} \mathrm{BuPh}\right)$ added to 8 equiv. 


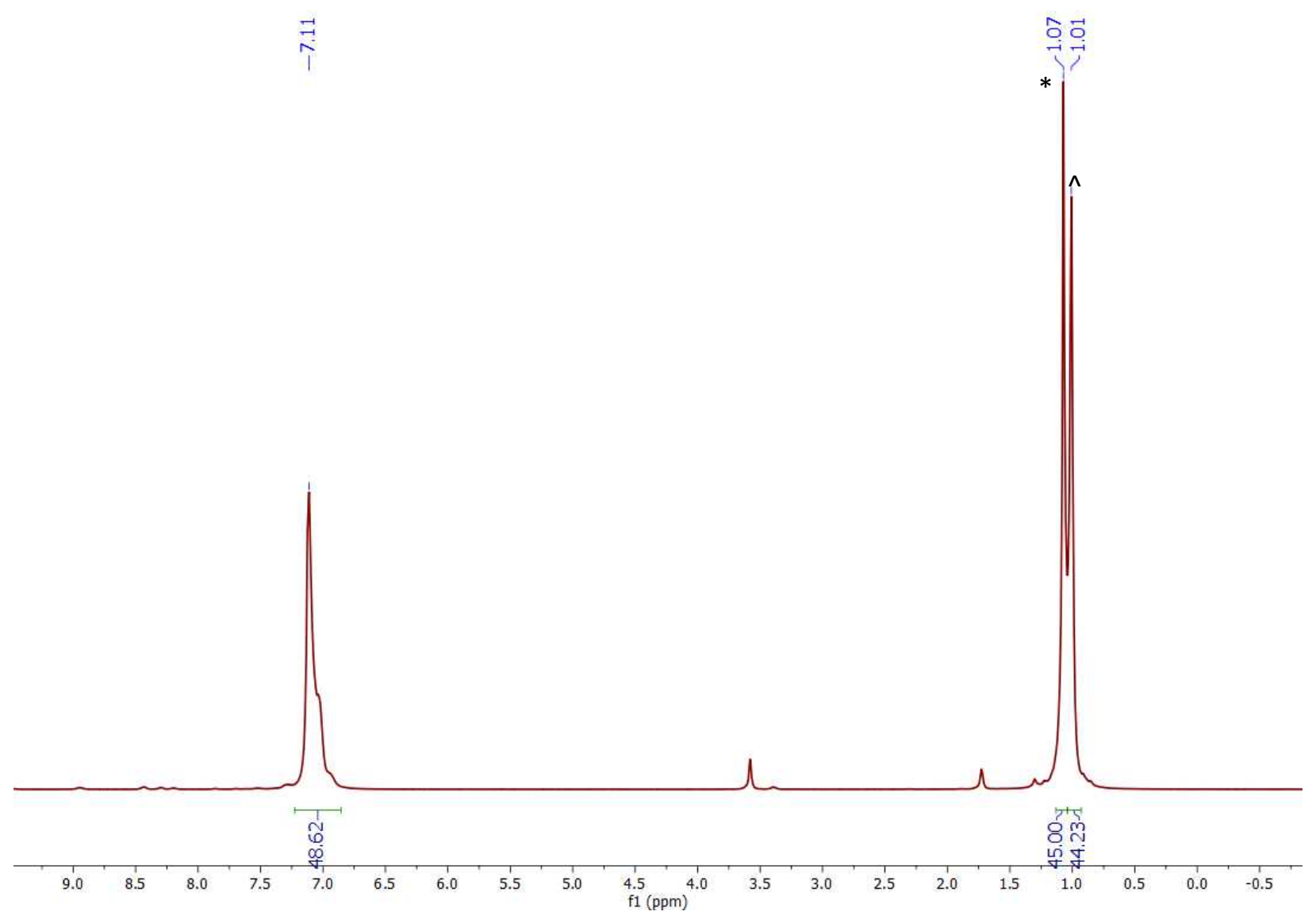

Figure S18. ${ }^{1} \mathrm{H}$ NMR spectrum of a mixture of 1 and 8 equiv of $\mathrm{Li}(\mathrm{N}=\mathrm{CtBuPh})$ in $\mathrm{THF}-\mathrm{d}_{8}$. The resonance marked with * is assignable to $[\mathrm{Li}]\left[\mathrm{Ce}\left(\mathrm{N}=\mathrm{C}^{t} \mathrm{BuPh}\right)_{5}\right]\left(\mathbf{1}^{\prime}\right)$ and the resonance marked with $^{\wedge}$ is assignable to $\mathrm{Li}\left(\mathrm{N}=\mathrm{C}^{t} \mathrm{BuPh}\right)$. 


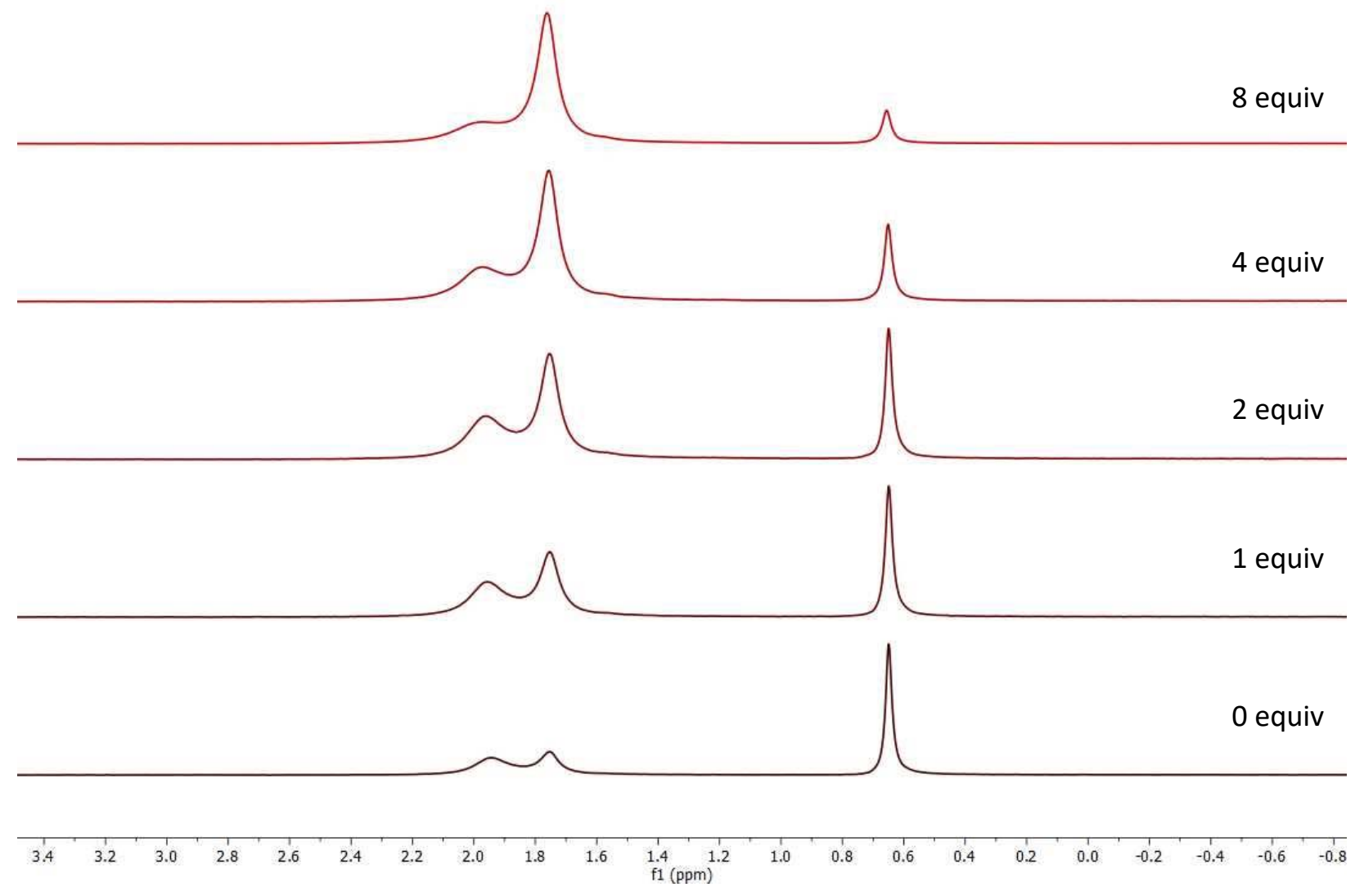

Figure S19. ${ }^{7} \mathrm{Li}\left\{{ }^{1} \mathrm{H}\right\}$ NMR spectra of the titration of 1 with $\mathrm{Li}\left(\mathrm{N}=\mathrm{C}{ }^{t} \mathrm{BuPh}\right)$ in THF-d8.

Experimental Details: See details for Figure S17. 


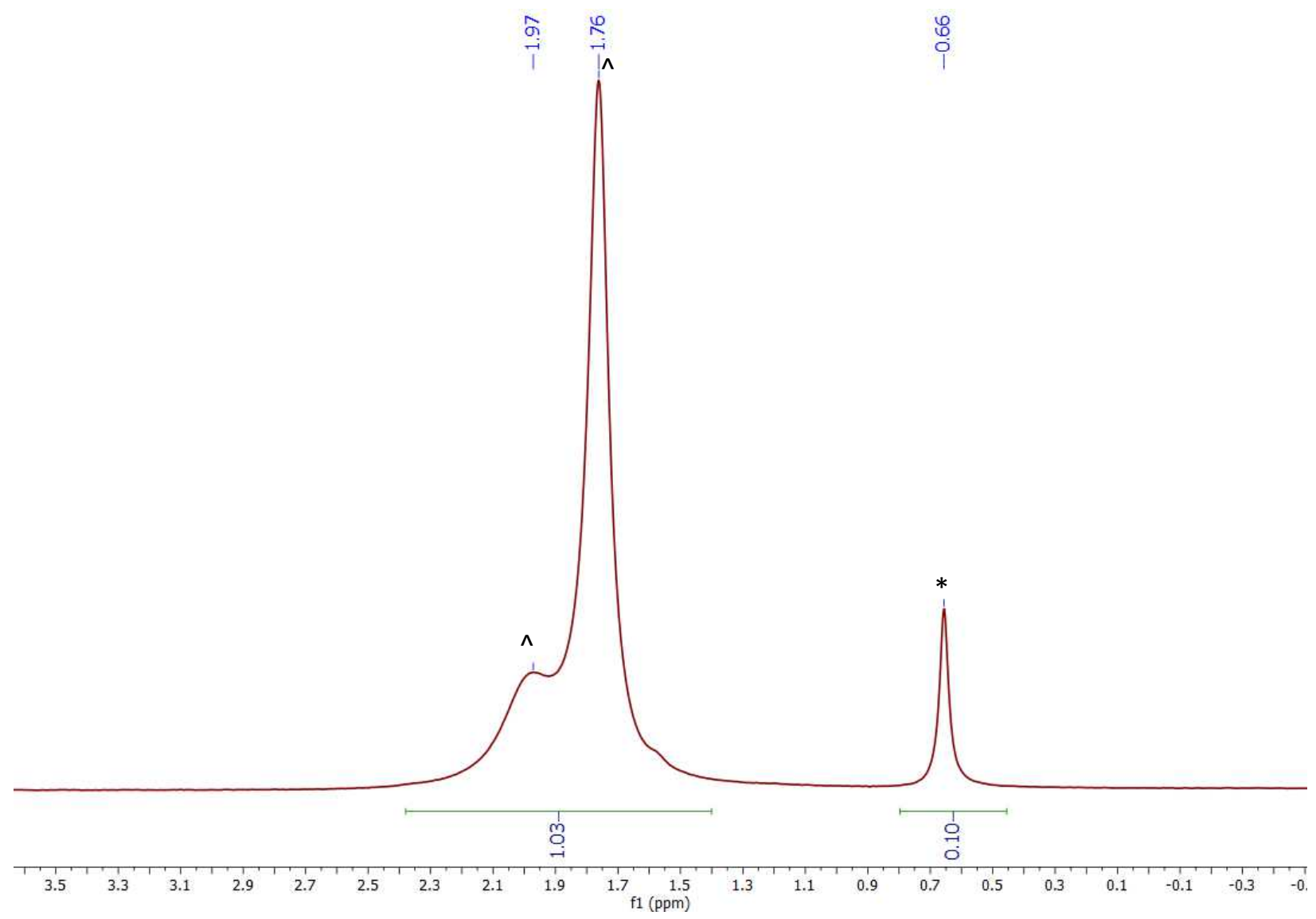

Figure S20. ${ }^{7} \mathrm{Li}\left\{{ }^{1} \mathrm{H}\right\}$ NMR spectrum of a mixture of 1 and 8 equiv of $\mathrm{Li}\left(\mathrm{N}=\mathrm{C}{ }^{t} \mathrm{BuPh}\right)$ in $\mathrm{THF}-d_{8}$. The resonance marked with * is assignable to $[\mathrm{Li}]\left[\mathrm{Ce}\left(\mathrm{N}=\mathrm{C}^{t} \mathrm{BuPh}\right)_{5}\right]\left(\mathbf{1}^{\prime}\right)$ and the resonances marked with ${ }^{\wedge}$ are assignable to $\mathrm{Li}\left(\mathrm{N}=\mathrm{C}^{t} \mathrm{BuPh}\right)$. 


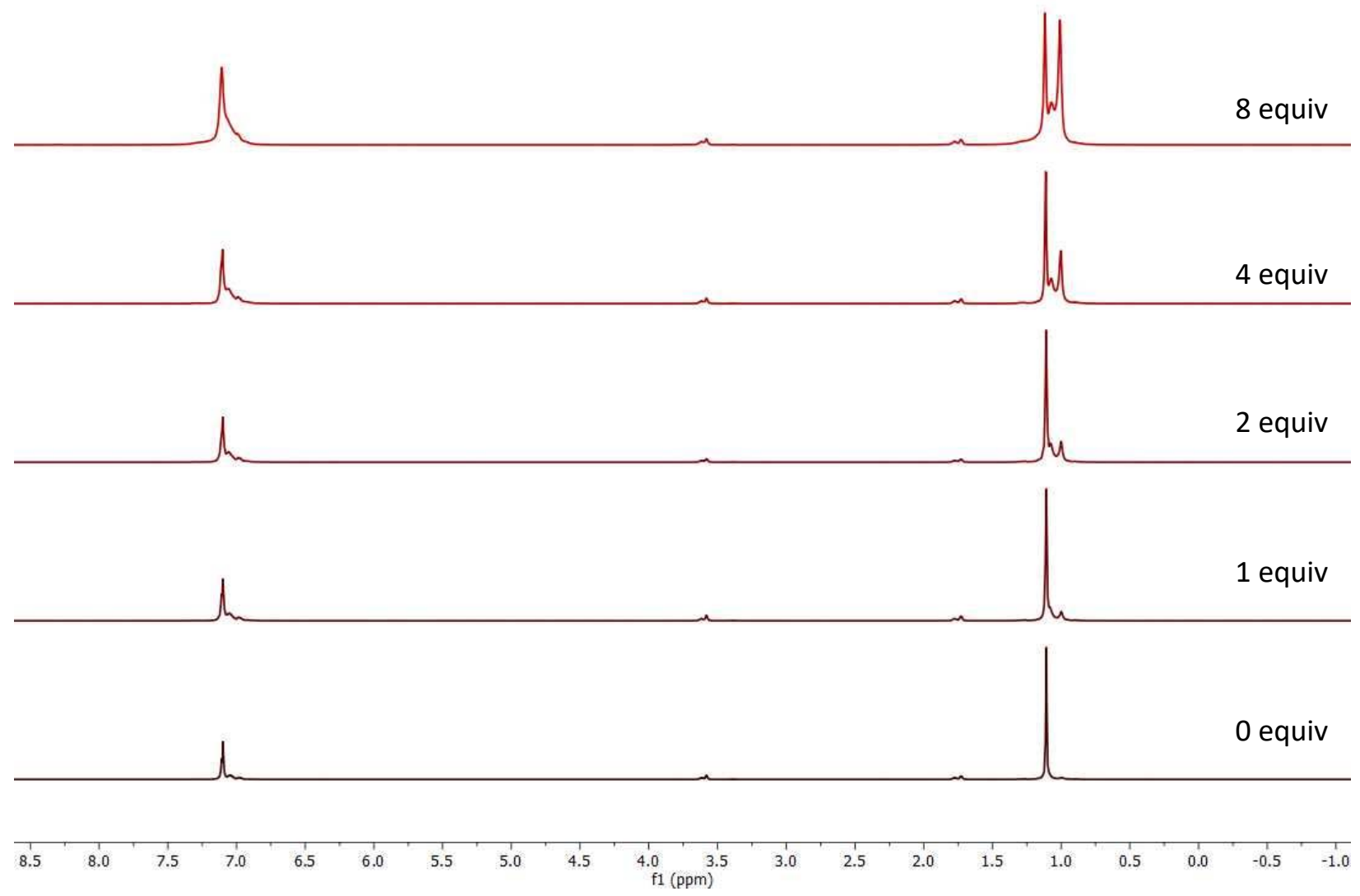

Figure S21. ${ }^{1} \mathrm{H}$ NMR spectra of the titration of 2 with $\mathrm{Li}\left(\mathrm{N}=\mathrm{C}^{t} \mathrm{BuPh}\right)$ in $\mathrm{THF}-d_{8}$. Experimental

Details: Yellow crystals of $2(21.2 \mathrm{mg}, 0.018 \mathrm{mmol})$ were dissolved in THF-d8 $(0.75 \mathrm{~mL})$

yielding a yellow solution. The mixture was transferred to a J. Young NMR tube equipped with a rotoflow Teflon valve, brought out of the glovebox, and ${ }^{1} \mathrm{H}$ and ${ }^{7} \mathrm{Li}\left\{{ }^{1} \mathrm{H}\right\}$ spectra were recorded. The sample was then brought back into the glove box and $\mathrm{Li}\left(\mathrm{N}=\mathrm{C}^{t} \mathrm{BuPh}\right)$ was added as a solid (2.9 mg, $0.017 \mathrm{mmol}, 1$ equiv). No obvious color change was observed. The sample was brought out of the box and ${ }^{1} \mathrm{H}$ and ${ }^{7} \mathrm{Li}\left\{{ }^{1} \mathrm{H}\right\}$ spectra were re-recorded. This procedure was repeated three more times, bringing the total amount of $\mathrm{Li}\left(\mathrm{N}=\mathrm{C}^{t} \mathrm{BuPh}\right)$ added to 8 equiv. 


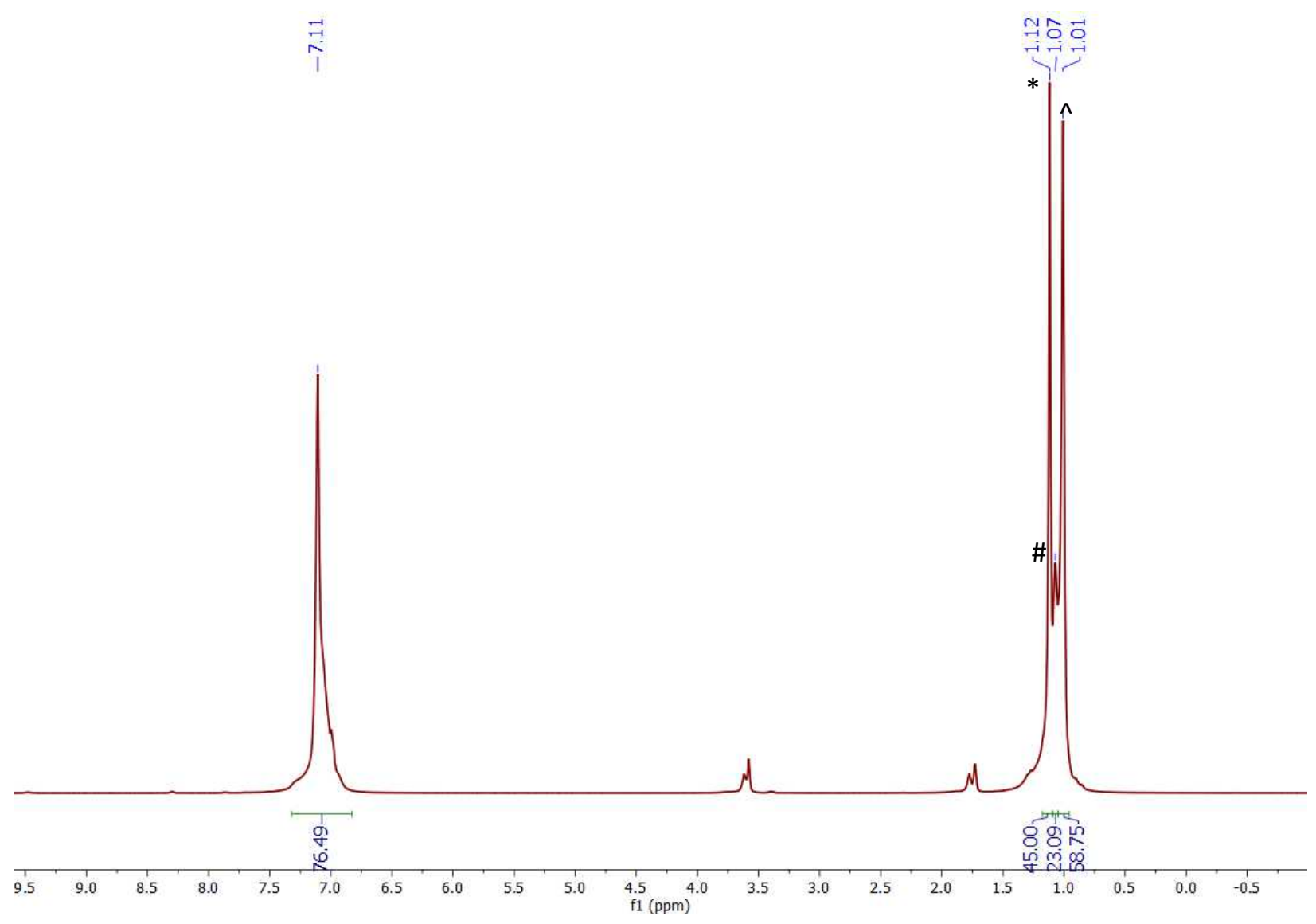

Figure S22. ${ }^{1} \mathrm{H}$ NMR spectrum of a mixture of 2 and 8 equiv of $\mathrm{Li}\left(\mathrm{N}=\mathrm{C}{ }^{t} \mathrm{BuPh}\right)$ in $\mathrm{THF}-\mathrm{d}_{8}$. The resonance marked with * is assignable to [ $\mathrm{Li}]\left[\mathrm{Th}\left(\mathrm{N}=\mathrm{C}^{t} \mathrm{BuPh}\right)_{5}\right]\left(\mathbf{2}^{\prime}\right)$, the resonance marked with \# is assignable to 2 , and the resonance marked with ${ }^{\wedge}$ is assignable to $\mathrm{Li}\left(\mathrm{N}=\mathrm{C}^{t} \mathrm{BuPh}\right)$. 


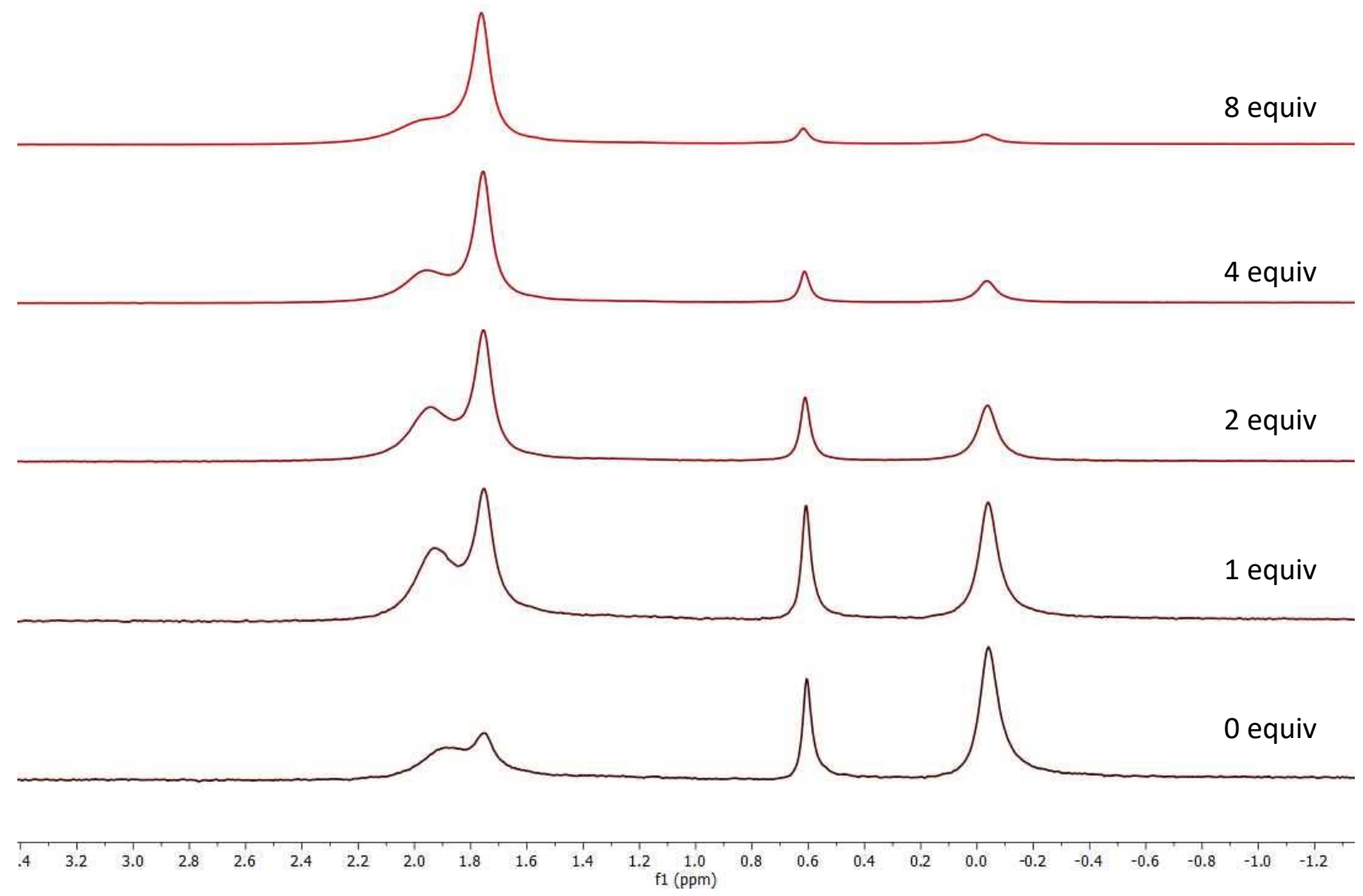

Figure S23. ${ }^{7} \mathrm{Li}\left\{{ }^{1} \mathrm{H}\right\}$ NMR spectra of the titration of 2 with $\mathrm{Li}\left(\mathrm{N}=\mathrm{C}{ }^{t} \mathrm{BuPh}\right)$ in THF- $d_{8}$.

Experimental Details: See details for Figure S21. 


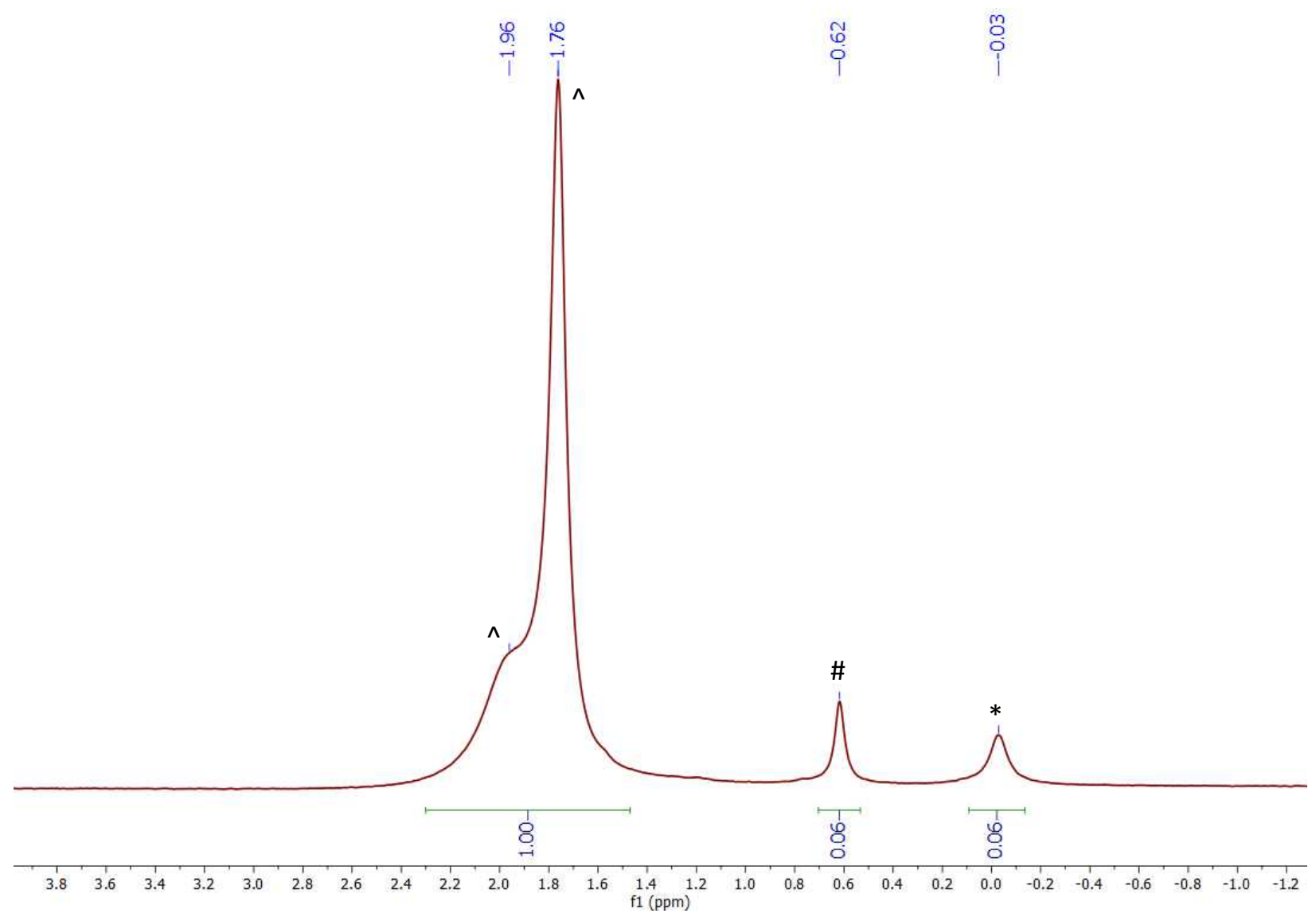

Figure S24. ${ }^{7} \mathrm{Li}\left\{{ }^{1} \mathrm{H}\right\}$ NMR spectrum of a mixture of 2 and 8 equiv of $\mathrm{Li}\left(\mathrm{N}=\mathrm{C}^{t} \mathrm{BuPh}\right)$ in $\mathrm{THF}-d_{8}$. The resonance marked with * is assignable to [ $\mathrm{Li}]\left[\mathrm{Th}\left(\mathrm{N}=\mathrm{C}^{t} \mathrm{BuPh}\right)_{5}\right]\left(\mathbf{2}^{\prime}\right)$, the resonance marked with \# is assignable to $\mathbf{2}$, and the resonances marked with ${ }^{\wedge}$ are assignable to $\mathrm{Li}\left(\mathrm{N}=\mathrm{C}^{t} \mathrm{BuPh}\right)$. 
Table S1. Crystallographic details for complexes $\mathbf{1}$ and $\mathbf{2 .}$

\begin{tabular}{|c|c|c|}
\hline & 1 & 2 \\
\hline Formula & $\mathrm{C}_{66} \mathrm{H}_{84} \mathrm{CeLi}_{2} \mathrm{~N}_{6}$ & $\mathrm{C}_{66} \mathrm{H}_{84} \mathrm{Li}_{2} \mathrm{~N}_{6} \mathrm{Th}$ \\
\hline Crystal Habit, Color & Plate, Purple & Diamond, Yellow \\
\hline Crystal Size (mm) & $0.20 \times 0.15 \times 0.10$ & $0.15 \times 0.10 \times 0.05$ \\
\hline MW (g/mol) & 1115.39 & 1207.31 \\
\hline crystal system & Trigonal & Trigonal \\
\hline space group & $\mathrm{R}-3$ & $\mathrm{R}-3$ \\
\hline $\mathrm{a}(\AA)$ & $12.350(3)$ & $12.1710(17)$ \\
\hline $\mathrm{b}(\AA)$ & $12.350(3)$ & $12.1710(17)$ \\
\hline c $(\AA)$ & $36.693(10)$ & $37.279(5)$ \\
\hline$\alpha\left(^{\circ}\right)$ & 90 & 90 \\
\hline$\beta\left(^{\circ}\right)$ & 90 & 90 \\
\hline$\gamma\left({ }^{\circ}\right)$ & 120 & 120 \\
\hline $\mathrm{V}\left(\AA^{3}\right)$ & $4847(3)$ & $4782.5(15)$ \\
\hline $\mathrm{Z}$ & 3 & 3 \\
\hline $\mathrm{T}(\mathrm{K})$ & $100(2)$ & $100(2)$ \\
\hline$\lambda(\AA)$ & 0.71073 & 0.71073 \\
\hline GOF & 1.293 & 1.044 \\
\hline $\begin{array}{l}\text { Density (calcd) } \\
\left(\mathrm{Mg} / \mathrm{m}^{3}\right)\end{array}$ & 1.146 & 1.258 \\
\hline $\begin{array}{l}\text { Absorption coefficient } \\
\left(\mathrm{mm}^{-1}\right)\end{array}$ & 0.745 & 2.380 \\
\hline $\mathrm{F}_{000}$ & 1758 & 1854 \\
\hline Total no Reflections & 3987 & 8244 \\
\hline Unique Reflections & 2439 & 2656 \\
\hline Final $\mathrm{R}$ indices* & $\begin{array}{l}\mathrm{R}_{1}=0.0846 \\
\mathrm{wR}_{2}=0.2501\end{array}$ & $\begin{array}{l}\mathrm{R}_{1}=0.0194 \\
\mathrm{wR}_{2}=0.0423\end{array}$ \\
\hline $\begin{array}{l}\text { Largest Diff. peak and } \\
\text { hole }\left(\mathrm{e}^{-} \mathrm{A}^{-3}\right)\end{array}$ & $1.229,-0.647$ & $0.526,-0.320$ \\
\hline
\end{tabular}




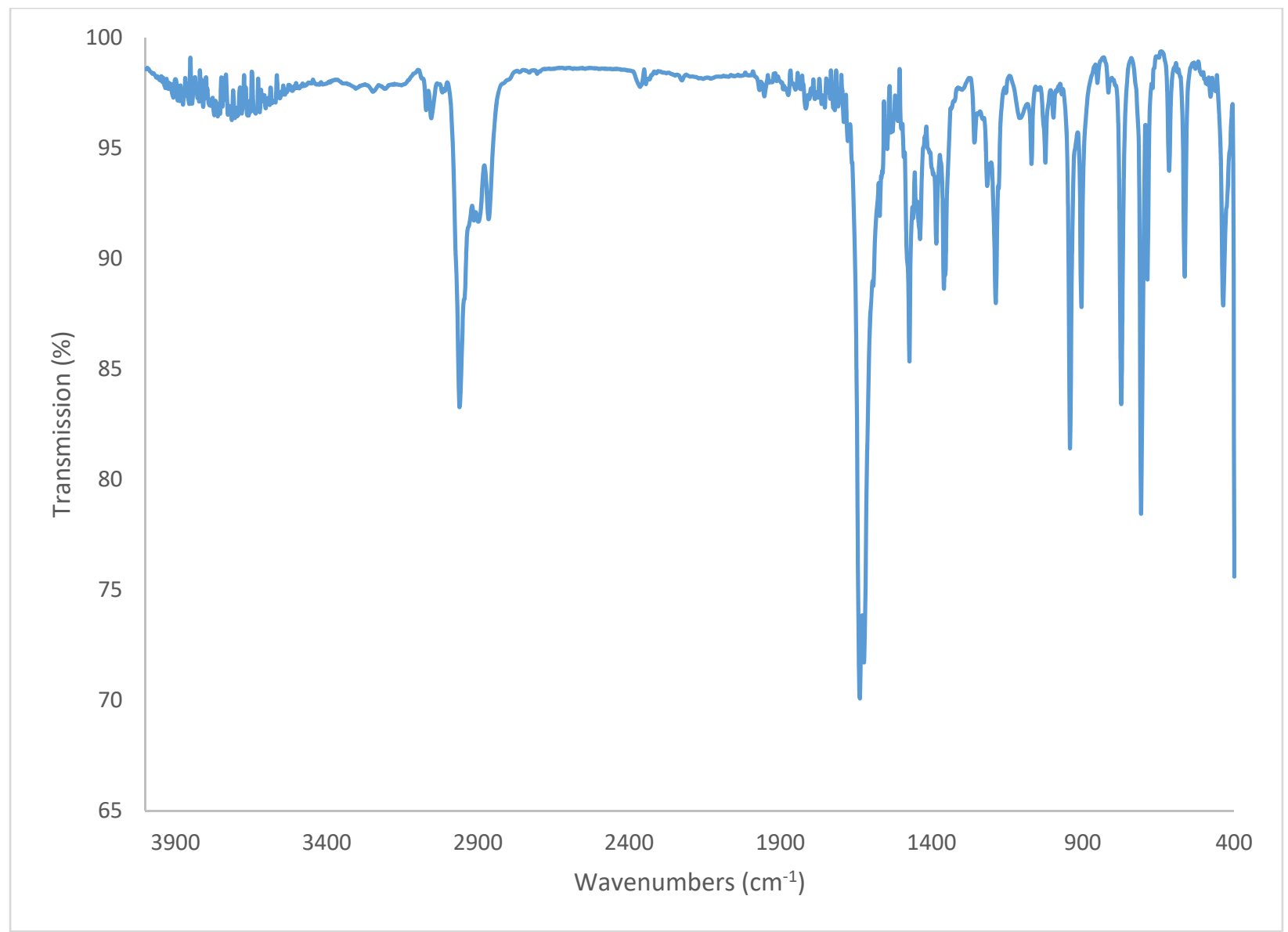

Figure S25. IR spectrum of $\mathbf{1}$ ( $\mathrm{KBr}$ pellet). 


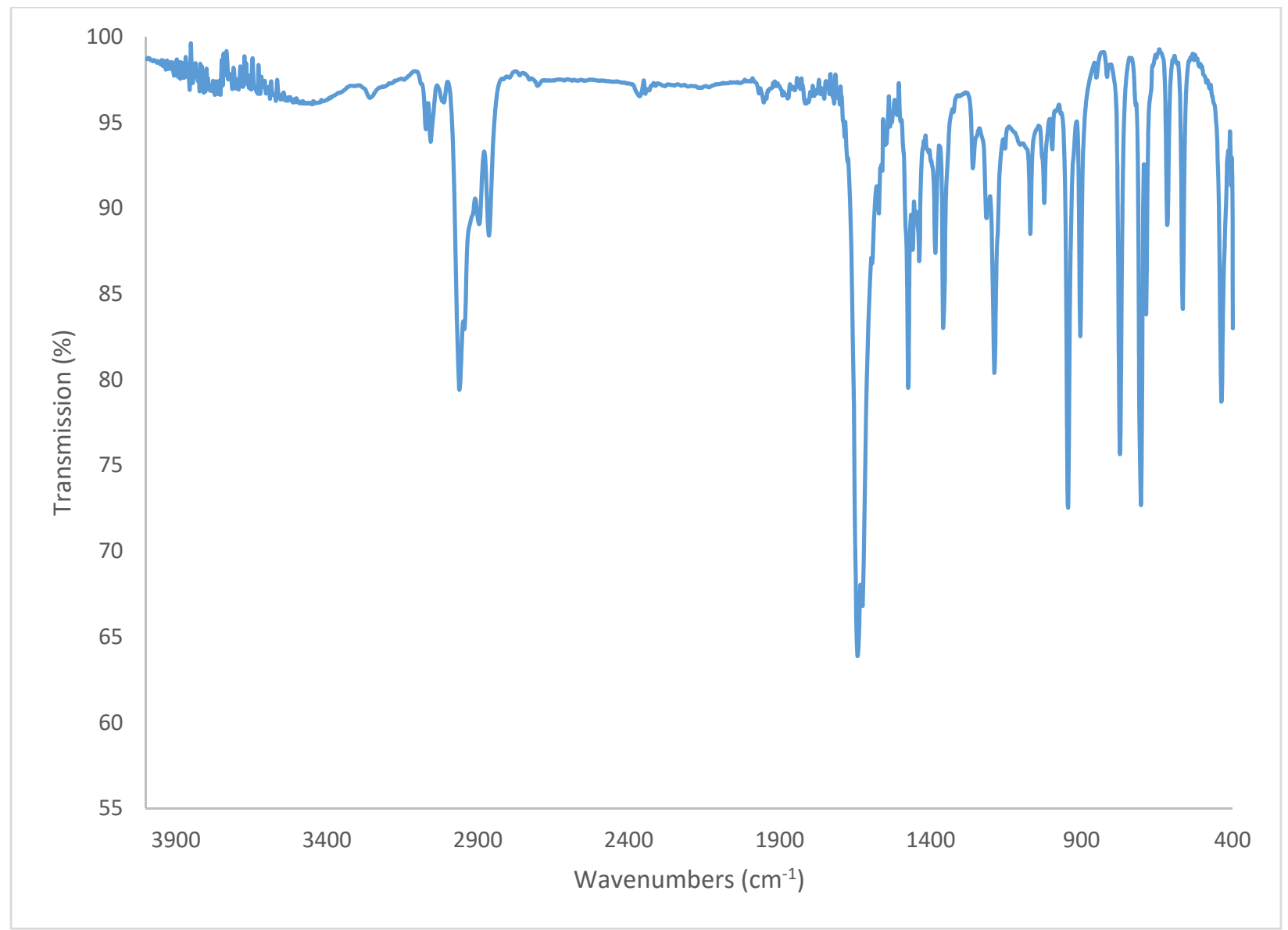

Figure S26. IR spectrum of $\mathbf{2}$ (KBr pellet). 


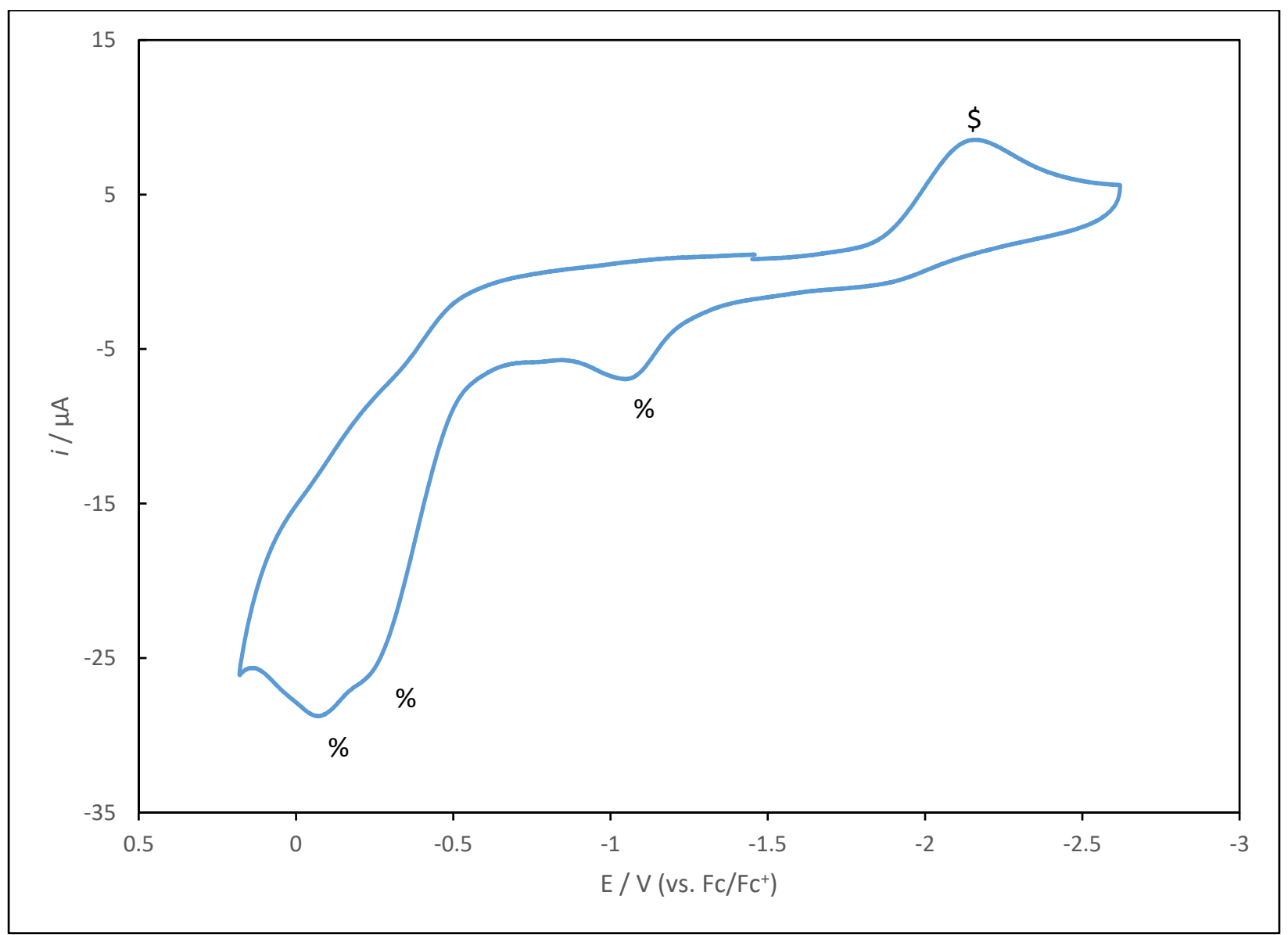

Figure S27. Cyclic voltammogram of complex $1\left(200 \mathrm{mV} / \mathrm{s}\right.$ scan rate, vs. $\left.\mathrm{Fc} / \mathrm{Fc}^{+}\right)$. Measured in THF with $0.1 \mathrm{M}\left[\mathrm{NBu}_{4}\right]\left[\mathrm{BPh}_{4}\right]$ as the supporting electrolyte. $\$$ is assignable to the irreversible $\mathrm{Ce}(\mathrm{IV} / \mathrm{III})$ reduction, and \% are assignable to irreversible ketimide ligand oxidation events. 


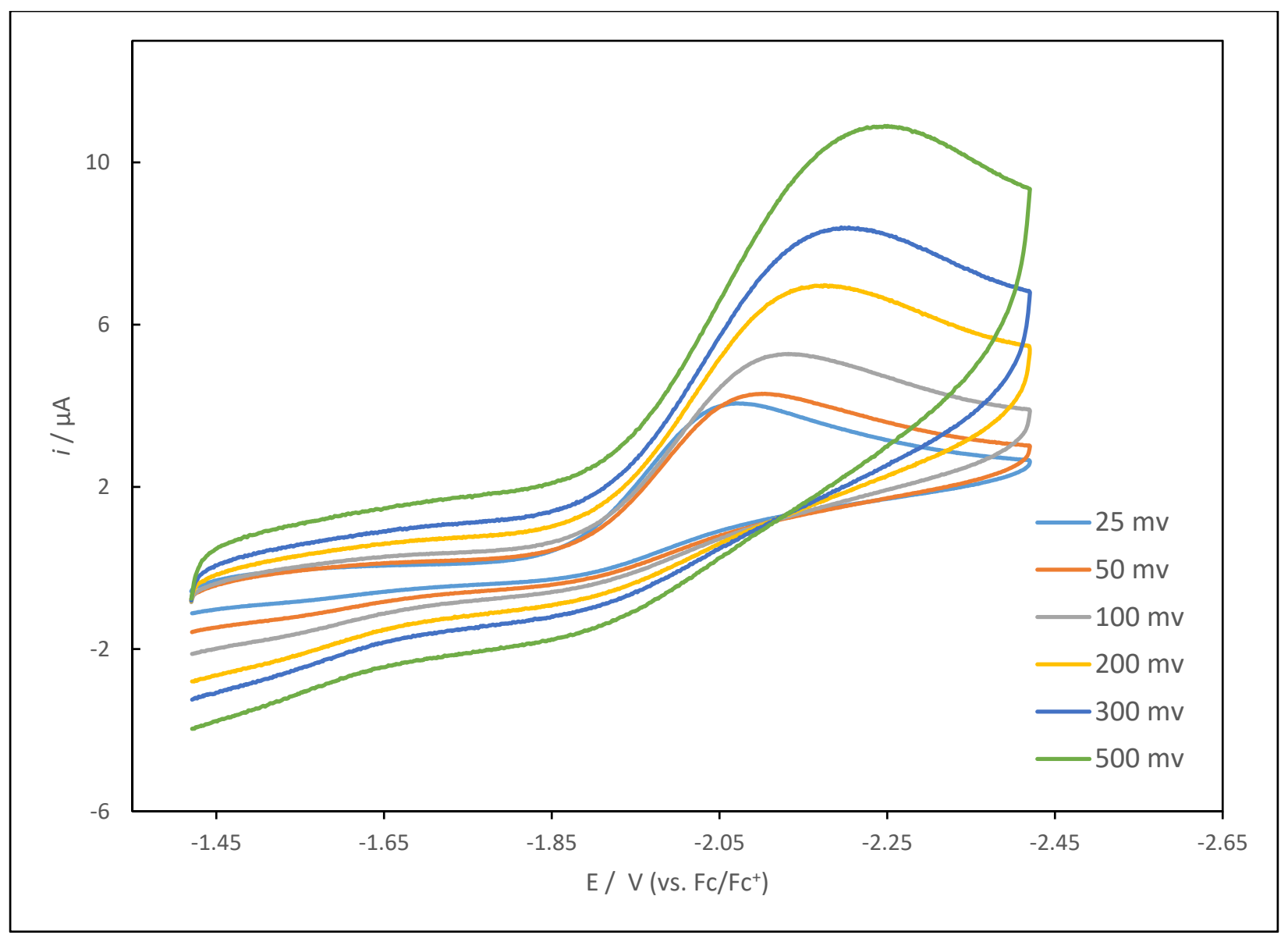

Figure S28. Cyclic voltammogram of the irreversible $\mathrm{Ce}(\mathrm{IV}) / \mathrm{Ce}(\mathrm{III})$ reduction event of complex 1 measured in THF with $0.1 \mathrm{M}\left[\mathrm{NBu}_{4}\right]\left[\mathrm{BPh}_{4}\right]$ as the supporting electrolyte ( $\mathrm{vs}$. $\mathrm{Fc} / \mathrm{Fc}^{+}$). 


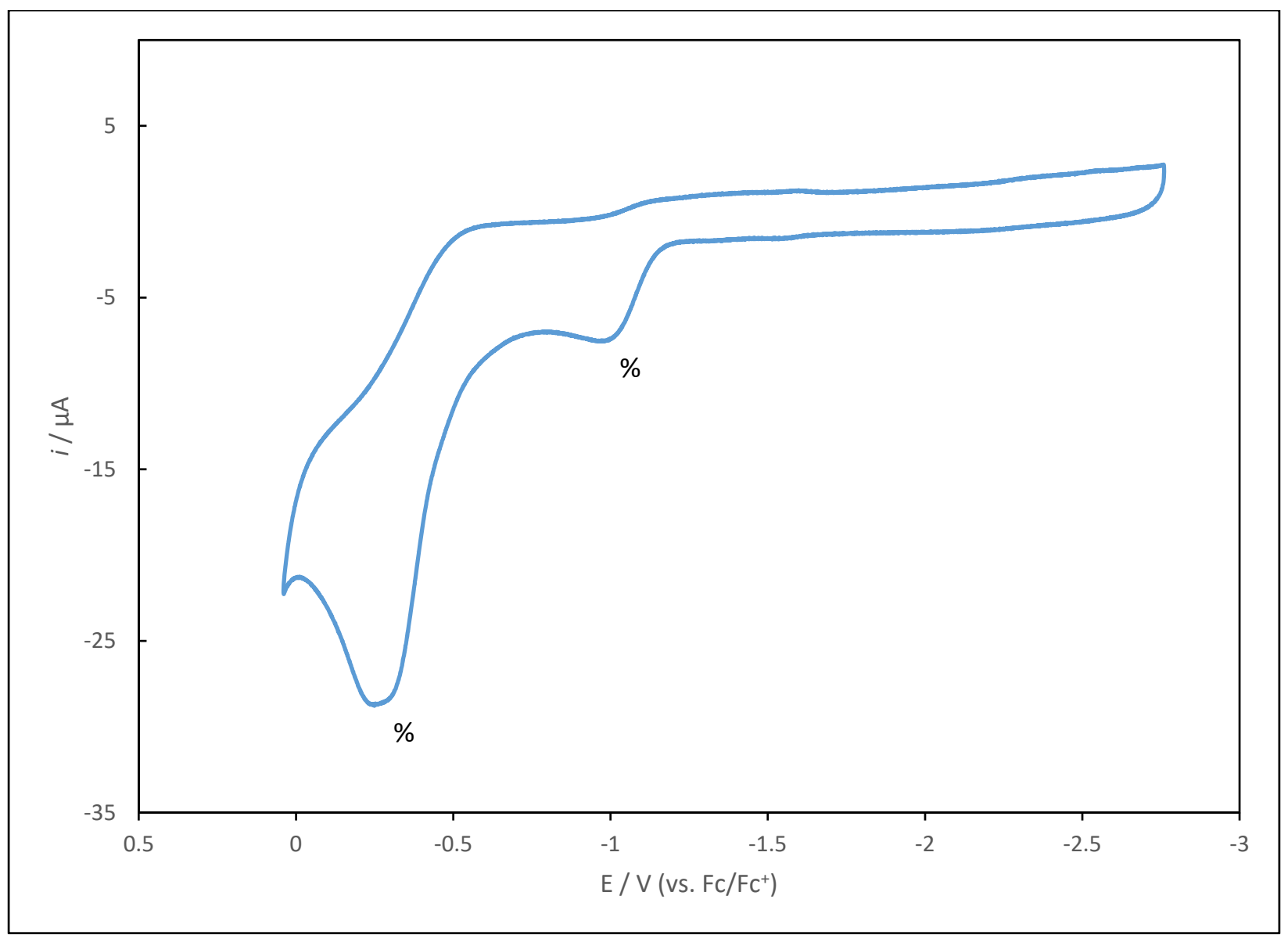

Figure S29. Cyclic voltammogram of complex $2\left(200 \mathrm{mV} / \mathrm{s}\right.$ scan rate, vs. $\left.\mathrm{Fc} / \mathrm{Fc}^{+}\right)$. Measured in THF with $0.1 \mathrm{M}\left[\mathrm{NBu}_{4}\right]\left[\mathrm{BPh}_{4}\right]$ as the supporting electrolyte. \% are assignable to irreversible ketimide ligand oxidation events. 


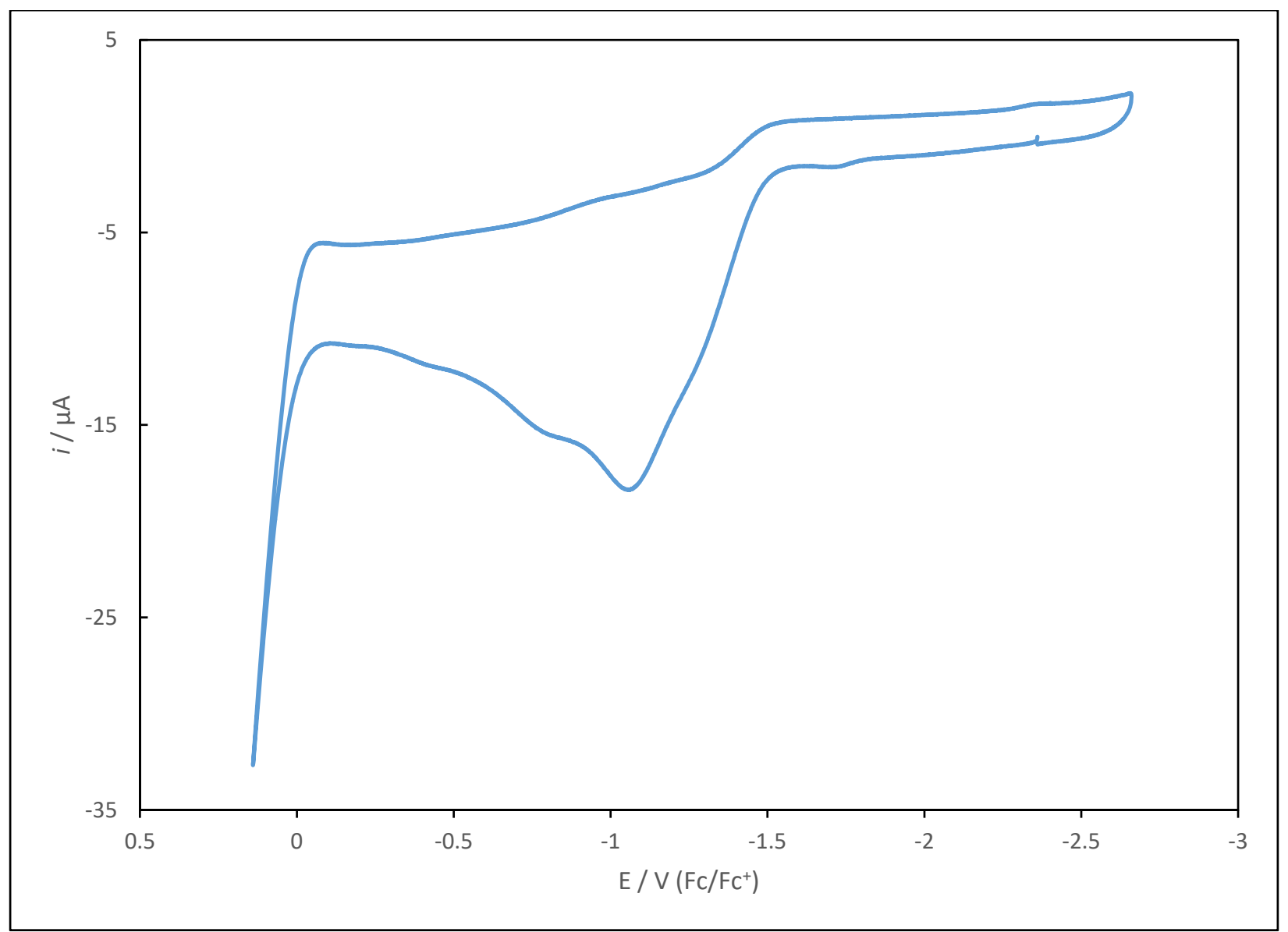

Figure S30. Cyclic voltammogram of $\mathrm{Li}\left(\mathrm{N}=\mathrm{C}^{t} \mathrm{BuPh}\right)\left(200 \mathrm{mV} / \mathrm{s}\right.$ scan rate, $\left.\mathrm{vs} . \mathrm{Fc} / \mathrm{Fc}^{+}\right)$. Measured in THF with $0.1 \mathrm{M}\left[\mathrm{NBu}_{4}\right]\left[\mathrm{BPh}_{4}\right]$ as the supporting electrolyte. 
Table S2. Electrochemical parameters for $[\mathrm{Li}]_{2}\left[\mathrm{Ce}\left(\mathrm{N}=\mathrm{C}^{t} \mathrm{BuPh}\right)_{6}\right]$ (1) in THF (vs. $\mathrm{Fc} / \mathrm{Fc}^{+}$, $[\mathrm{NBu} 4]\left[\mathrm{BPh}_{4}\right]$ as the supporting electrolyte)

\begin{tabular}{lcc}
\hline $\begin{array}{l}\text { Reduction } \\
\text { Feature }\end{array}$ & Scan Rate, V/s & $\mathbf{E}_{\mathbf{p}, \mathbf{c}}, \mathbf{V}$ \\
\hline & 0.025 & -2.034 \\
& 0.050 & -2.096 \\
& 0.100 & -2.122 \\
& 0.200 & -2.158 \\
& 0.300 & -2.189 \\
& 0.500 & -2.228 \\
\hline
\end{tabular}

\begin{tabular}{ccc}
\hline $\begin{array}{c}\text { Oxidation } \\
\text { Feature }\end{array}$ & Scan Rate, $\mathbf{V} / \mathbf{s}$ & $\mathbf{E}_{\mathbf{p}, \mathbf{a}}, \mathbf{V}$ \\
\hline 1 & 0.200 & -0.082 \\
2 & 0.200 & -0.231 \\
3 & 0.200 & -1.067 \\
\hline
\end{tabular}

Table S3. Electrochemical parameters for $[\mathrm{Li}]_{2}\left[\mathrm{Th}\left(\mathrm{N}=\mathrm{C}^{t} \mathrm{BuPh}\right)_{6}\right]$ (2) in THF (vs. $\mathrm{Fc} / \mathrm{Fc}^{+}$, $[\mathrm{NBu} 4][\mathrm{BPh} 4]$ as the supporting electrolyte)

\begin{tabular}{ccc}
\hline $\begin{array}{l}\text { Oxidation } \\
\text { Feature }\end{array}$ & Scan Rate, $\mathbf{V} / \mathbf{s}$ & $\mathbf{E}_{\mathbf{p}, \mathbf{a}}, \mathbf{V}$ \\
\hline 1 & 0.200 & -0.261 \\
2 & 0.200 & -0.997 \\
\hline
\end{tabular}

Table S4. Electrochemical parameters for $\mathrm{Li}\left(\mathrm{N}=\mathrm{C}{ }^{t} \mathrm{BuPh}\right)$ in $\mathrm{THF}$ (vs. $\mathrm{Fc} / \mathrm{Fc}^{+}$, $[\mathrm{NBu} 4]\left[\mathrm{BPh}_{4}\right]$ as the supporting electrolyte)

\begin{tabular}{ccc}
\hline $\begin{array}{l}\text { Oxidation } \\
\text { Feature }\end{array}$ & Scan Rate, $\mathbf{V} / \mathbf{s}$ & $\mathbf{E}_{\mathbf{p}, \mathrm{a}}, \mathbf{V}$ \\
\hline 1 & 0.200 & -0.807 \\
2 & 0.200 & -1.063 \\
\hline
\end{tabular}




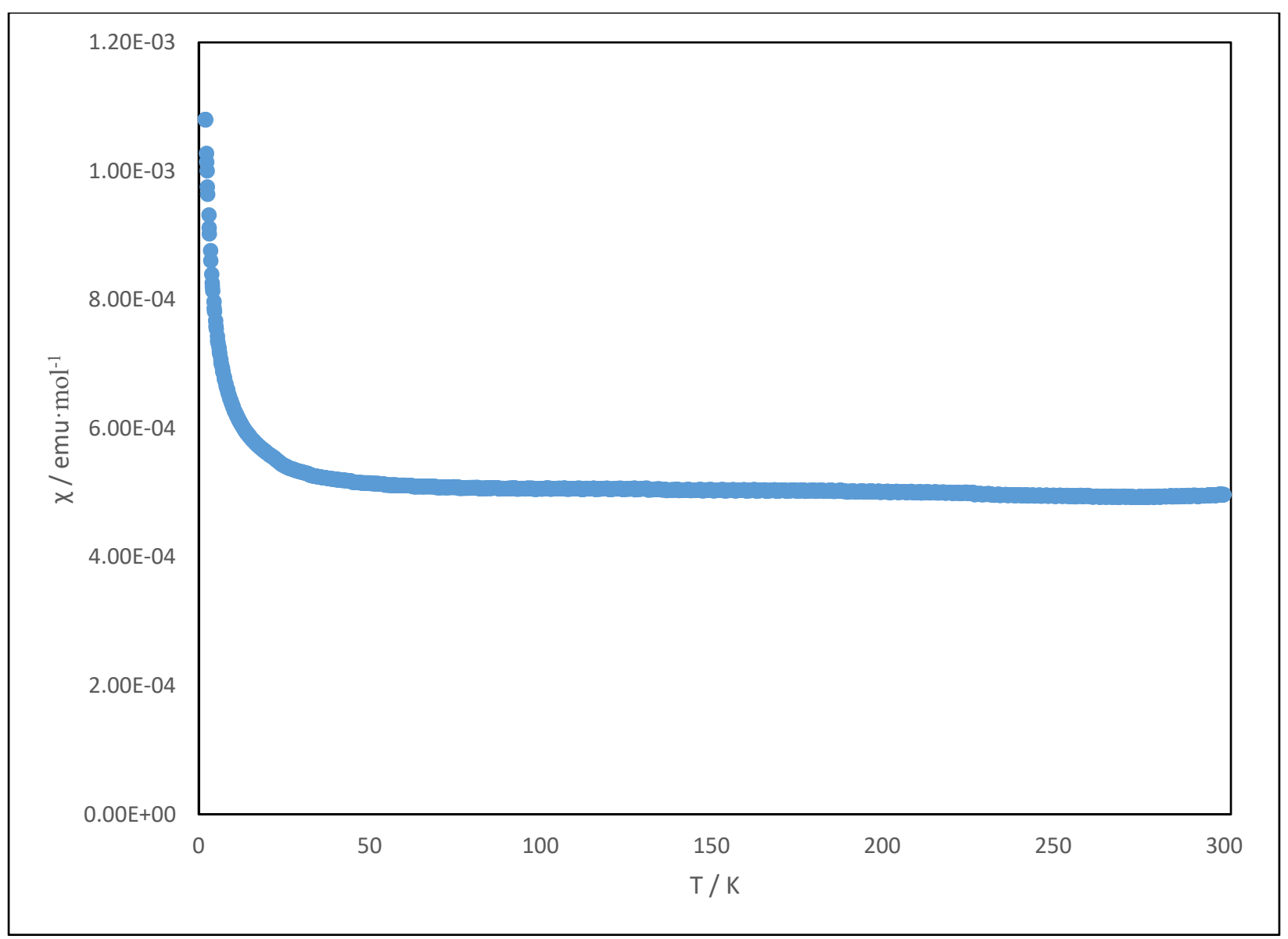

Figure S31. Variable-temperature magnetic susceptibility $(\chi)$ data for 1 collected at 1 Tesla. 


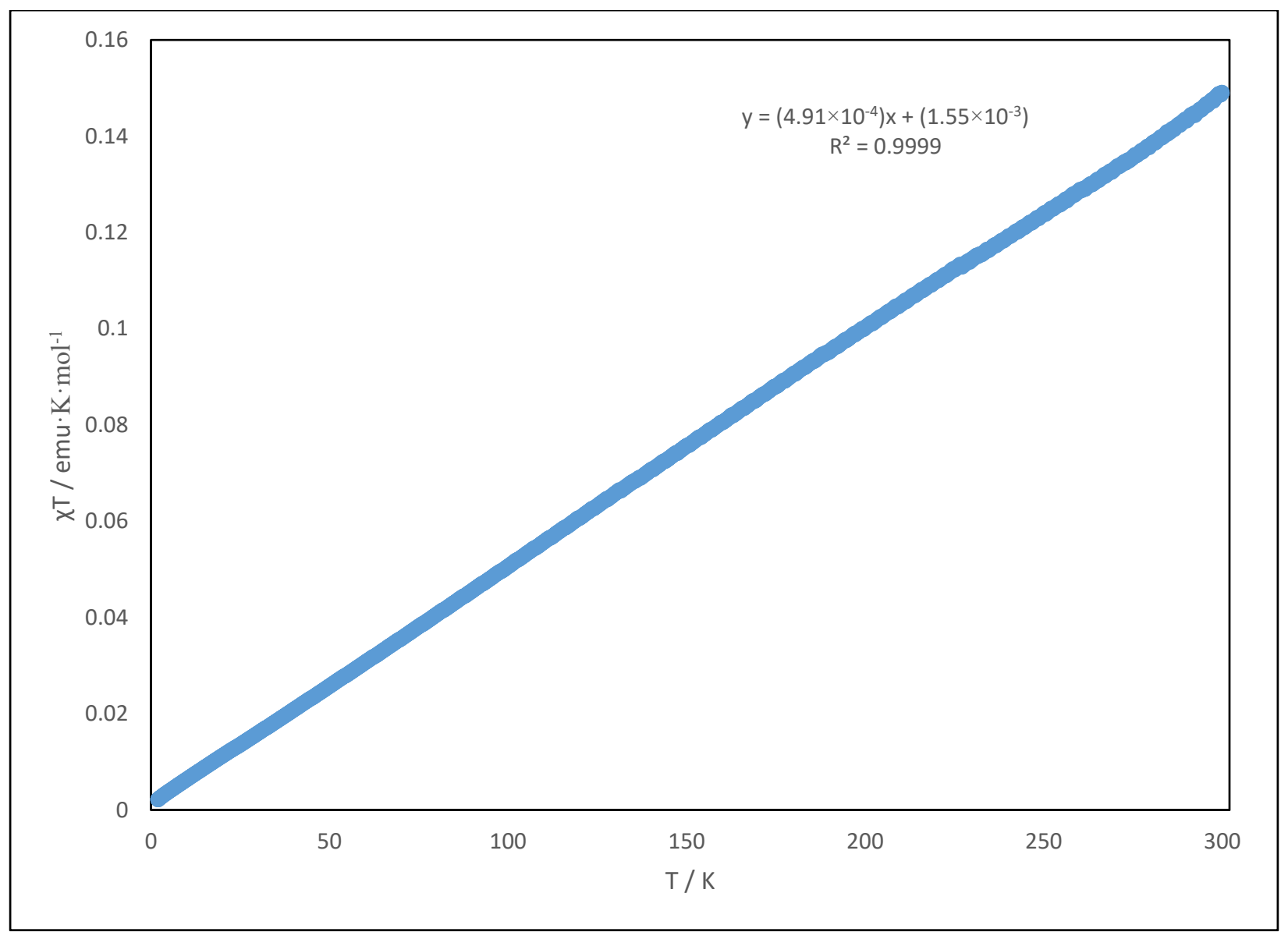

Figure S32. Variable-temperature magnetic susceptibility $(\chi \mathrm{T})$ data for 1 collected at 1 Tesla. 


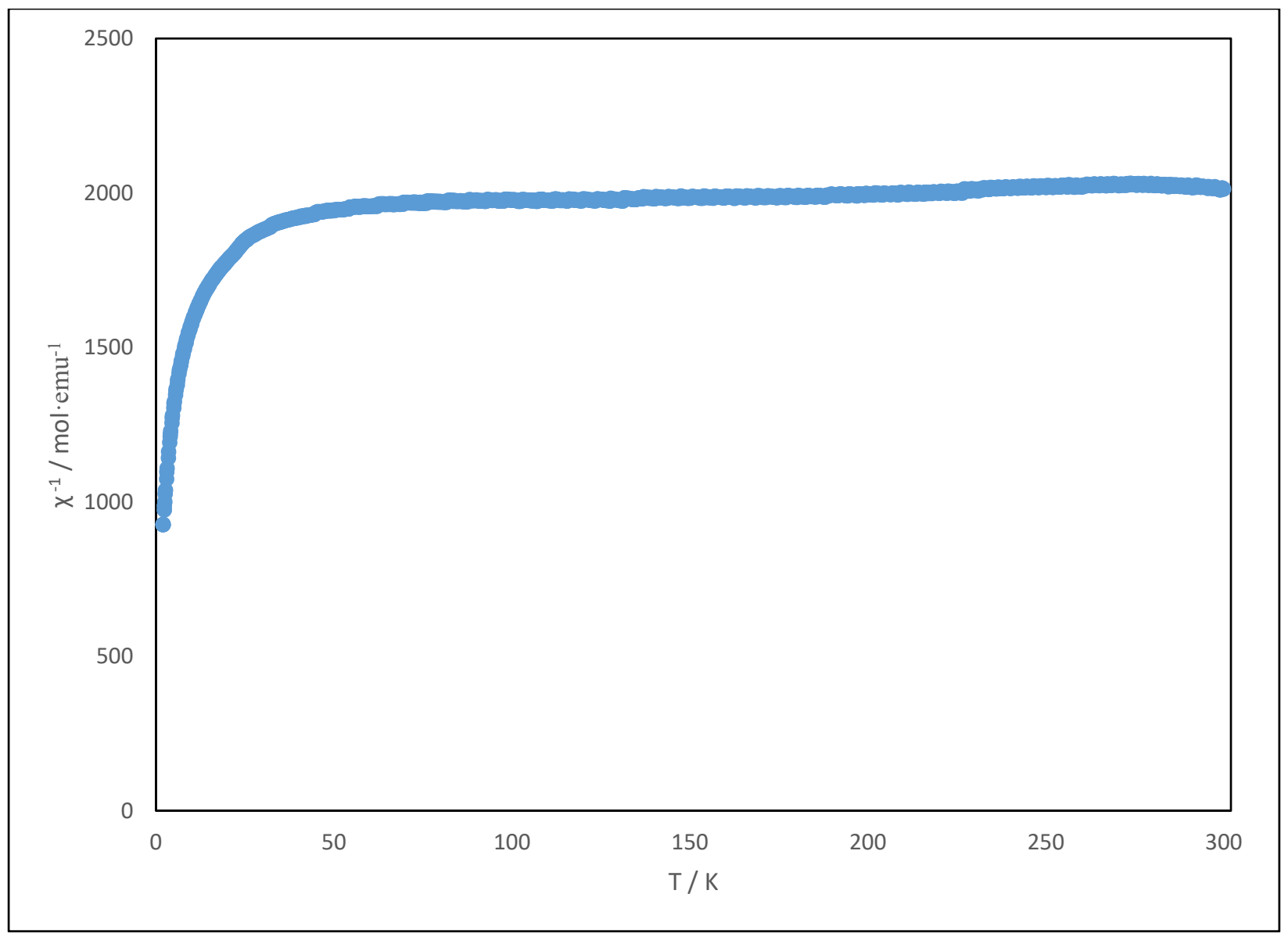

Figure S33. Variable-temperature magnetic susceptibility $(1 / \chi)$ data for 1 collected at 1 Tesla. 


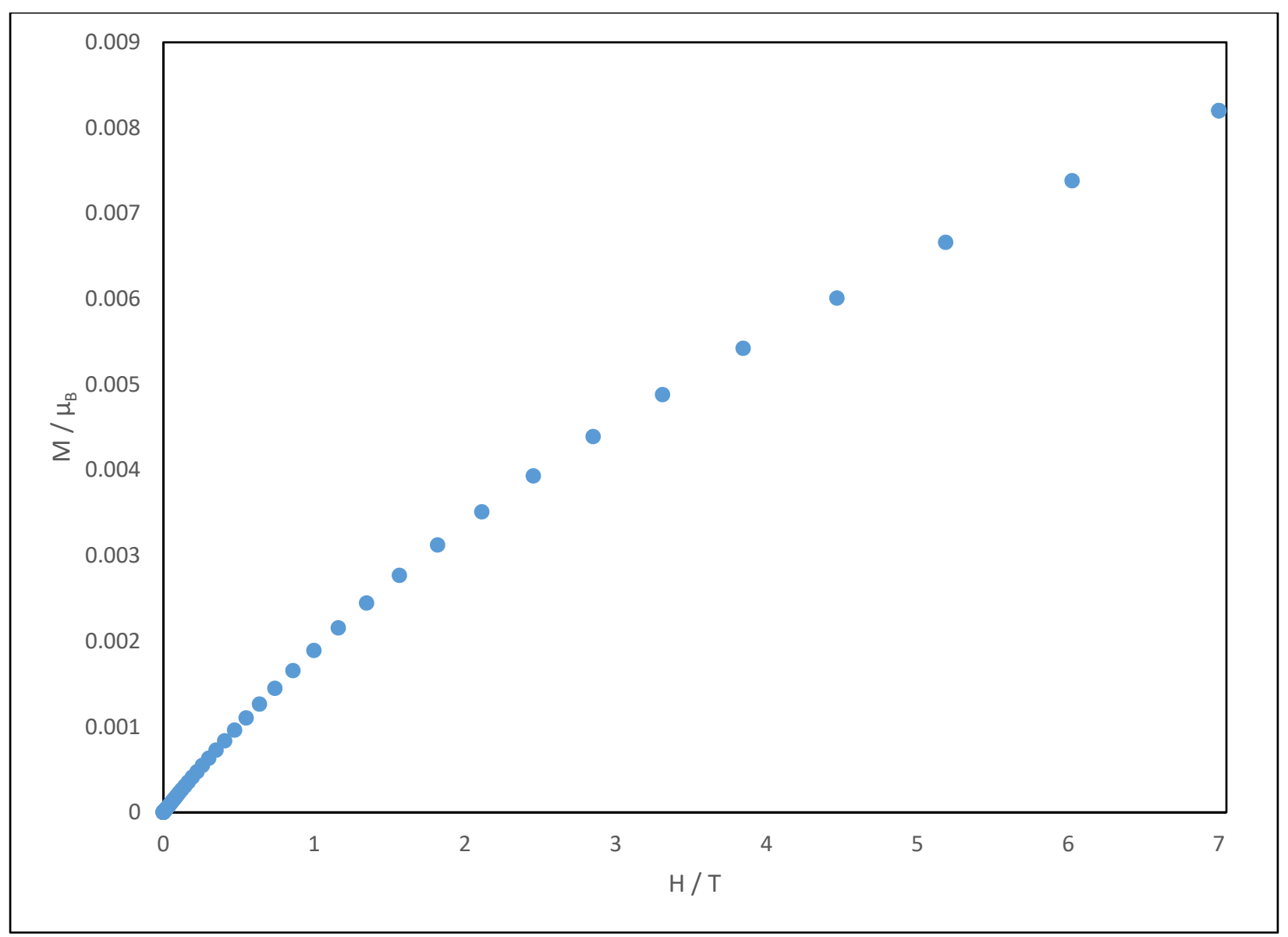

Figure S34. Variable-field data for 1 collected at $2 \mathrm{~K}$. 


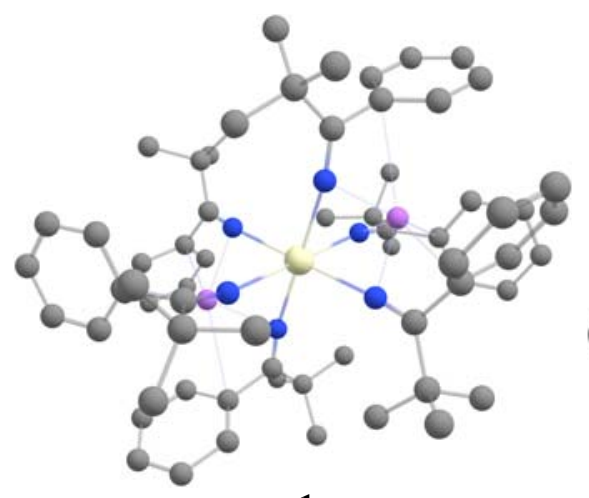

1

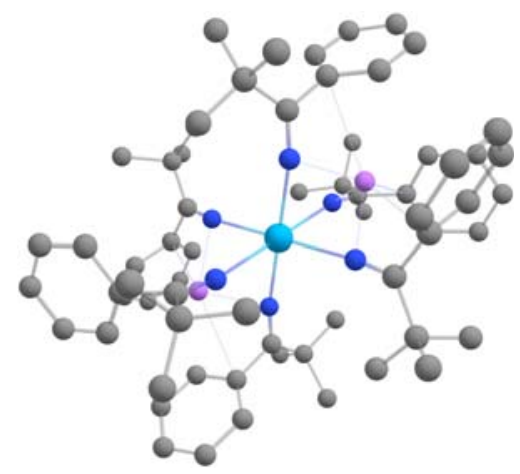

2

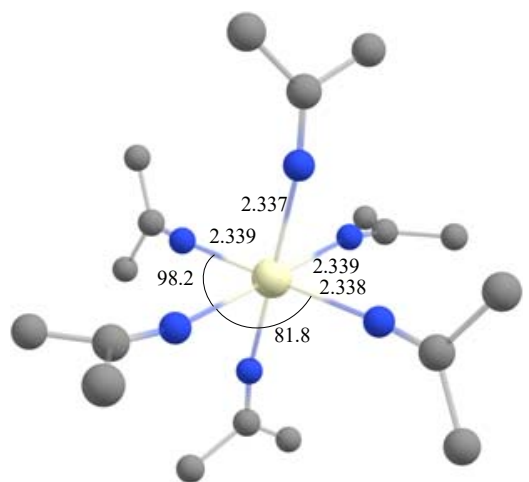

t1, $C_{1}$

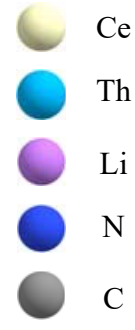

$\mathrm{C}$

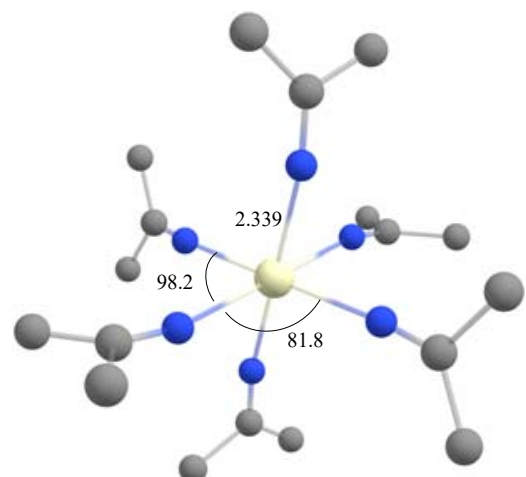

t1, $C_{\mathrm{i}}$

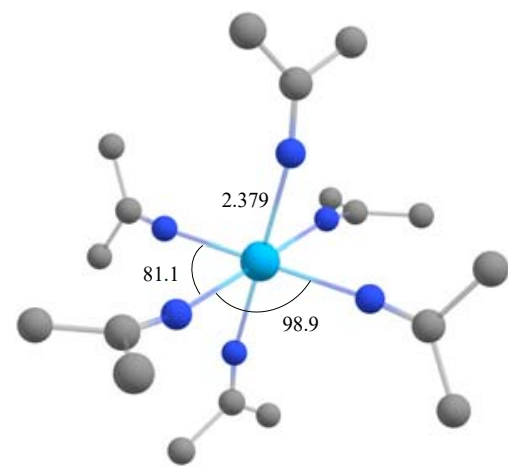

$\mathbf{t 2}, C_{\mathrm{i}}$

Figure S35. 'Ball and stick' representation of the molecular structures of $\mathbf{1}$ and $\mathbf{2}$ and of truncated (t) structures obtained from 1 and $\mathbf{2}$ by replacing the terminal butyl and phenyl groups by methyl groups and removal of the $\mathrm{Li}$ atoms $(\mathbf{t 1}, \mathbf{t} 2)$. Structure t1 was further symmetrized to the $C_{\mathrm{i}}$ symmetry point group. Selected metrical parameters (bond lengths in $\AA$, bond angles in degrees) are given for $\mathbf{t} 1$ (for both the $C_{1}$ and $C_{\mathrm{i}}$ structures to highlight the resemblance between them) and t2. Hydrogen atoms were removed for clarity. 
t1

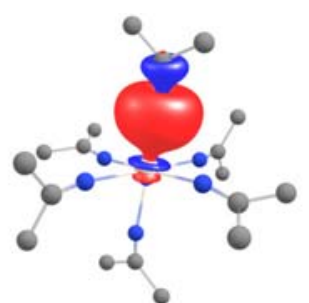

$\sigma(\mathrm{Ce}-\mathrm{N})$

def2-TZVP/SDD
$88 \% \mathrm{~N}(55 \mathrm{~s} ; 45 \mathrm{p})$

$11 \% \mathrm{Ce}(17 \mathrm{~s} ; 55 \mathrm{~d} ; 28 \mathrm{f})$

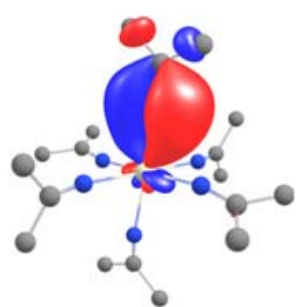

$\pi(\mathrm{Ce}-\mathrm{N})$

$81 \% \mathrm{~N}(100 \mathrm{p})$

$10 \% \mathrm{Ce}(48 \mathrm{~d} ; 52 \mathrm{f})$

Figure S36. Bonding $\mathrm{Ce}-\mathrm{N}$ (one $\sigma$ and one $\pi$ ) natural localized molecular orbitals (isosurface of \pm 0.03 a.u.) of t1, obtained with Gaussian type orbital (GTO) basis sets. The $\pi$ NLMO has slight five-center character, i.e., there is a small delocalization tail toward the carbon end of the Ce-N-C unit and adjacent C(methyl) centers. Only NLMO contributions from $\mathrm{Ce}$ and $\mathrm{N}$ centers are shown below. There are six equivalent such NLMO pairs corresponding to the six Ce-N bonds. 
RAS1

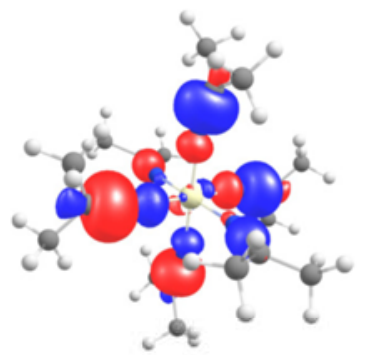

$6 \times \sigma(\mathrm{N}-\mathrm{C})$

1.988

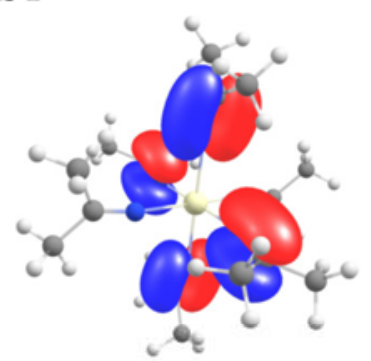

$6 \times \pi(\mathrm{N}-\mathrm{C})$

1.966

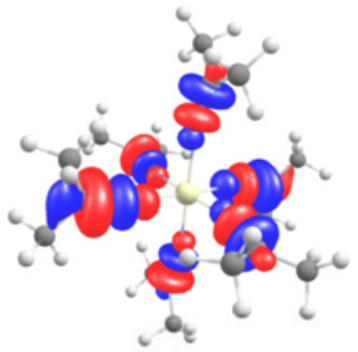

$6 \times \sigma^{*}(\mathrm{~N}-\mathrm{C})$

0.012
RAS3

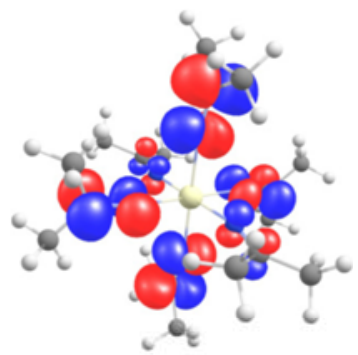

$6 \times \pi^{*}(\mathrm{~N}-\mathrm{C})$

0.034

RAS2
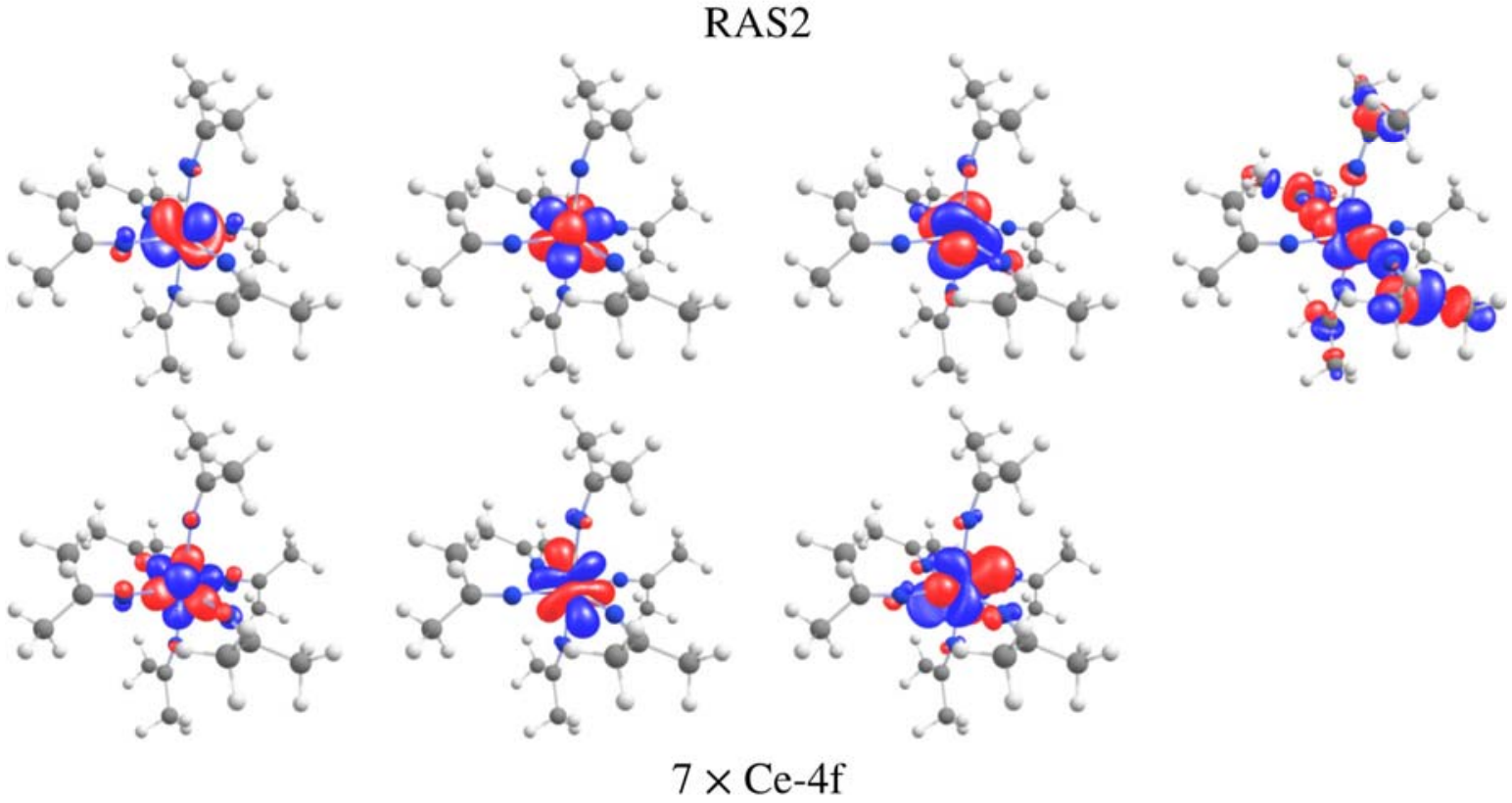

0.00

Figure S37. Active space natural orbital (NO) isosurfaces ( \pm 0.03 a.u.) and corresponding occupancies obtained from RAS calculations on the truncated complex t1. The closed-shell configuration carries $86 \%$ weight in the ground state RAS wavefunction. 
$\underline{\lambda=686 \mathrm{~nm}, \mathrm{f}=0.008}$
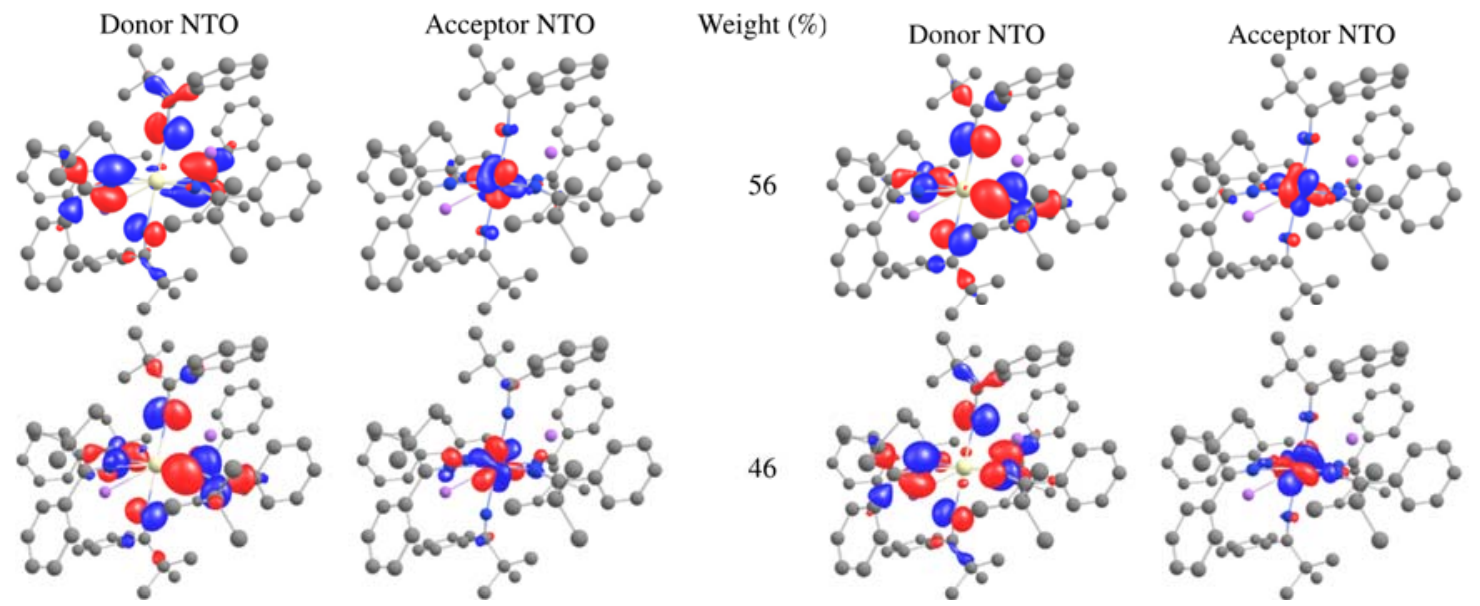

Weight (\%)

$\underline{\lambda}=671 \mathrm{~nm}, \mathrm{f}=0.016$

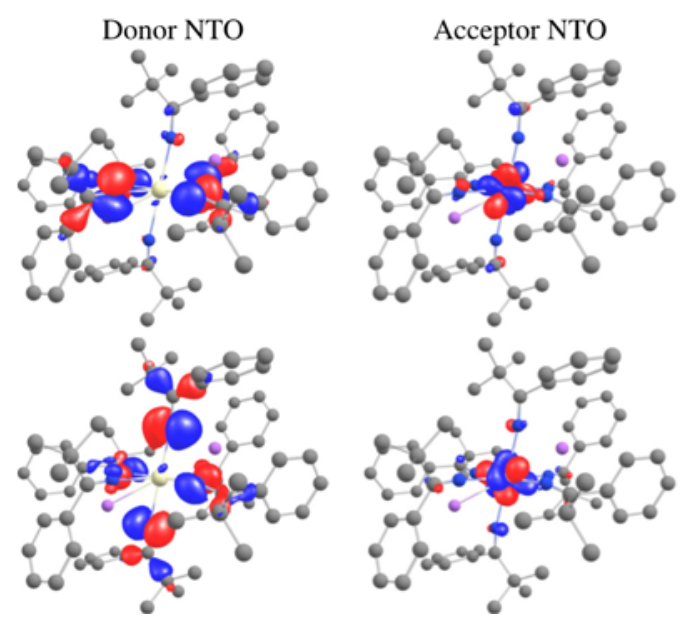

Weight (\%)

50

47

$\underline{\lambda=601 \mathrm{~nm}, \mathrm{f}=0.015}$

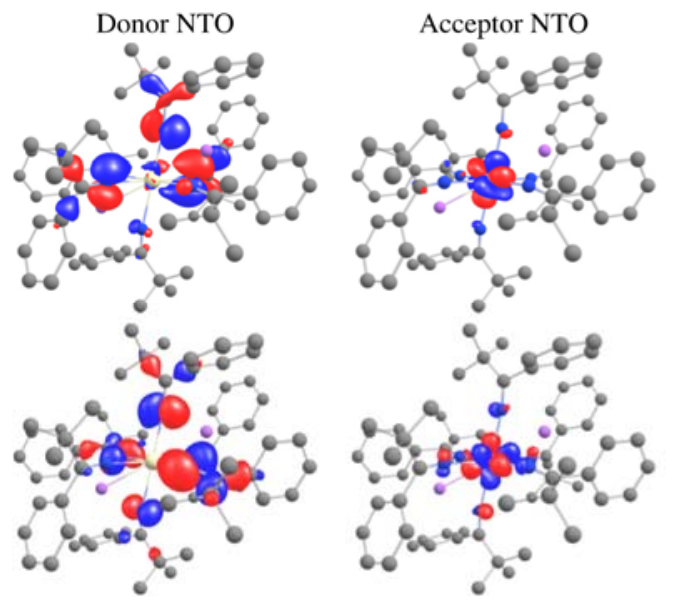

Weight (\%)

$\underline{\lambda=602 \mathrm{~nm}, \mathrm{f}=0.015}$

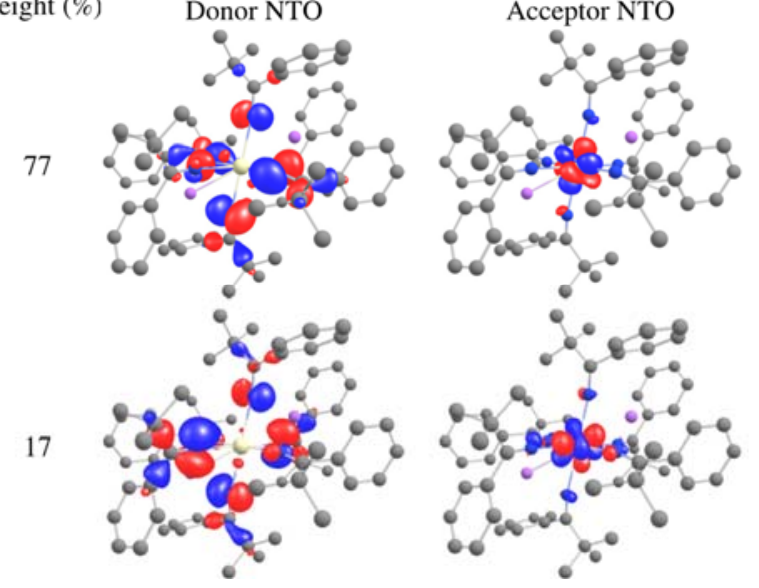

Weight (\%) 
$\underline{\lambda=579 \mathrm{~nm}, \mathrm{f}=0.013}$

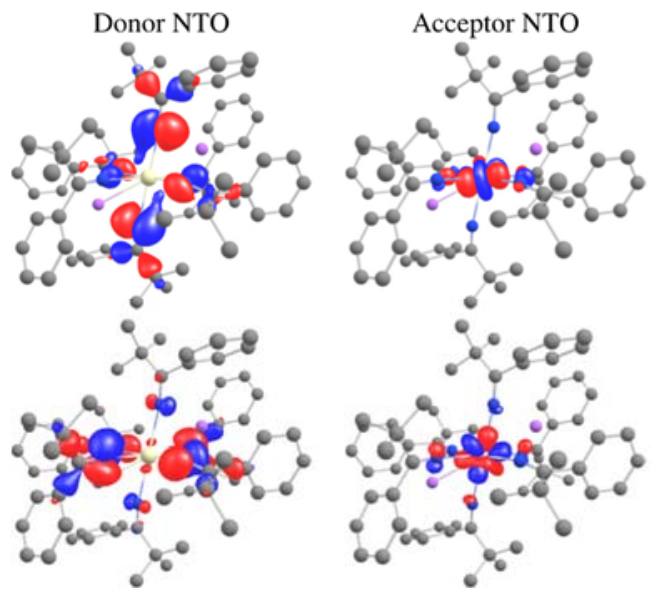

$\underline{\lambda=552 \mathrm{~nm}, \mathrm{f}=0.051}$

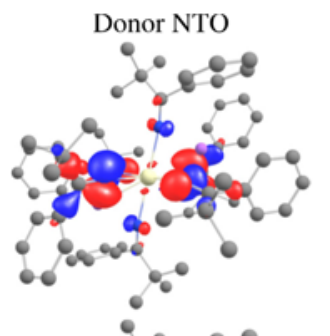

- نㅇ:-

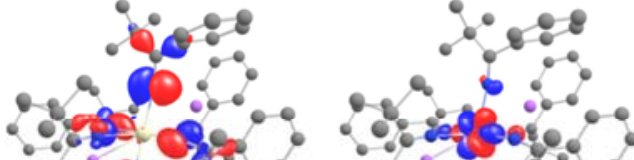
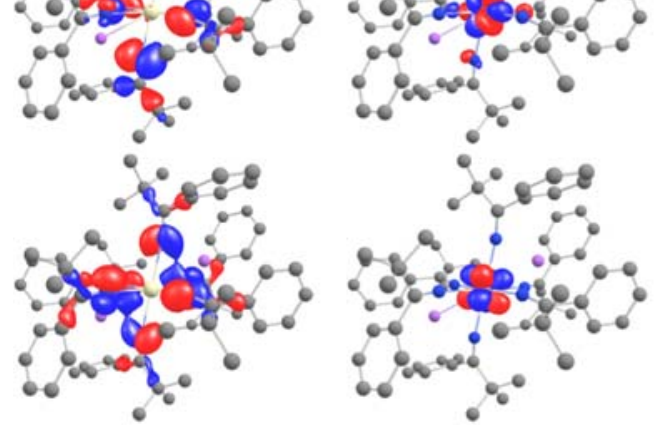

$\underline{\lambda}=516 \mathrm{~nm}, \mathrm{f}=0.047$
Donor NTO

- $8=8$

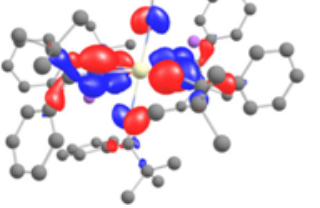

Acceptor NTO

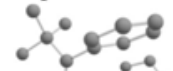

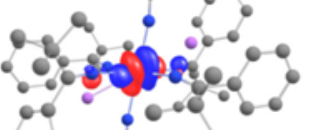
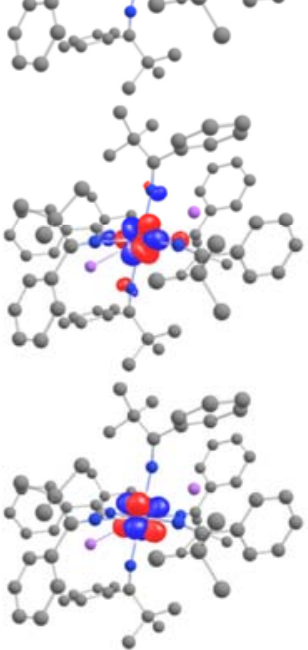

37

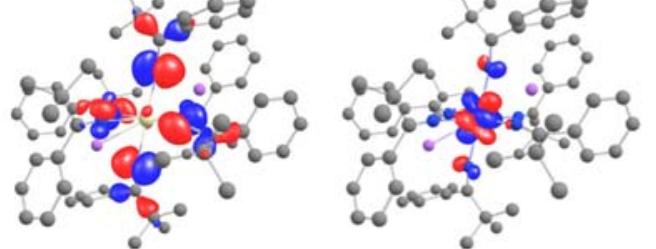

$\underline{\lambda=566 \mathrm{~nm}, \mathrm{f}=0.012}$

Weight (\%)

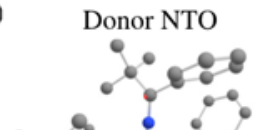

59

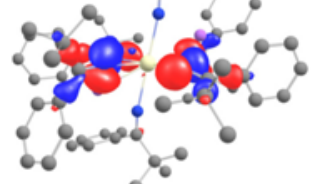

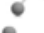

โดำ

a co: :

20
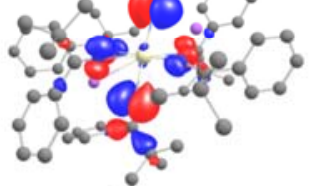

20:-8

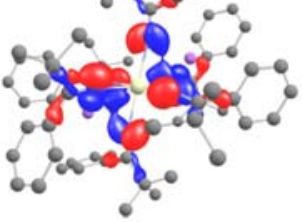

Acceptor NTO

으요

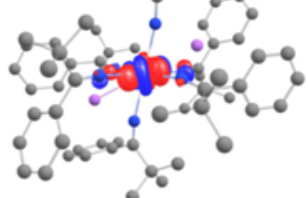

72

$\underline{\lambda}=516 \mathrm{~nm}, \mathrm{f}=0.047$

Weight (\%)

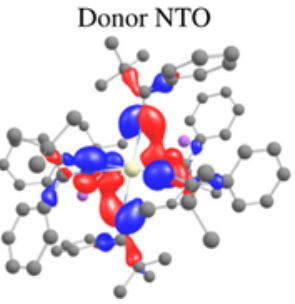

Acceptor NTO

Weight (\%)

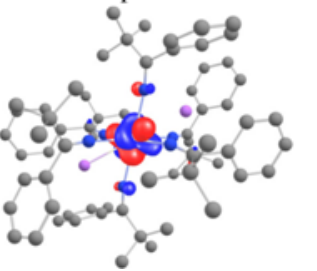



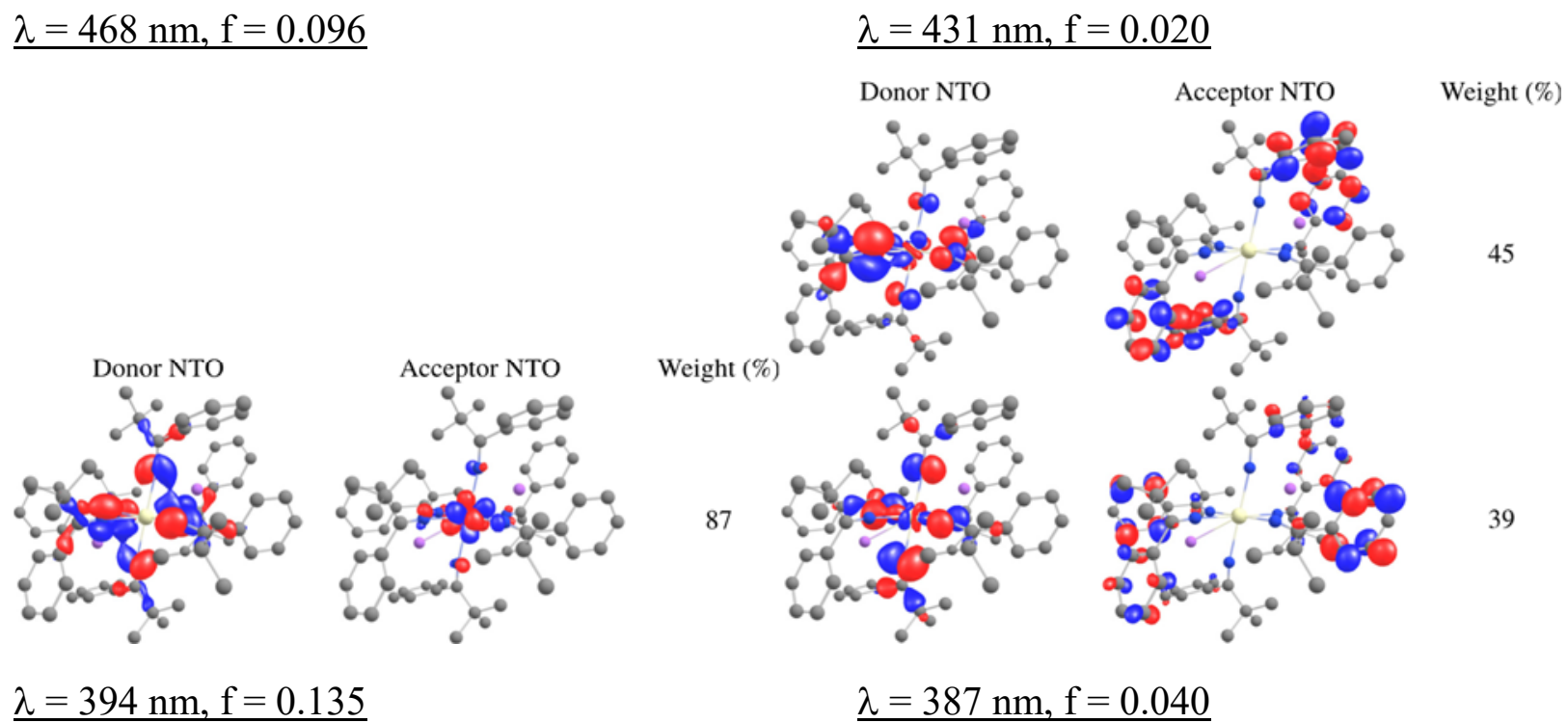

$\underline{\lambda=394 \mathrm{~nm}, \mathrm{f}=0.135}$

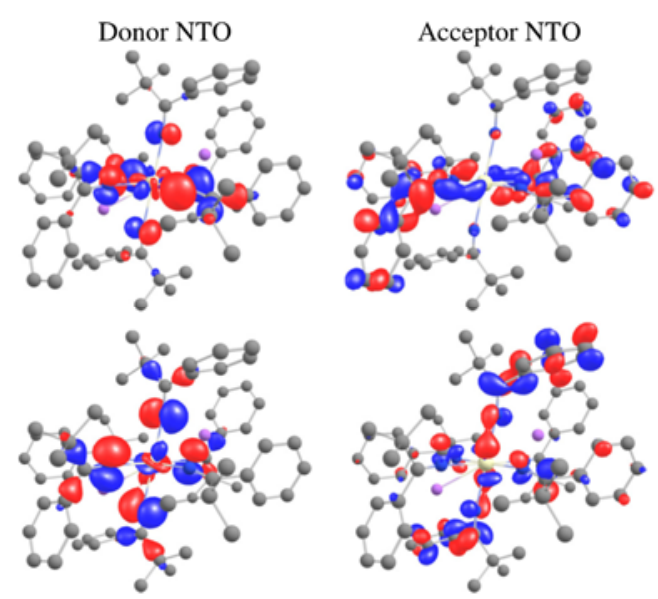

Weight (\%)

53
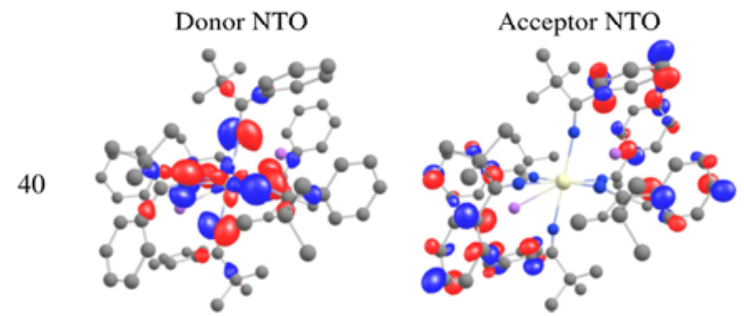

Weight $(\%)$

$\underline{\lambda=376 \mathrm{~nm}, \mathrm{f}=0.038}$
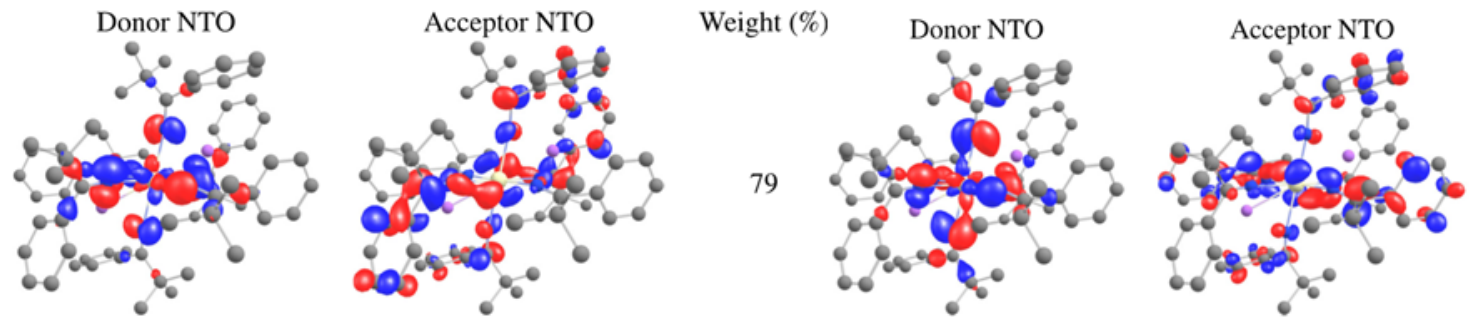

Weight (\%)

Figure S38. Natural transition orbital (NTO) analysis for 1 in the $\sim 300-800 \mathrm{~nm}$ absorption spectral region showing that at the long wavelengths the dipole-intense transitions are due to $\mathrm{N}-2 \mathrm{p}$ (lone pair) $\rightarrow$ Ce- $4 \mathrm{f}$ transitions whereas, at shorter wavelengths (below $\sim 450 \mathrm{~nm}$ ), the dipole intense transitions are due to $\mathrm{N}-2 \mathrm{p}$ (lone pair) $\rightarrow$ phenyl $\left(\pi^{*}\right) / \mathrm{C}-\mathrm{N}\left(\pi^{*}\right)$ transitions. The oscillator strengths (f) are given in length representation. 


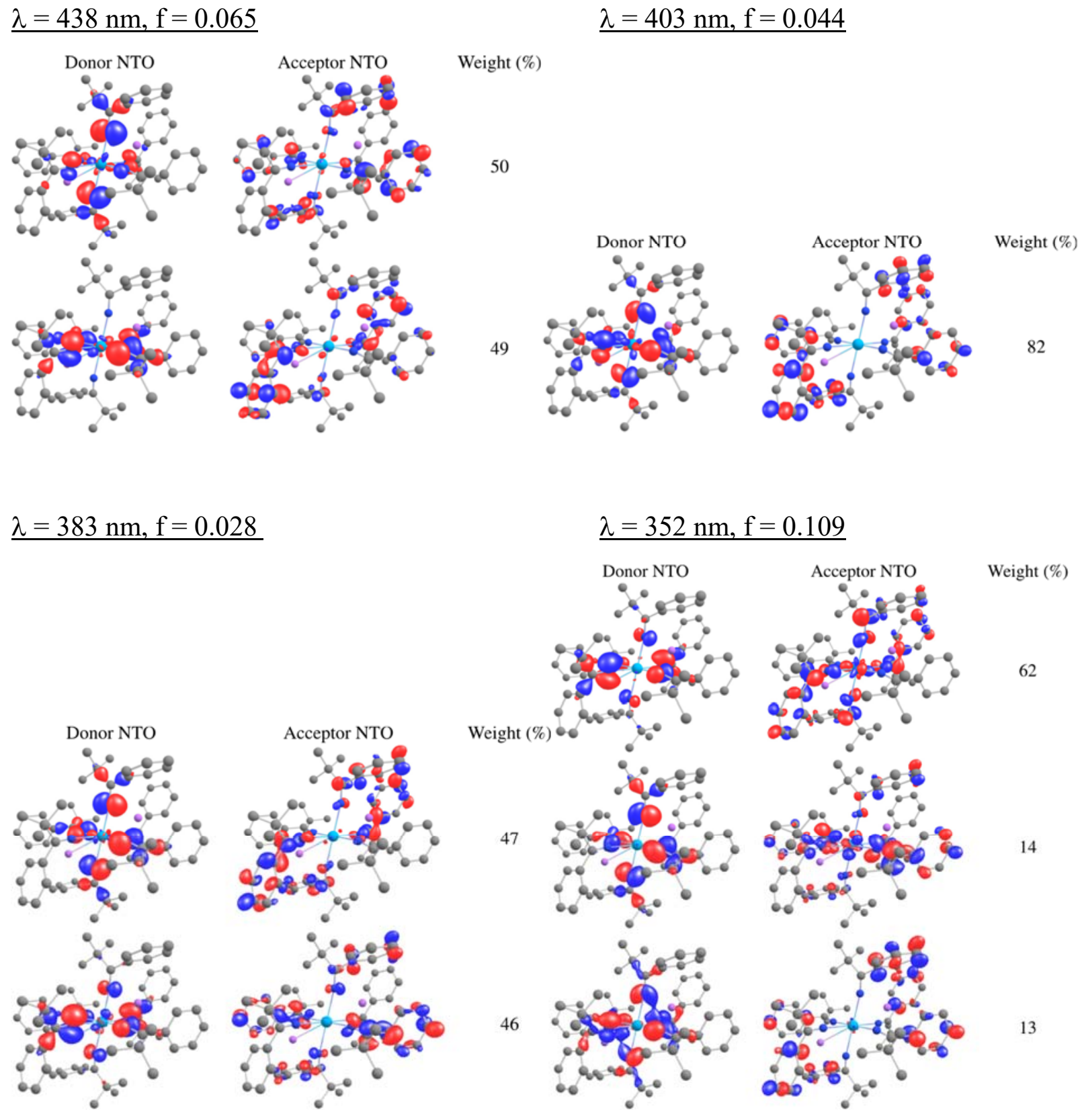



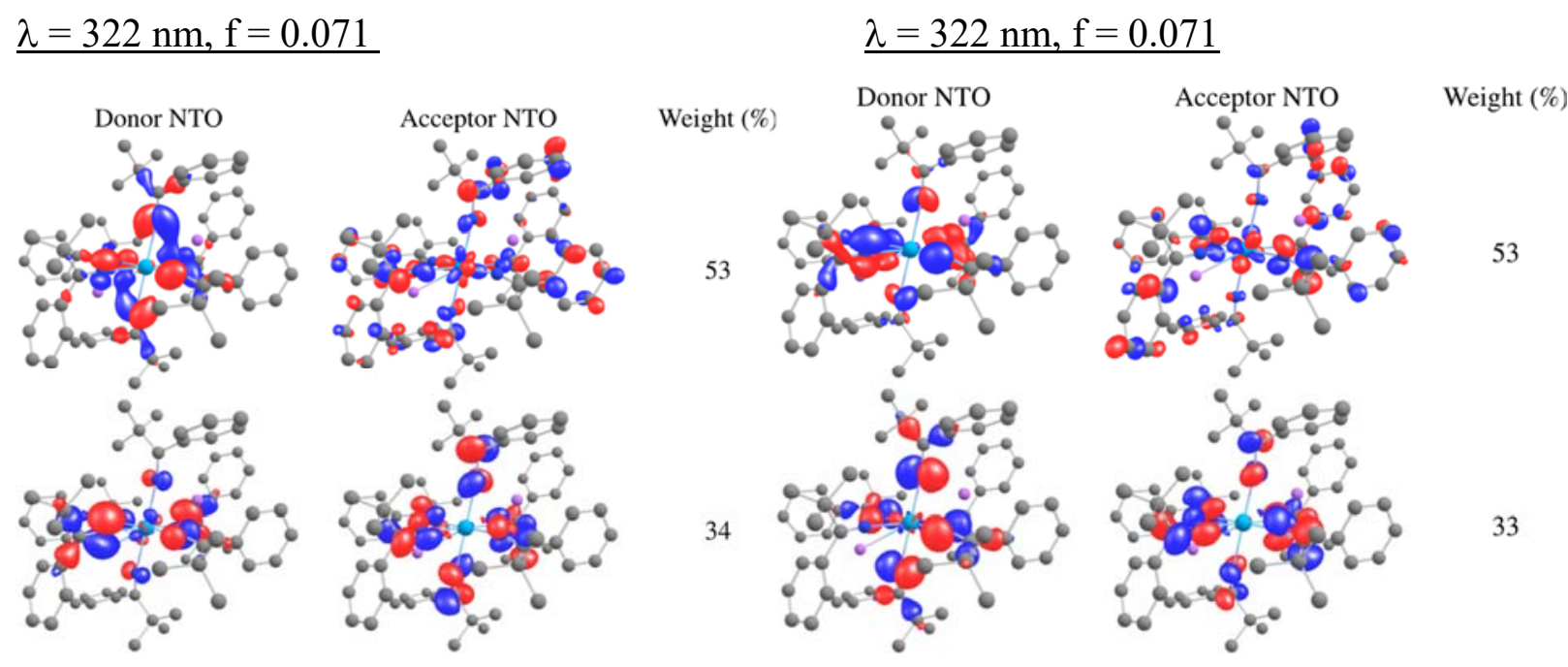

$\underline{\lambda}=302 \mathrm{~nm}, \mathrm{f}=0.143$
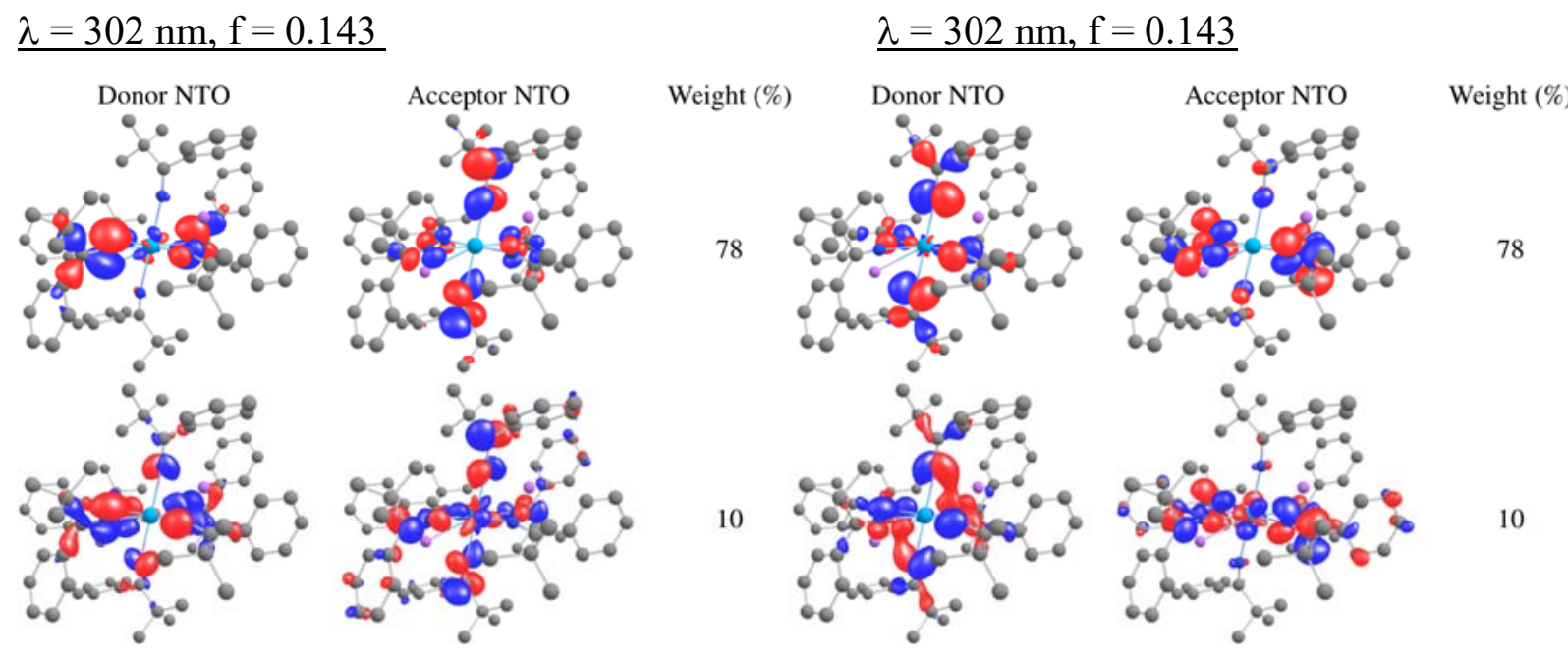

Figure S39. Natural transition orbital (NTO) analysis for complex 2 showing that the most dipoleintense transitions appearing below $\sim 450 \mathrm{~nm}$ in the absorption spectrum are due to $\mathrm{N}-2 \mathrm{p}$ (lone pair) $\rightarrow$ phenyl $\left(\pi^{*}\right)+\mathrm{N}-\mathrm{C}\left(\pi^{*}\right)$ transitions. The oscillator strengths (f) are given in length representation. 


\section{References.}

(1) Niemeyer, M. 1,2-Dimethoxyethan- und Tetrahydrofuran-Komplexe der Seltenerdmetallnitrate. Z. Anorg. Allg. Chem. 2006, 632, 1449-1456.

(2) Cantat, T.; Scott, B. L.; Kiplinger, J. L. Convenient access to the anhydrous thorium tetrachloride complexes $\mathrm{ThCl}_{4}(\mathrm{DME})_{2}$, $\mathrm{ThCl}_{4}$ (1,4-dioxane $)_{2}$ and $\mathrm{ThCl}_{4}(\mathrm{THF})_{3.5}$ using commercially available and inexpensive starting materials. Chem. Commun. 2010, 46, 919-921.

(3) Armstrong, D. R.; Barr, D.; Snaith, R.; Clegg, W.; Mulvey, R. E.; Wade, K.; Reed, D. The ring-stacking principle in organolithium chemistry: its development through the isolation and crystal structures of hexameric iminolithium clusters $\left(R R^{\prime} C=N L i\right)_{6}\left(R^{\prime}=P h, R=B u^{t}\right.$ or $M e_{2} N ; R=R^{\prime}=M e_{2} N$ or $\left.\mathrm{Bu}^{\mathrm{t}}\right)$. J. Chem. Soc., Dalton Trans. 1987, 1071-1081.

(4) Harris, R. K.; Becker, E. D.; Cabral De Menezes, S. M.; Goodfellow, R.; Granger, P. NMR Nomenclature. Nuclear Spin Properties and Conventions for Chemical Shifts. Pure Appl. Chem. 2001, 73, 1795-1818.

(5) Harris, R. K.; Becker, E. D.; Cabral De Menezes, S. M.; Granger, P.; Hoffman, R. E.; Zilm, K. W. Further Conventions for NMR Shielding and Chemical Shifts. Pure Appl. Chem. 2008, 80, 59-84.

(6) SMART Apex II. Version 2.1 ed.; Bruker AXS Inc.: Madison, WI, 2005.

(7) SAINT Software User's Guide. Version 7.34a ed.; Bruker AXS Inc.: Madison, WI, 2005.

(8) Sheldrick, G. M.: SADABS. University of Gottingen, Germany, 2005.

(9) SHELXTL PC. Version 6.12 ed.; Bruker AXS Inc.: Madison, WI, 2005.

(10) Bain, G. A.; Berry, J. F. Diamagnetic Corrections and Pascal's Constants. J. Chem. Educ. $2008,85,532$.

(11) Malmqvist, P. A.; Rendell, A.; Roos, B. O. The restricted active space self-consistent-field method, implemented with a split graph unitary group approach. J. Phys. Chem. 1990, 94, 5477-5482.

(12) Tao, J.; Perdew, J. P.; Staroverov, V. N.; Scuseria, G. E. Climbing the Density Functional Ladder: Nonempirical Meta--Generalized Gradient Approximation Designed for Molecules and Solids. Phys. Rev. Lett. 2003, 91, 146401.

(13) Neese, F. The ORCA program system. Wiley Interdiscip. Rev. Comput. Mol. Sci. 2012, 2, 73-78.

(14) Neese, F. Software update: the ORCA program system, version 4.0. Wiley Interdiscip. Rev. Comput. Mol. Sci. 2018, 8, e1327.

(15) Bergner, A.; Dolg, M.; Küchle, W.; Stoll, H.; Preuß, H. Ab initio energy-adjusted pseudopotentials for elements of groups 13-17. Mol. Phys. 1993, 80, 1431-1441.

(16) Dolg, M.; Stoll, H.; Preuss, H. Energy-adjusted ab initio pseudopotentials for the rare earth elements. J. Chem. Phys. 1989, 90, 1730-1734.

(17) Küchle, W.; Dolg, M.; Stoll, H.; Preuss, H. Energy-adjusted pseudopotentials for the actinides. Parameter sets and test calculations for thorium and thorium monoxide. J. Chem. Phys. 1994, $100,7535-7542$.

(18) Cao, X.; Dolg, M.; Stoll, H. Valence basis sets for relativistic energy-consistent small-core actinide pseudopotentials. J. Chem. Phys. 2003, 118, 487-496.

(19) Weigend, F.; Ahlrichs, R. Balanced basis sets of split valence, triple zeta valence and quadruple zeta valence quality for $\mathrm{H}$ to Rn: Design and assessment of accuracy. Phys. Chem. Chem. Phys. 2005, 7, 3297-3305.

(20) Schuchardt, K. L.; Didier, B. T.; Elsethagen, T.; Sun, L.; Gurumoorthi, V.; Chase, J.; Li, J.; Windus, T. L. Basis Set Exchange: A Community Database for Computational Sciences. J. Chem. Inf. Model. 2007, 47, 1045-1052.

(21) Stoychev, G. L.; Auer, A. A.; Neese, F. Automatic Generation of Auxiliary Basis Sets. J. Chem. Theory Comput. 2017, 13, 554-562. 
(22) Baerends, E. J.; Ziegler, T.; Atkins, A. J.; Autschbach, J.; Baseggio, O.; Bashford, D.; Bérces, A.; Bickelhaupt, F. M.; Bo, C.; Boerrigter, P. M.; Cavallo, L.; Daul, C.; Chong, D. P.; Chulhai, D. V.; Deng, L.; Dickson, R. M.; Dieterich, J. M.; Ellis, D. E.; Faassen, M. v.; Fan, L.; Fischer, T. H.; Guerra, C. F.; Franchini, M.; Ghysels, A.; Giammona, A.; Gisbergen, S. J. A. v.; Goez, A.; Götz, A. W.; Groeneveld, J. A.; Gritsenko, O. V.; Grüning, M.; Gusarov, S.; Harris, F. E.; Hoek, P. v. d.; Hu, Z.; Jacob, C. R.; Jacobsen, H.; Jensen, L.; Joubert, L.; Kaminski, J. W.; Kessel, G. v.; König, C.; Kootstra, F.; Kovalenko, A.; Krykunov, M. V.; Lenthe, E. v.; McCormack, D. A.; Michalak, A.; Mitoraj, M.; Morton, S. M.; Neugebauer, J.; Nicu, V. P.; Noodleman, L.; Osinga, V. P.; Patchkovskii, S.; Pavanello, M.; Peeples, C. A.; Philipsen, P. H. T.; Post, D.; Pye, C. C.; Ramanantoanina, H.; Ramos, P.; Ravenek, W.; Rodríguez, J. I.; Ros, P.; Rüger, R.; Schipper, P. R. T.; Schlüns, D.; Schoot, H. v.; Schreckenbach, G.; Seldenthuis, J. S.; Seth, M.; Snijders, J. G.; Solà, M.; Stener, M.; Swart, M.; Swerhone, D.; Tognetti, V.; Velde, G. t.; Vernooijs, P.; Versluis, L.; Visscher, L.; Visser, O.; Wang, F.; Wesolowski, T. A.; Wezenbeek, E. M. v.; Wiesenekker, G.; Wolff, S. K.; Woo, T. K.; Yakovlev, A. L.: Amsterdam Density Functional. 2017 ed.; SCM, Theoretical Chemistry, Vrije Universiteit Amsterdam, The Netherlands, 2017.

(23) Lenthe, E. v.; Baerends, E. J.; Snijders, J. G. Relativistic regular two-component Hamiltonians. J. Chem. Phys. 1993, 99, 4597-4610.

(24) Glendening, E. D.; Landis, C. R.; Weinhold, F. NBO 6.0: Natural bond orbital analysis program. J. Comput. Chem. 2013, 34, 1429-1437.

(25) Hirata, S.; Head-Gordon, M. Time-dependent density functional theory within the Tamm-Dancoff approximation. Chem. Phys. Lett. 1999, 314, 291-299.

(26) Barone, V.; Cossi, M. Quantum Calculation of Molecular Energies and Energy Gradients in Solution by a Conductor Solvent Model. J. Phys. Chem. A 1998, 102, 1995-2001.

(27) Cossi, M.; Rega, N.; Scalmani, G.; Barone, V. Energies, structures, and electronic properties of molecules in solution with the C-PCM solvation model. J. Comput. Chem. 2003, 24, 669681.

(28) Martin, R. L. Natural transition orbitals. J. Chem. Phys. 2003, 118, 4775-4777.

(29) Aquilante, F.; Autschbach, J.; Carlson, R. K.; Chibotaru, L. F.; Delcey, M. G.; De Vico, L.; Fdez. Galván, I.; Ferré, N.; Frutos, L. M.; Gagliardi, L.; Garavelli, M.; Giussani, A.; Hoyer, C. E.; Li Manni, G.; Lischka, H.; Ma, D.; Malmqvist, P. Å.; Müller, T.; Nenov, A.; Olivucci, M.; Pedersen, T. B.; Peng, D.; Plasser, F.; Pritchard, B.; Reiher, M.; Rivalta, I.; Schapiro, I.; Segarra-Martí, J.; Stenrup, M.; Truhlar, D. G.; Ungur, L.; Valentini, A.; Vancoillie, S.; Veryazov, V.; Vysotskiy, V. P.; Weingart, O.; Zapata, F.; Lindh, R. Molcas 8: New capabilities for multiconfigurational quantum chemical calculations across the periodic table. J. Comput. Chem. 2016, 37, 506-541.

(30) Douglas, M.; Kroll, N. M. Quantum electrodynamical corrections to the fine structure of helium. Ann. Physics 1974, 82, 89-155.

(31) Hess, B. A. Applicability of the no-pair equation with free-particle projection operators to atomic and molecular structure calculations. Phys. Rev. A 1985, 32, 756-763.

(32) Hess, B. A. Relativistic electronic-structure calculations employing a two-component nopair formalism with external-field projection operators. Phys. Rev. A 1986, 33, 3742-3748.

(33) Wolf, A.; Reiher, M.; Hess, B. A. The generalized Douglas-Kroll transformation. J. Chem. Phys. 2002, 117, 9215-9226.

(34) Aquilante, F.; Lindh, R.; Pedersen, T. B. Unbiased auxiliary basis sets for accurate twoelectron integral approximations. J. Chem. Phys. 2007, 127, 114107.

(35) Gregson, M.; Lu, E.; Tuna, F.; McInnes, E. J. L.; Hennig, C.; Scheinost, A. C.; McMaster, J.; Lewis, W.; Blake, A. J.; Kerridge, A.; Liddle, S. T. Emergence of comparable covalency in isostructural cerium(iv)- and uranium(iv)-carbon multiple bonds. Chem. Sci. 2016, 7, 3286-3297. 